UNIVERSIDADE DE SÃO PAULO

ESCOLA DE ENFERMAGEM DE RIBEIRÃO PRETO

CAMILA SOUZA DE ALMEIDA

DETERMINANTES INTRAPESSOAIS E INTERPESSOAIS DO PROCESSO

DE RECAÍDA EM USUÁRIOS DE CRACK

Ribeirão Preto 


\section{DETERMINANTES INTRAPESSOAIS E INTERPESSOAIS DO PROCESSO DE RECAÍDA EM USUÁRIOS DE CRACK}

Dissertação apresentada a Escola de Enfermagem de Ribeirão Preto da Universidade de São Paulo, para a obtenção do título de mestre em ciências, Programa Enfermagem Psiquiátrica

Linha de pesquisa: Uso e abuso de álcool e drogas

Orientadora: Profa Dra. Margarita Antonia Villar Luis

Ribeirão Preto 
AUTORIZO A REPRODUÇÃO E DIVULGAÇÃO TOTAL OU PARCIAL DESTE TRABALHO, POR QUALQUER MEIO CONVENCIONAL OU ELETRÔNICO, PARA FINS DE ESTUDO E PESQUISA, DESDE QUE CITADA A FONTE

\section{FICHA CATALOGRÁFICA}

Catalogação na Publicação

Departamento de Enfermagem Psiquiátrica e Ciências Humanas

Escola de Enfermagem de Ribeirão Preto da Universidade de São Paulo

\section{Almeida, Camila Souza de}

Determinantes intrapessoais e interpessoais do processo de recaída em usuários de crack- 2015

$106 f,:$ II : $30 \mathrm{~cm}$

Dissertação (Mestrado) - Departamento de Enfermagem Psiquiátrica e

Ciências Humanas da Escola de Enfermagem de Ribeirão Preto da Universidade de São Paulo.

1 Recaída. 2.Cocaína Crack. 3. Enfermagem. 
Nome: ALMEIDA, Camila Souza de

Título: Determinantes intrapessoais e interpessoais do processo de recaída em usuários de crack

Dissertação apresentada a Escola de Enfermagem de Ribeirão Preto da Universidade de São Paulo, para a obtenção do título de mestre em ciências, Programa Enfermagem Psiquiátrica

Aprovada em:

Banca Examinadora

Prof. Dr.

Instituição:

Julgamento:

Assinatura:

Prof. Dr. Instituição:

Julgamento:

Assinatura:

Prof. Dr. Instituição:

Julgamento: Assinatura: 


\section{DEDICATÓRIA}

Dedico este trabalho a minha família e amigos, por serem meu porto seguro 


\section{AGRADECIMENTOS}

Agradeço primeiramente a Deus e meus guardiões por mais essa etapa conquistada em minha vida, meus pais, Silvania e Pedro, por terem me dado a oportunidade de seguir meus sonhos, mesmo quando aparentavam distantes e impossíveis. Minha família por estar ao meu lado sendo um suporte e refúgio! Meus primos por tantos momentos de risadas e de aprendizagem.

A minha querida professora Nadja Lappann Botti por ter me apresentado a saúde mental e todos os seus encantos, o que me fez hoje ser uma amante dessa área.

Aos meus amigos, em especial a "Enfermáfia" (Ana Luiza, Isadora, Letícia, Laura, Samuel, Luis Gustavo, Stela e Cíntia) e André por ter compartilhado os melhores e piores momentos dessa caminhada!

Aos amigos de Ribeirão Preto, meu muito obrigada por terem complementado minha vida e por todas as risadas e momentos inesquecíveis. Ao Mateus por ter ficado ao meu lado apesar da distância, estresse e tudo mais que uma dissertação de mestrado pode trazer.

E por fim e não menos importante a Professora Margarita Antonia Luis Villar por ter me aceito como orientanda e ter dividido comigo um pouco de seu vasto conhecimento, obrigada pelos puxões de orelha e por ter confiado em mim nessa trajetória.

A todos que passaram por minha vida nesses longo e aparente curto tempo meu agradecimento e a estrada segue... 


\section{EPÍGRAFE}

Há um tempo em que é preciso abandonar as roupas usadas ... Que já têm a forma do nosso corpo ... E esquecer os nossos caminhos que nos levam sempre aos mesmos lugares ...

É o tempo da travessia ... E se não ousarmos fazê-la ... Teremos ficado ... para sempre ... À margem de nós mesmos... 


\section{RESUMO}

SOUZA, C.S de. Determinantes intrapessoais e interpessoais do processo de recaída em usuários de crack. 2015.106f. Dissertação (mestrado) - Escola de enfermagem, Universidade de São Paulo, São Paulo, 2015.

O crack, subproduto da cocaína, introduzida na década de 80 no Brasil, é um potente estimulador do Sistema Nervoso Central (SNC), desde a sua introdução no país, verificou-se que os efeitos no convívio social e familiar do usuário são quase imediatos, levando a sociedade e o estado a terem uma preocupação maior com o seu uso e controle. Devido à magnitude dos efeitos da abstinência das substâncias psicoativas (no caso o crack), a recaída apareceu como um fator comum no cotidiano dos usuários, para analisar esse fato se propôs na década de 70 um modelo de tratamento denominado Prevenção de Recaída (PR), baseado no modelo compensatório (Terapia cognitivo-comportamental) em que não há julgamento ou atribuição de culpa ao indivíduo pelo uso da droga, mas o leva à reflexão sobre seus atos e a se responsabilizar pelas mudanças de comportamento. Assim o objetivo desse estudo foi identificar os determinantes intrapessoais e interpessoais do processo de recaída em usuários de crack, além de identificar o perfil sociodemográfico, o inicio do uso e padrão de uso de crack e outras drogas (lícitas e ilícitas). Trata-se de um estudo qualitativo de teor descritivo. A pesquisa ocorreu em um CAPS ad II em uma cidade do interior de Minas Gerais e a amostra foi de conveniência. Foram realizadas entrevistas semi- estruturas em duas etapas, com intervalo de três meses cada uma com os mesmos participantes, foi aplicada a análise de conteúdo no tratamento dos dados qualitativos. Os dados sociodemográficos concordaram com a literatura nacional; exceto no que tange a média de idade. $\mathrm{O}$ início do consumo de drogas ocorreu com o uso de drogas lícitas na adolescência e a relação dos usuários de crack com as demais SPA (lícitas e ilícitas) mostrou-se ambivalente, não sendo reconhecidas como "drogas", particularmente o álcool, percebido também como gatilho ou porta de entrada para o uso do crack, já as recaídas apareceram atreladas a fatores intrapessoais e interpessoais, sendo que eles se retroalimentam, criando um círculo vicioso. O estudo mostrou que, no atendimento ao usuário de crack deve-se trabalhar com todas as facetas do uso ou do motivo da recaída, e identificar juntamente com o usuário, os gatilhos de recaída e a rede de apoio de que dispõe, fortalecendo-o na busca de mecanismos de autocontrole do uso.

Descritores: Recaída. Cocaína Crack. Enfermagem. 


\begin{abstract}
SOUZA, C.S de. Intrapersonal and interpersonal determinants of relapse process in crack users. 2015.106f. Dissertação (mestrado) - Escola de enfermagem, Universidade de São Paulo, São Paulo, 2015.

The crack, a byproduct of cocaine, introduced in the 80s in Brazil, is a potent stimulator of the central nervous system (CNS), since its introduction in the country, it was found that the effects on social and family life of the user are almost immediate, leading the society and the state to have a major concern with its use and control. Due to the magnitude of the effects of abstinence 1 of psychoactive substances (in this case crack), relapse appeared as a common factor in the daily lives of users, to analyze this fact was proposed in the 70's a model of treatment called Relapse Prevention (RP) based on the compensatory model (cognitive behavioral therapy) in which there is no judgment or blaming the individual for drug use, but leads to reflection on their actions and take responsibility for behavior change. Therefore the aim of this study was to identify intrapersonal and interpersonal determinants of relapse process in crack users, and identify the sociodemographic profile, the start of use and crack cocaine use pattern and other drugs (licit and illicit). This is a qualitative study of descriptive content. The research took place in a CAPS II ad in a city in Minas Gerais and the sample was a convenience. Semi-structures interviews were conducted in two stages, with an interval of three months each with the same participants were given the content analysis in the treatment of qualitative data. Socio-demographic data agreed with the national literature; except with respect to mean age. The start of drug use occurred with the use of illicit drugs in adolescence and crack users compared with other SPA (legal and illegal) proved to be ambivalent, not being recognized as "drugs", particularly alcohol use has also noticed as a trigger or gateway to crack use, since relapses appeared linked to intrapersonal and interpersonal factors, and they feed back, creating a vicious circle. The study showed that, in the care of crack users must work with all aspects of the use or reason of relapse, and identify with the user, the relapse triggers and the support network available to it, strengthening it in the pursuit of selfcontrol mechanisms usage.
\end{abstract}

Descriptors: Relapse. Cocaine Crack. Nursing. 


\section{RESUMEN}

SOUZA, C.S de. Determinantes intrapersonales e interpersonales del proceso de recaída en los consumidores de crack.. 2015.106f. Dissertação (mestrado) - Escola de enfermagem, Universidade de São Paulo, São Paulo, 2015.

El crack, un subproducto de la cocaína, introducida en los años 80 en Brasil, es un potente estimulador del sistema nervioso central (SNC), desde su introducción en el país, se encontró que los efectos en la vida social y familiar de los usuarios son casi inmediatos, lo que lleva a la sociedad y el Estado tenga una preocupación importante con su uso y control. Debido a la magnitud de los efectos de la abstinencia de sustancias psicoactivas (en caso de que el crack), la recidiva apareció como un factor común en la vida cotidiana de los usuarios, para analizar este hecho se propuso en los años 70 un modelo de tratamiento llamado Prevención de Recaídas (RP) basado en el modelo de compensación (terapia cognitivo-conductual) en el que no hay juicio o culpar a la persona por el uso de drogas, sino que conduce a la reflexión sobre sus acciones y asumir la responsabilidad por el cambio de comportamiento. Así que el objetivo de este estudio fue identificar los factores determinantes intrapersonales e interpersonales del proceso de recaída en los consumidores de crack, e identificar el perfil sociodemográfico, el inicio del funcionamiento y el crack patrón de consumo de cocaína y otras drogas (legales e ilegales). Se trata de un estudio cualitativo de contenido descriptivo. La investigación se llevó a cabo en un CAPS II anuncio en una ciudad de Minas Gerais y la muestra era una conveniencia. Semiestructuradas entrevistas se llevaron a cabo en dos etapas, con un intervalo de tres meses respectivamente con los mismos participantes se les dio el análisis contenido en el tratamiento de los datos cualitativos. Datos sociodemográficos de acuerdo con la literatura nacional; excepto con respecto a la media de edad. El inicio del consumo de drogas se produjo con el uso de drogas ilícitas en la adolescencia y el crack usuarios en comparación con otros SPA (legal e ilegal) resultó ser ambivalente, no ser reconocido como "drogas", en particular el consumo de alcohol también se ha notado como un disparador o puerta de entrada al crack, ya que las recaídas aparecían vinculadas a factores intrapersonales e interpersonales, y retroalimentar, creando un círculo vicioso. El estudio mostró que, en el cuidado de los consumidores de crack debe trabajar con todas las facetas de la utilización o la recaída de la razón, y se identifican con el usuario, los factores desencadenantes de recaídas y la red de apoyo a su alcance, su fortalecimiento en la búsqueda de mecanismos de autocontrol uso.

Descreptores: Recaída. Crack. Enfermería. 


\section{LISTA DE QUADROS}

Quadro 1 - Dados sócios- demográficos dos entrevistados

Quadro 2 - Motivos do uso de Substâncias psicoativas

$-42,43,44$

Quadro 3 - Expectativas em relação a substância psicoativa $-45,46$

Quadro 4 - Autoeficácia $49,50,51$

Quadro 5 - Abstinência $-52,53$

Quadro 6 - Estratégias de enfrentamento $-54,55$

Quadro 7 - Possibilidade de manutenção do prazer do uso $-56,57$

Quadro 8 - Autopercepção $-58,59$

Quadro 9 - Percepção sobre a opinião alheia $-60,61,62$

Quadro 10 - Percepção sobre as fontes de apoio tidas como suficientes $-63,64$

Quadro 11 - Percepção sobre as fontes de apoio tidas como insuficientes $-64,65$

Quadro 12 - Percepção dos participantes sobre amizade $-66,67$ 


\section{LISTA DE TABELAS}

Tabela 1 - Uso de crack e cocaína antes do início do tratamento. Minas Gerais, 2013------- 47

Tabela 2 - Uso de outras substâncias psicoativas antes do inicio do tratamento. Minas Gerais,

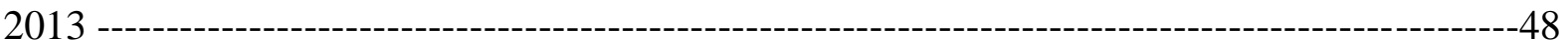




\section{LISTA DE SIGLAS}

SPA - Substâncias psicoativas

HIV - Vírus da Imunodeficiência Humana

AIDS - Síndrome da Imunodeficiência Adquirida

CAPS - Centro de Atenção Psicossocial

SNC - Sistema Nervoso Central

DSM-V - Manual Diagnóstico e Estatístico de Transtornos Mentais, quinta edição

PR - Prevenção de Recaída

USP - Universidade de São Paulo

TSH - Treinamento de Habilidades Sociais

CAPS ad II - Centro de atenção psicossocial de álcool e drogas tipo dois

SSQ - Questionário de suporte social

TCLE - termo de consentimento livre e esclarecido

NA - Narcóticos Anônimos

AA - Alcoólatras Anônimos

ESFs - Estratégia de saúde da Família

CID X - A Classificação Internacional de Doenças e Problemas Relacionados à Saúde, décima edição 


\section{SUMARIO}

1.INTRODUÇÃO

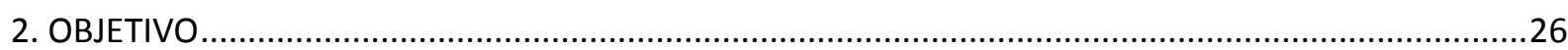

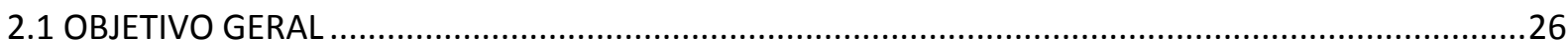

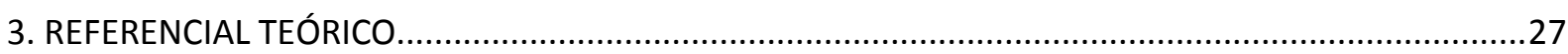

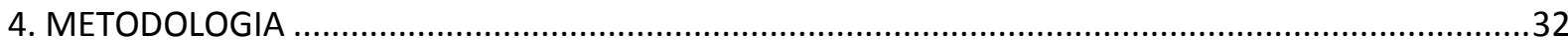

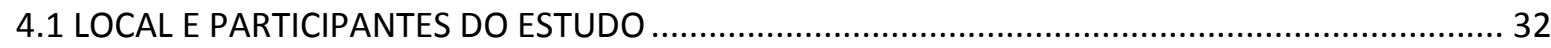

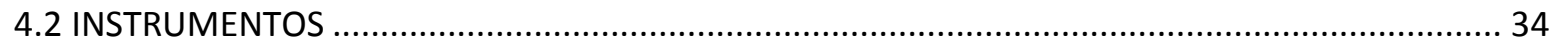

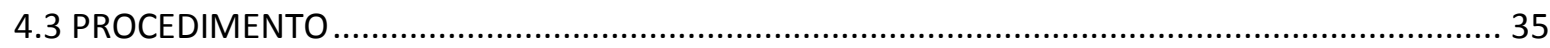

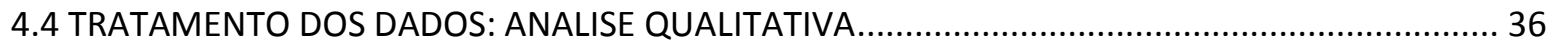

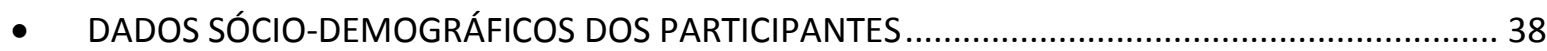

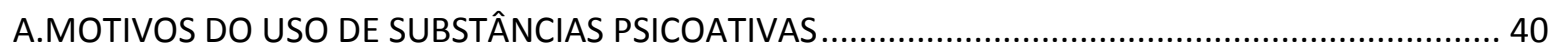

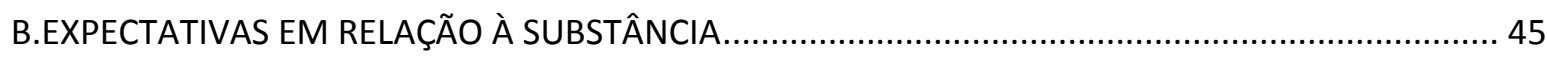

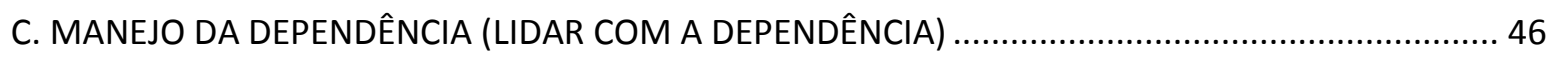

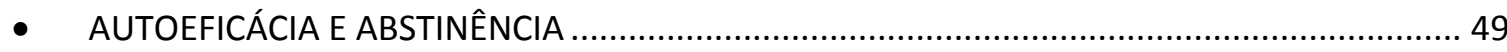

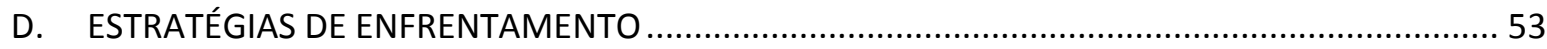

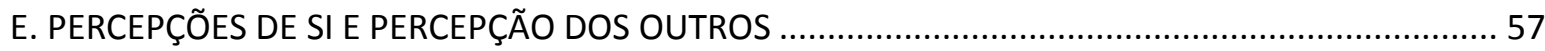

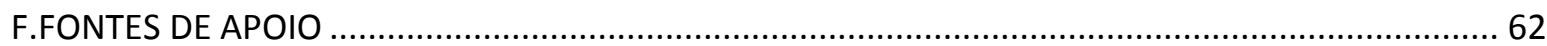

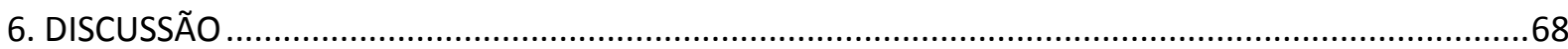

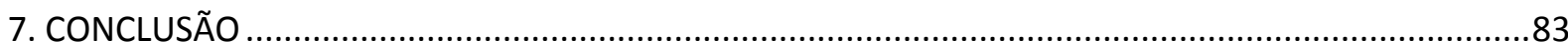

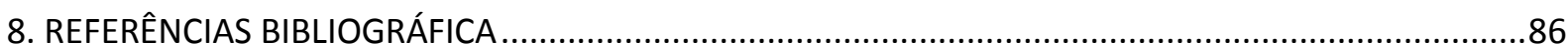

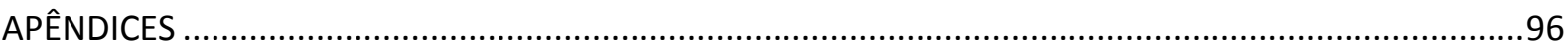

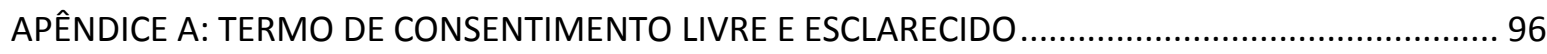

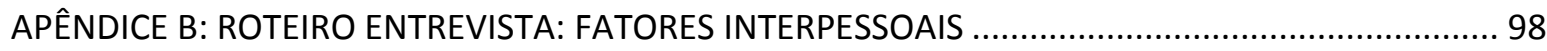

APÊNDICE C: ROTEIRO DE ENTREVISTA: FATORES INTRAPESSOAIS (MARLATT; WITKIEWITZ, 2009)

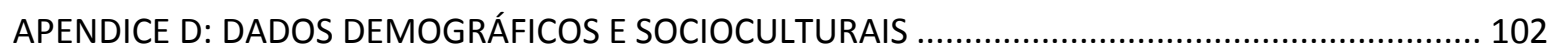

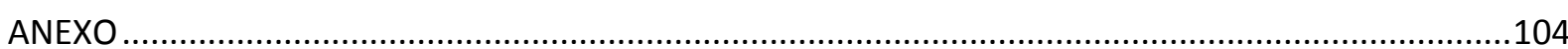

ANEXO 1- AUTORIZAÇÃO DA EER/USP PARA A REALIZAÇÃO DA PESQUISA .................................... 104

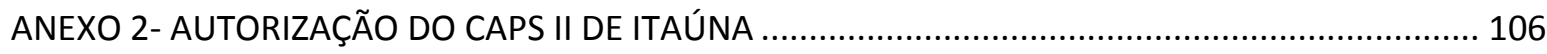




\section{INTRODUÇÃO}

O consumo de substâncias psicoativas (SPA) está inserido na história da humanidade desde os seus primórdios. Tal consumo visava à alteração do comportamento e da cognição para assim facilitar e proporcionar a conexão com as entidades místicas (CARVALHO et al, 2011; PRATTA; SANTOS,2009). Assim o uso nessa época era ligado a rituais e festas tribais por pequenos grupos de pessoas (SILVA et al,2010; PRATTA; SANTOS,2009). Esse uso era de caráter criterioso e controlado, sendo utilizado apenas em quantidades específicas o que reduzia a chance de abuso da substância (MAGALHÃES; SILVA, 2010; SILVA JUNIOR; MONTEIRO, 2012).

No decorrer dos séculos ocorreu a disseminação indiscriminada do uso de substâncias psicoativas, sendo que a única motivação para isso seria a busca do prazer, o que ultrapassa a visão ritualística ou medicinal que essas substâncias tinham em seus primórdios de uso (SILVA JUNIOR; MONTEIRO, 2012).

Estudos ou discussões acerca dos efeitos SPA são recentes, mas têm-se relatos do século XVIII, época da revolução industrial, em que se discutiam casos clínicos sobre operários que faziam uso abusivo do álcool e suas consequências para o trabalho nas fábricas (OLIVEIRA, 2011). Entende-se como abuso, o uso excessivo de alguma substância psicoativa de maneira persistente ou não, que não tenha relação com a prática médica aceita (GLOSSÁRIO DE ÁLCOOL E DROGAS, 2010).

Vale ressaltar que o aumento do consumo desse tipo de substância está atrelado a noção de lei de mercado que vem contribuindo para o aumento da produção e consumo. Assim nas últimas décadas a produção dessas substâncias passou a ser em larga escala para conseguir abastecer o mercado cada vez maior. O resultado desse uso indiscriminado é o aumento das desordens sociais e econômicas o que torna o assunto um problema tanto para a justiça quanto para a saúde pública (NEVES; MIASSO, 2010).

Em nível nacional apenas na década de 1910-1920 se iniciou a preocupação com o uso das substâncias psicoativas e assim surgiram os primeiros relatos de abuso e dependência (FILHO et al, 2003).

Quanto ao uso de crack, esse teve seu início nos Estados Unidos em meados da década de 1980, na Europa em meados dos anos 1990 e no Brasil acredita-se que tenha sido no final 
dos anos de 1980, sendo que a primeira apreensão da substância ocorreu em 1991(VARGENS; CRUZ; SANTOS, 2011; MAGALHÃES; SILVA, 2010, RODRIGUES et al,2012).

Na década de oitenta a atenção da sociedade e dos órgãos públicos estava voltada para o alastramento do vírus HIV, nessa mesma época associou-se o aumento do uso de crack por ser uma via segura em relação ao vírus da AIDS (RODRIGUES et al, 2012).

Quanto ao uso de drogas lícitas no Brasil no ano de 2012 teve-se 10,48\% dos homens usuários de álcool apresentando dependência e 3,63\% das mulheres, sendo que a taxa de prevalência dos não abstêmios (número de pessoas que consumiram álcool no último ano) chega a 50\%. A prevalência do uso de tabaco em 2012 foi de 16,9\%, sendo que o consumo é maior entre os homens com $21 \%$ da população masculina, entre as mulheres a prevalência é de 13\% (II LEVANTAMENTO NACIONAL DE ÁLCOOL E DROGAS, 2014), sendo que drogas lícitas são as que estão legalmente disponíveis por receita médica ou para compra (GLOSSÁRIO DE ÁLCOOL E DROGAS, 2010).

Já o uso de substâncias ilícitas no mundo tem sofrido um declínio ou estabilização desde a década de1990. Em 2012, 3,5\% a 7\% da população entre 15-64 relataram terem usado algum tipo de substância ilícita no ano anterior, sendo a maconha a mais utilizada (UNITED NATIONS OFFICE ON DRUGS AND CRIME, 2014).

No Brasil, a substância psicoativa mais utilizada também é a maconha, com 5,8\% da população relatando já ter feito o uso pelo menos uma vez na vida, seguida pelos solventes, anorexígeno, benzodiazepínicos e cocaína (II LEVANTAMENTO NACIONAL DE ÁLCOOL E DROGAS, 2014).

Em relação ao uso de cocaína, nas estatísticas o crack encontra-se associado como forma de uso da cocaína, estima-se que de $0,4 \%$ da população mundial a utilizaram no ano de 2012. Estima-se que 1,2\% da população da America latina tenham consumido a substância em nesse mesmo ano (UNITED NATIONS OFFICE ON DRUGS AND CRIME, 2014).

Quanto ao uso no país, a estatística mostra que 2,2\% da população na faixa etária de 15 a 59 anos já fizeram uso de alguma forma de cocaína no ano de 2012, sendo a prevalência na vida de 4,7\%. A prevalência de uso na vida de cocaína cheirada foi de 3,9\%, sendo o uso em 2012 de 1,7\%. A taxa de dependência em cocaína (cheirada) no país é de $0,6 \%$, sendo o percentual de dependência maior entre as mulheres (55\%) do que nos homens $(41,4 \%)$ (ABDALLA et al, 2014). 
Estima-se que $1,3 \%$ dos adultos já fizeram uso na vida de crack e $0,8 \%$ dos adolescentes experimentaram cocaína fumada pelo menos uma vez na vida. No ano de 2012 $0,8 \%$ dos entrevistados fizeram uso. A região sudeste do Brasil concentra em números absolutos quase a metade dos usuários de cocaína/ crack do país, com 46\% (II LEVANTEMENTO NACIONAL DE ÁLCOOL E DROGAS, 2014).

Assim como as demais substâncias psicoativas (SPA) o consumo de cocaína/ crack vem caindo em nível mundial, apenas em países emergentes se nota o aumento do consumo, o Brasil é o segundo maior mercado de cocaína do mundo e o que concentra o maior número absoluto de usuários de crack (II LEVANTAMENTO NACIONAL DE ÁLCOOL E DROGAS, 2014).

Mesmo que a substância psicoativa mais utilizada no Brasil não seja a cocaína/ crack, vê-se por parte do governo e da população uma comoção e empenho maiores para o combate dessa substância, pois ela atinge em sua maioria, jovens entre 18 e 35 anos, sendo que em média $45 \%$ dos indivíduos iniciaram o uso de cocaína antes dos 18 anos (ABDALLA et al, 2014), são em sua maioria do sexo masculino, com baixo nível escolar e causa nesses jovens sérios danos em curto prazo tanto á saúde física como a mental (PULCHEIRO et al, 2010).

Atinge em menor proporção as mulheres, mas acarreta entre elas a maior prevalência de transmissão materno fetal do HIV (CHAVES et al, 2011), violência sexual e maior prevalência para infecção por HIV, além de acarretar grande estigma e preconceito afastando- as ainda mais dos locais de ajuda, como os centros de atenção psicossociais (CAPS) e estratégia de saúde da família (ESF) e demais serviços de atenção a saúde ou a mulher (FIOCRUZ, 2014).

Esses fatos acarretam para o governo perda de mão de obra e aumento dos gastos com saúde e segurança. Já a população teme o aumento da violência, além de existir todo um clamor por parte da mídia sobre a temática (ARAÚJO et al,2010b; OLIVEIRA, 2011; SABINO; CAZENAVE,2005).

O cloridrato de cocaína é extraído das folhas da planta Erythroxylon coca, encontrada na América Latina. O crack é a transformação da cocaína pela adição de bicarbonato de sódio diluído em água (OLIVEIRA, 2011). A via de administração influência o início dos efeitos da substância, sendo quase imediato quando injetado ou fumado (CARROLL; RAWSON, 2009). A cocaína atinge o Sistema Nervoso Central (SNC) em menos de 15 segundos e ativa a liberação de dopamina e noradrenalina, que fazem parte do 
sistema de prazer e recompensa do cérebro (CARROLL; RAWSON, 2009; OLIVEIRA, 2011).

O fenômeno da neuroadaptação está presente na cocaína, com o desenvolvimento da tolerância, que seria a necessidade de se aumentar as doses da SPA consumida para conseguir alcançar os efeitos desejados (HATSUKAMI; FISHMAN, 1996). O uso crônico também pode acarretar a sensibilização, que é o aumento da atividade motora, além de comportamentos e reações de cunho paranoíde que aparecem com o uso de pequenas quantidades da droga (BEEDE; MILLMAN, 1997).

Devido ao efeito intenso e passageiro da substância se tem uma taxa de 5 a $6 \%$ dos usuários em dependência já no primeiro ano de uso da cocaína e seus derivados (CARROLL; BALL, 2010).

Os efeitos imediatos do uso dessa droga são euforia, aumento da energia, da pressão arterial e da temperatura corporal. Há ainda aumento da potência sexual, assim como da frequência respiratória. Como outros sintomas e consequências, tem-se a diminuição do apetite e da fadiga. Podem ocorrer ainda tremores, acidente vascular encefálico, ansiedade, paranoia, alucinações, dor no peito, midríase e coma, podendo levar a morte (CARROLL; RAWSON, 2009; OLIVEIRA, 2011).

A dependência química constitui um problema de Saúde Pública (CHAVES et al, 2011). Atinge vários estratos sociais e torna tanto o indivíduo envolvido quanto seus familiares alvos de violência, problemas com a justiça e comportamento sexual de risco (CHAVES et al, 2011; CARVALHO et al, 2011). A dependência inicia-se comumente com o consumo de substâncias lícitas como o tabaco e o álcool, geralmente dentro do contexto familiar. Esse uso evolui motivado pela curiosidade e a percepção de invencibilidade do jovem, para a primeira substância ilícita, geralmente a maconha. O que abre caminho para o uso de outras substâncias, sendo a cocaína/ crack a droga final de uso (SANCHEZ; NAPPO, 2002; SELEGHIM; OLIVEIRA, 2013).

Segundo o Manual Diagnóstico e Estatístico de Transtornos Mentais, quinta edição (DSM-V) a dependência química é caracterizada pelo uso de substâncias psicoativas em doses maiores que o planejado, desejo persistente de consumo, uso do tempo em atividades relacionadas à busca da substância, isolamento social, com diminuição do tempo despendido em atividades sociais, familiares ou ocupacionais, além da manutenção do consumo apesar dos prejuízos físicos acarretados pela droga, assim como a presença de fissura e tolerância (DSM- V, 2013). 
A dependência pode ocorrer quando o uso de alguma substância psicoativa é abusiva, podendo estar associada com alterações neurológicas e/ou psiquiátricas (SABINO; CAZENAVE, 2005).

A dependência ocorre devido a vários fatores, entre eles cita-se a fissura que possui papel fundamental para sua manutenção, sendo muitas vezes considerada fator decisivo para o desenvolvimento da dependência e das recaídas (CHAVES et al, 2011). Ela pode ser definida de várias formas: como um impulso para se utilizar uma substância, sendo esse impulso de caráter emergencial e forte (SANCHEZ; NAPPO, 2002) ou como um desejo subjetivo de usar a SPA (MARLATT; WITKIEWITZ, 2009). Com esta última definição pode-se inferir que a fissura pode ser componente a ser reduzido ou eliminado, bastando para isso concentrarem-se nos viesses da subjetividade do indivíduo, assim como trabalhar as expectativas de resultado (MARLATT; WITKIEWITZ, 2009).

A fissura é definida entre os usuários como sensação negativa que os compele a procurar saná-la com a busca da droga. Ela ocorre quando um sentimento ou objeto os faça lembrar-se da substância psicoativa, são as chamadas pistas internas e externas, que são geralmente relacionadas com a antecipação de um reforço positivo ou como alívio de um estado negativo, pode ocorrer também quando o indivíduo necessita sentir o prazer que a droga proporciona mais uma vez ou quando a fissura se enquadra como um dos efeitos do uso de SPA (CHAVES et al, 2011).

A fissura por cocaína causa organicamente disforia, anedonia, ansiedade, sensação de irritabilidade e fadiga, além de ideações de ruína e autoextermínio, podendo durar de dois a quatro dias chagando até mesmo há meses. Sendo que o quadro não é vital, mas deve-se tratar devido ao risco de recaída. Nesse período o sofrimento orgânico e psíquico compele o usuário a buscar a substância (FOCCHI; LEITE; SCIVOLETTO, 2001; KAPLAN; SADOCK, 1988).

Bruehl et al (2006) aponta três desencadeantes para a fissura que seriam: o ambiente que daria pistas, como por exemplo: ver alguém usando o crack ou frequentar lugares onde se fazia o uso, outro desencadeante seria a própria retirada da droga e por último a perda do efeito da substância psicoativa. Essa perda do efeito é muitas vezes referida pelos usuários de droga como uma necessidade do organismo que gera sofrimento tanto psíquico quanto físico

Para Witkiewewitz et al (2013), a fissura tem três componentes: o biológico, o afetivo e o cognitivo que são inseparáveis e que devem ser trabalhados juntos para um melhor resultado. 
Cada componente tem suas especificações, sendo que o biológico seria responsável pelos sintomas fisiológicos da abstinência (WITKIEWEWITZ et al,2013). Os sintomas da fissura ocorreriam devido a não recaptação da dopamina, que surgiria pelo uso crônico da droga, essa não recaptação diminuiria os níveis dopaminérgicos, causando uma sensibilização dos receptores e uma hipofunção desses, acarretando no indivíduo a busca constante pela SPA (WHO, 2004).

O componente afetivo estaria ligado aos afetos que podem ser positivos ou negativos, os negativos são para alguns autores como Baker, Morse e Sherman (1986) o fator mais importante para a fissura, o componente afetivo também englobaria o estresse e o grau de expectativas do indivíduo.

E por último estaria o componente cognitivo que inclui a memória, os automatismos, o grau de estresse que o individuo exterioriza e a autoeficácia (SINHA; LI, 2007).

Para diminuir a fissura são utilizadas técnicas não farmacológicas juntamente com fármacos que auxiliam na diminuição dos efeitos físicos da SPA (BANBINOT et al 2011; ARAUJO et al,2004; FOCCHI; LEITE; SCIVOLETTO, 2001), mas ainda não se tem um fármaco que atue nos múltiplos receptores da cocaína, por exemplo.

Em um estudo clínico em que se utilizaram dois grupos, em que um fez uso de um placebo e o outro de um agonista dopaminérgico como forma de se tratar a fissura por cocaína, demonstrou-se que não houve diferenças entre os dois grupos, confirmando assim que não se tem até os dias atuais um tratamento farmacológico capaz de atuar nos múltiplos neurotransmissores em que a cocaína atua (FOCCHI; LEITE; SCIVOLETTO, 2001).

O dependente seria o indivíduo para quem a droga passou a exercer papel de destaque na vida e no enfrentamento de situações sentidas como problemáticas. O problema pode ser definido de várias maneiras, como sendo um evento negativo na vida do indivíduo que acarreta danos em sua vida social e psicológica. Também se pode ver a problemática como uma vivência em que esse usuário encontra-se diante de uma realidade, seja objetiva ou subjetiva, insuportável e ao não conseguir modificá-la ou evita-la faz do uso das drogas uma alternativa (BEVAN, 2009; SABINO; CAZENAVE, 2005; SILVEIRA, 1995).

Existem linhas diferentes de pensamento que fundamentam os modelos de tratamento de usuários de substâncias psicoativas. Para alguns autores a finalidade do tratamento seria tornar o indivíduo abstêmio. Assim, o primeiro passo para a recuperação seria a abstinência. A grande dificuldade na manutenção desse modelo é a instabilidade 
emocional e a angústia que a privação da substância psicoativa causa no usuário. Muitos comparam a retirada da droga como uma ruptura com o sentido da existência, como se a vida não tivesse mais um significado. (RIGOTTO; GOMES, 2002; MATHIAS; CRUZ, 2007, RIBEIRO; LARANJEIRA, 2010).

Já a outra visão seria a da redução do uso que busca uma auto - reorganização do usuário de substâncias psicoativas como primeiro passo para a recuperação. Essa recuperação seria assim caracterizada pelo controle voluntário do consumo da substância, por uma melhora geral dos cuidados com a saúde e por um envolvimento social (MARLATT; WITKIEWITZ, 2009; HENDERSHOT, 2011). Para isso é imprescindível que o usuário esteja engajado na mudança do padrão de uso e com aumento da autoeficácia. A compreensão dos mecanismos da substância e o enfoque nos determinantes internos são cruciais para que um controle seja alcançado (DUFFY; BALDWIN, 2013).

Seguindo essa linha de pensamento criou-se a redução de danos, que tem como estratégia uma promoção de saúde alternativa que não visa necessariamente à abstinência (PASSOS; SOUZA, 2011). Compreende-se que o consumo de substâncias psicoativas faz parte do cotidiano das sociedades, existindo desde os primórdios da civilização. Assim é utópico imaginar um mundo sem essas substâncias, ainda mais que a sociedade capitalista a transfigurou em mais um produto de consumo (VELOSO; CARVALHO; SANTIAGO, 2004). Os danos que as substâncias psicoativas causam não são inerentes apenas do produto, mas estão inseridos no significado que o sujeito dá a ela (MEDEIROS et al, 2010).

Alcançar a abstinência seria o ideal, mas a recusa não deve ser empecilho para a exclusão do tratamento. Sendo que esse tem como foco a resolução dos problemas associados ao uso das substâncias psicoativas, o que pode levar o sujeito aderir à abstinência a seu próprio tempo (DIAZ et al, 2009). Segundo Passos e Souza (2011) muitos usuários quando se sentem acolhidos e inseridos no processo de cuidado tanto da sua saúde quanto da comunidade diminuem o uso da substância psicoativa ou se tornam abstinentes.

Algumas medidas ajudam nesse processo como: mudança no círculo de amizade, afastando-se principalmente dos amigos usuários, como também evitar os locais que remetem ao uso da substância (CHAVES et al, 2011; CARVALHO et al, 2011). O engajamento em projetos significativos também ajuda a preencher a lacuna deixada pela substância. Esse convívio e engajamento em novos planos levam a adaptação comportamental e recuperação da autoestima assim como da autoeficácia (RIGOTTO; GOMES, 2002). 
Assim o tratamento do usuário de crack deve levar em consideração as possíveis alterações cognitivas, psicológicas e neuronais que esse indivíduo adquiriu devido ao uso da substância e deve atender as várias necessidades desse usuário e não apenas abordar o uso das drogas. Fazendo assim com que esse consiga gerenciar e superar os déficits cognitivos, emocionais e sociais (DUFFY; BALDWIN, 2013; LARANJEIRA, 2010).

O plano de tratamento não se resume a apenas desintoxicar o paciente. Esse deve ser o início da terapêutica, para se obter sucesso o aconselhamento e outras técnicas comportamentais devem ser utilizadas (RIBEIRO; LARANJEIRA, 2010). Dentre as técnicas/ programas utilizados se tem a prevenção de recaída (PR), entrevista motivacional, treinamento de habilidades sociais (THS), tratamento de exposição a estímulos, entre outras. Esses programas devem ser utilizados em conjunto para assim aumentar a eficácia do tratamento.

Já o uso de medicamentos no caso dos usuários de crack tem como objetivo reduzir os sintomas causados pela substância, entre eles se destacam: alívio da abstinência, redução da fissura, além de atuar nas comorbidades psiquiátricas que são comuns nesses indivíduos. Com isso o indivíduo consegue focalizar e solucionar os conflitos interpessoais e intrapessoais de maneira mais eficaz (ALVES; RIBEIRO, 2010; NIDA, 2009).

O tratamento medicamentoso não ocupa lugar de destaque dentre os vários tipos de tratamento existentes e funciona com a combinação de outras técnicas. Sendo que o tratamento multidisciplinar é a melhor forma de se obter uma resposta mais completa por parte do usuário de cocaína/crack (BAGOIEN et al, 2013; DUAILIBI; RIBEIRO; LARANJEIRA, 2008).

A grande dificuldade para se tratar os usuários de crack é que dentre os indivíduos que fazem uso de substâncias psicoativas, esse é o grupo que menos procura ajuda. Postergando essa ajuda para situações agudas, em que geralmente já se tem um comprometimento psiquiátrico/ neuronal, assim esse usuário dá entrada nos serviços de saúde não devido ao problema com as substâncias psicoativas, mas sim devido à comorbidades (OPSAL et al, 2013; CARLSON et al, 2010; RIBEIRO et al, 2007).

Outro fator que se deve levar em consideração é que a grande parcela atingida pelo uso da substância é de origem socioeconômica baixa o que dificulta a percepção e o reconhecimento do grau de dependência, postergando assim a procura por tratamento (PULCHEIRO et al, 2010). 
Esse fenômeno ocorre tanto devido ao usuário de crack quanto dos familiares. Diferentemente das outras drogas, os familiares dos usuários de crack geralmente não buscam ajuda, cabendo aos próprios terem que procurar o que adia o início do tratamento (MAGALHÃES; SILVA, 2010).

Vários são os determinantes que preterem essa procura entre eles podem-se citar fatores de ordem sociocultural, Wechsberg et al (2007) em seu estudo apontou que os afrodescendentes são o grupo que menos procura os serviços de ajuda, devido às barreiras financeiras, físicas e pelo próprio receio de serem estigmatizados. As mulheres também postergam o reconhecimento do problema, em estudo Opsal et al (2013), aponta que a maioria das intervenções de cunho involuntário ocorre entre essas, entre os fatores para esse evento tem-se a maior vulnerabilidade por parte desse grupo nos quesitos de violência e prostituição.

De maneira geral os entraves para a procura de ajuda são de ordem financeira e física. Além disso, essa população muitas vezes se encontra com comorbidades e em estado deprimido complicando ainda mais a busca e a adesão ao tratamento (WECHSBER et al 2007; FALCK et al, 2004).

Alguns autores defendem que o tratamento deve ser realizado em ambientes estruturados, por profissionais que reconheçam o tipo de ajuda que esses indivíduos buscam para se tornarem abstêmios e reconstruírem suas vidas (RIBEIRO; LARANJEIRA, 2010; MAGALHÃES; SILVA, 2010). Outros estudiosos apostam em um tratamento realizado fora das clínicas e consultórios fechados, alcançando a população em seu ambiente de uso da substância psicoativa, que não é necessariamente o endereço fixo desses indivíduos. Esse programa é conhecido como consultório de rua e está incluso nas políticas do Ministério da Saúde desde o ano de 2009 (FRIEDRICH, 2012; MEDEIROS et al, 2010).

Os consultórios de rua têm como finalidade alcançar a população mais carente e vulnerável, que se encontram as margens da rede de atendimento dos serviços de saúde. Tendo como princípio a redução de danos e a substituição do modelo biomédico centrado na "cura”, ou seja, na abstinência como única finalidade do tratamento. Os consultórios de rua buscam conscientizar os usuários de substâncias psicoativas e torna-los protagonistas de sua própria história, para assim alcançarem níveis satisfatórios de saúde e inclui-los novamente na rede de atendimento a saúde (FRIEDRICH, 2012; MINISTERIO DA SAÚDE, 2010).

Seja qual for à escolha de tratamento, o que deve permear o pensamento dos profissionais de saúde é que o trabalho com dependentes de substâncias psicoativas pode se mostrar muitas vezes árduo e pouco gratificante, mas ao mesmo tempo estimulante. $\mathrm{O}$ 
profissional assim não deve demonstrar desesperança ou desespero, mas também não deve esperar progressos constantes, há de se ter a compreensão de que o processo da dependência psicoativa é uma caminhada com vários percalços pelo caminho (RANGE; MARLATT, 2008).

Os trabalhadores de saúde devem assim firmar uma aliança terapêutica, reforçando o vínculo e tentando envolver no processo toda a rede de apoio desse usuário, principalmente os familiares, já que um dos motivos que levam ao aumento da motivação por parte do indivíduo é a perspectiva de recuperação dos laços familiares. Assim reforçar o envolvimento da família é crucial para o sucesso do tratamento (DUFFY; BALDWIN, 2013; MÉIER et al, 2006).

Dentro desse leque de possibilidades de tratamento, espera-se que a enfermagem encontre seu papel já que são esses os profissionais que estão na linha de frente do cuidado. Seja na atenção básica realizando o acolhimento e intervenção breve quando necessário ou nas demais frentes de atendimento.

Em pesquisa realizada por França, Siqueira (2011) demonstrou-se que o conhecimento por parte da equipe de enfermagem dos processos de recaída, seus determinantes e terapêuticas é fator decisivo para a recuperação e manutenção da abstinência em usuários de SPA.

A educação em saúde é uma das ferramentas que devem ser usadas pela equipe, por proporcionar aos usuários dessas substâncias a aquisição de conhecimentos, atitudes e práticas pessoais que os farão analisar de maneira crítica suas atitudes, e reconhecer os gatilhos que o fazem retornar ao uso da substancia psicoativa (NAKATANI, 2010). A educação em saúde deve englobar também a família, já que essa precisa ser estimulada a modificar a condição de vulnerabilidade em que se encontra na maioria das vezes. Os encontros realizados entre várias dessas famílias ajudam no processo, uma vez que propicia a troca de experiências (MAGALHAES; SILVA, 2010). .

Assim, para que ocorra esse processo educativo, a equipe de enfermagem deve ter a iniciativa de se estruturar através de uma teoria, de oficinas de aprimoramento e reciclagem, além de se empoderar-se acerca da temática da dependência química. Importante que o plano terapêutico seja elaborado em conjunto com os demais profissionais, familiares e o próprio usuário da substância psicoativa, otimizando o percurso terapêutico (BRASIL, 1997; NAKATANI, 2010; MAGALHAES, SILVA; 2010). 
No país, a literatura existente sobre o crack está centrada nas alterações orgânicas, tráfico de drogas e as estratégias de tratamento (RODRIGUES et al, 2012), sendo que existe pouco material abordando o processo de recaída. Ainda segundo Pulcheiro et al (2010) o conhecimento Brasileiro acerca do uso de crack é insuficiente para se traçar políticas publicas sobre a temática. O que demonstra a urgência de estudos nessa área, já que o assunto é de extrema relevância quando se analisa o crack como uma substância que tem o potencial de modificar a conduta de um indivíduo, tornando-o incapaz muitas vezes de procurar por auxílio ou tratamento (DUFFY; BALDWIN, 2013; RODRIGUES et al, 2012; RIBEIRO; LARANJEIRA, 2010).

Quanto ao papel da enfermagem e sua importância no processo de recuperação de usuários de substâncias químicas, não se tem muitas pesquisas no país e quando ocorrem são relacionadas às drogas lícitas. Em pesquisas realizadas nos bancos de dados, no período do ano de 2014, sendo esses bancos a biblioteca virtual de saúde, biomed central, portal capes e pubmed não se obtiveram artigos ou relatos de caso específicos sobre o papel da enfermagem no processo de recaída de usuários de crack.

Em um país em que o consumo dessas substâncias se tornou tema central de política pública e conquistou a mídia e a atenção da população, é imprescindível que as ações que norteiam o plano nacional de combate ao crack em vigor desde 2011(BRASIL, 2011) sejam embasadas em estudos nacionais bem estruturados.

Assim há necessidade da enfermagem e demais profissionais envolver-se e desenvolver estudos que busquem aumentar o conhecimento sobre a temática, identificar o perfil desse usuário, os fatores que possam interferir em sua busca pela recuperação ou reinserção social, bem como os mecanismos da recaída, a fim de propor programas ou técnicas de intervenção a serem implementadas tanto no âmbito dos serviços de saúde quanto na comunidade.

O presente estudo pretende contribuir para o alcance dessa finalidade, pois a grande questão que se impõem nos dias atuais são as razões pelas quais os usuários de cocaína/crack mostram-se recaem logo após longos períodos de tratamento. Sendo que foi essa inquietação que motivou a realização desta pesquisa. 


\section{OBJETIVO}

\subsection{OBJETIVO GERAL}

O objetivo desse estudo foi caracterizar usuários de crack com vistas a identificar e analisar os determinantes intrapessoais e interpessoais do processo de recaída. 


\section{REFERENCIAL TEÓRICO}

$\mathrm{Na}$ década de oitenta, alguns pesquisadores de comportamentos aditivos, afastando-se do modelo de doença, estabeleceram definições mais cognitivas e comportamentais para explicar os transtornos da dependência química (MARLATT; WITKIEWITZ, 2009).

$\mathrm{Na}$ dependência química, a recaída é uma ocorrência frequente, sendo descrita como um resultado visto numa perspectiva dicotômica- a pessoa está bem ou está doente e como um processo em que houve qualquer ruptura no processo de mudança do comportamento esperado. Ocorre então, o retorno ao uso problemático da substância (WITKIEWITZ et al, 2013).

A recaída nessa perspectiva, remonta ao modelo médico, ao indicar o retorno ao estado de doença na sequência de um período de recuperação. No caso do uso das SPA, em que os indivíduos tentam modificar comportamentos problemáticos, retornos ao comportamento que pretendem controlar ou suprimir são relativamente esperados, seja na forma de lapso (uso pontual) ou recaída (MARLATT; WITKIEWITZ, 2009; WITKIEWITZ et al, 2013).

Marlatt (1978) desenvolveu no final dos anos setenta uma taxonomia com detalhes a respeito de situações consideradas como de alto risco para recaídas. A partir disso o autor propôs o primeiro modelo cognitivo- comportamental do processo de recaída, o qual se concentra na resposta de uma pessoa em situação de alto risco.

Os componentes dessa resposta pressupõe a interação entre as pessoas, incluindo a motivação, o enfrentamento, os estados emocionais a autoeficácia, a expectativa de resultado, além da fissura. Também existem os fatores de risco ambientais, que se referem às influências sociais (apoio social) e ao acesso a substâncias (MARLATT; WITKIEWITZ, 2009).

Dentro da teoria proposta por Marlatt e Witkiewitz (2009) pode-se definir recaída como a ruptura com o quadro de abstinência. Esse quadro pode ter inicio com o lapso que é caracterizado como breve momento de retorno ao comportamento anterior, que pode levar a dois possíveis resultados: o indivíduo voltar ao padrão de mudança positivo ou ter a recaída, na qual a pessoa volta a fazer uso da SPA nas mesmas quantidades ou mais (MARLATT; WITKIEWITZ, 2009). O lapso pode ser visto como um processo de aprendizagem e de reavaliação dos mecanismos de enfrentamento, o que leva a maior probabilidade do indivíduo 
voltar a um padrão de mudança positivo. Quando as situações que levaram ao lapso provêm de aspectos internos do indivíduo, ou fatores percebidos como incontroláveis a possibilidade de recaída torna-se maior (MARLATT; WITKIEWITZ, 2009; ARAÚJO et al, 2010b).

A decisão de romper ou não com a abstinência é algo mediado pelas expectativas que o usuário tem quanto aos benefícios que considera que a droga lhe proporciona (MARLATT; WITKIEWITZ, 2009; HENDERSHOT, 2011). Estudos nacionais identificaram como fatores que levam o indivíduo a romper com a abstinência, os conflitos familiares, principalmente com o parceiro (a), a manutenção da mesma rotina, ou seja, conviver com as mesmas pessoas e frequentar os mesmos locais de uso (RIGOTTO; GOMES, 2002; CARVALHO et al, 2011; ARAÚJO et al, 2011)

Outro fator apontado é a pressão social, principalmente de amigos usuários, além do uso do álcool como gatilho para a volta ao uso de crack (GABATZ et al, 2013). Importante ressaltar que esses indivíduos possuem dificuldade em lidar com frustrações, como perda de emprego, falta de recursos financeiros e discussões corriqueiras, o que consequentemente, os leva a buscar novamente a substância como meio de aplacar os sentimentos negativos (RIGOTTO; GOMES, 2002; CARVALHO et al, 2011; ARAÚJO et al, 2011).

Em seu estudo Duff e Baldwin (2013), também apontaram o medo do recebimento de salário como um fator que precipita a recaída, pois esse indivíduo muitas vezes acredita que ao recebê-lo irá usá-lo para o consumo de substâncias psicoativas. Assim, muitos que se encontram em recuperação evitam o trabalho remunerado, por um período. O estudo nacional realizado por Sanchez e Nappo (2002) corrobora com esse dado, ao apontar que o salário recebido é normalmente utilizado para o consumo de SPA.

Segundo Marllat e Witkiewitz (2009), são sete os determinantes: seis intrapessoais e um interpessoal, que podem influenciar no processo de lapso/recaída, os quais são apresentados na sequência.

Entre os intrapessoais encontra-se a autoeficácia, caracterizada como o grau de confiança que a pessoa possui em relação a sua própria capacidade de realizar certo comportamento num contexto específico. O indivíduo pode relatar autoeficácia em não consumir a substância química, mas a verdadeira avaliação vai ocorrer quando este se encontrar em um ambiente de alto risco para o consumo. Outro determinante é a expectativa de resultado, que ocorre quando o indivíduo antecipa os efeitos que espera obter em consequência do uso da substância. Essas expectativas podem ser de caráter físico, 
psicológicos ou comportamentais e nem sempre condizem com os efeitos reais do uso da droga.

As expectativas de resultado podem ainda ser de cunho positivo ou negativo. Quando positivas proporciona ao indivíduo motivação para consumir a substância química, já as expectativas negativas levam a manutenção da abstinência. A motivação pode ser consciente ou inconsciente e é definida como estímulo para uma dada ação ou objetivo. (MARLATT; WITKIEWITZ, 2009; CARROLL; BALL, 2010; HENDERSHOT, 2011).

Essa prontidão para a mudança ocorre em estágios, chamados de estágios de mudança (PROCHASKA; DICLEMENTE; NORCROSS,1992), que são:

- Estágio 1: pré- contemplação: se enquadram nesse estágio os pacientes que não consideram que o uso que fazem de álcool e drogas seja um problema, pode-se chamalos de usuários "felizes".

- Estágio 2: Contemplação: o paciente está em ambivalência, ou seja, já percebe a necessidade de mudança, mas ao mesmo tempo a rejeita.

- Estágio 3: Preparação: O paciente percebe a droga como causadora de problemas e se propõe a mudar o comportamento.

- Estágio 4: Ação: Nesse período o paciente coloca em ação planos e estratégias para a mudança do comportamento.

- Estágio 5: Manutenção: O paciente tenta manter o comportamento modificado. É nessa fase que podem ocorrer as recaídas.

Outro determinante intrapessoal é o enfrentamento, que é definido como a capacidade que o ser humano tem de usar estratégias efetivas para lidar com alguma situação de risco e tem como objetivo reduzir o risco ou conseguir gratificação em dada situação. Os estados emocionais também tem relação com o lapso \recaída, sendo que o afeto negativo (o não se sentir bem) reforça o consumo de SPA, já os estados emocionais positivos estão relacionados com a manutenção da abstinência (DECORTE, 2001). E como citado anteriormente tem-se a fissura como determinante intrapessoal que não é um indicativo de recaída, sendo necessária uma conjunção de fatores/determinantes para que essa ocorra, sendo essa um fenômeno complexo, que pode ser descrita como um impulso forte para o uso e ser desencadeado devido a sensações negativas, lembrança da droga, entre outros fatores (CHAVES et al, 2011). A fissura está inteiramente relacionada à autoeficácia, sendo que quando o indivíduo está confiante em seu controle a tendência é a diminuição da fissura (ARAUJO et al, 2011). 
Com o passar do tempo à fissura tende a diminuir, por isso é importante o acompanhamento por longa data do paciente, pois mesmo que a tendência seja a diminuição da fissura, acontecimentos de cunho negativo ou estressores podem desencadear novamente o fenômeno (DOMINGOS, 2012; RIBEIRO; LARANJEIRA, 2010).

Os determinantes interpessoais (influências sociais) também têm importância, sendo o apoio social, principalmente o de caráter positivo, responsável pelo maior tempo de abstinência. A qualidade e o tamanho da rede social podem estar relacionados à recaída, pois redes sociais em que se têm usuários de SPA podem influenciar/ pressionar o indivíduo ao uso (GABATZ et al, 2013).

O modelo proposto por Marlatt e Witkiewitz (2009) atua no sentido da prevenção de recaída (PR), baseada no modelo compensatório em que o indivíduo não é culpado pelo uso da droga, mas levado a se responsabilizar pelas mudanças de comportamento. Assim, a recuperação é vista como um processo de aprendizado, em que é possível reestruturar mudanças positivas de comportamento (MARLATT; GORDON, 1993). Utilizam-se técnicas e estratégias baseadas na avaliação inicial de situações de alto risco de recaída, como estressores ambientais e características pessoais. Uma vez identificadas essas situações, trabalham-se as habilidades de enfrentamento, as emoções negativas que levam ao uso da substância, a autoeficácia e estilo de vida do usuário. Assim o indivíduo se torna apto a prever e gerenciar os gatilhos (eventos que precedem o uso) do lapso/ recaída (BEVAN, 2009; CARROLL; RAWSON, 2009; SAKIYAMA; RIBEIRO, 2010). A PR é utilizada muitas vezes conjuntamente com a entrevista motivacional, uma vez que as técnicas não se contrapõem.

A entrevista motivacional visa aumentar a motivação, explorar a ambivalência que existe no uso das substâncias químicas, além de ampliar a visão sobre os processos de mudança. Tem como ponto chave o respeito ao tempo e motivação para a mudança de cada indivíduo. Essa técnica reduz o problema de maneira mais imediata, mas deve ser utilizada em conjunto com outro tratamento (MATHIAS; CRUZ, 2007; BAGOIEN et al, 2013; BEVAN,2009). Como recurso adicional também pode utilizar-se o treinamento de habilidades sociais (TSH). Os estudiosos Del Prette e Del Prette (2006) definem habilidade social como um conjunto de comportamentos que o individuo possui para lidar com as situações diárias e de convivência. Nessa condição se trabalharia com o indivíduo as possíveis formas de lidar com a sua realidade sem o uso da SPA.

O uso excessivo de substâncias psicoativas pelo indivíduo faz com que esse perca a habilidade de conviver em sociedade, o que prejudica possíveis tratamentos e até mesmo sua 
reinserção social. Assim o TSH leva em consideração os fatores interpessoais e intrapessoais. No treinamento das habilidades interpessoais tem-se o aprendizado do manejo de situações cotidianas, como por exemplo, saber dizer não aos amigos, ou evitar recorrer ao bar em caso de solidão ou tristeza. Dentro das habilidades intrapessoais foca-se no manejo das emoções, principalmente a raiva, que é decisiva para o quadro de recaída. O incentivo a prática de esportes e outras atividades, assim como mudanças no estilo de vida são reforçadas durante esse programa (RANGE; MARLATT,2008; SILVA; SERRA, 2004).

A exposição a estímulos é usada como coadjuvante dentro do plano terapêutico. Essa técnica tem como característica a exposição de estímulos condicionados aos usuários de substâncias psicoativas, sem que esses façam o uso da substância. A técnica visa a diminuir as respostas condicionadas de cunho fisiológico e da fissura através da extinção do comportamento (ARAÚJO et al,2010).

A prevenção de recaída tem sido utilizada no tratamento de usuários não apenas de crack, mas de outras drogas, até mesmo na dependência do tabaco e do álcool. Alguns pesquisadores testaram o modelo proposto por Marllat e Witkiewitz (2009).

Bowen et al (2009), comparou dois grupos; num ele utilizou uma técnica embasada na PR em que os sujeitos realizaram durante as sessões uma forma de meditação (expansão da mente), que os levaram a aprender a lidar com os próprios sentimentos e aceitá-los, além de aprenderem técnicas de enfrentamento para lidar com situações de angustia e conflitos, no outro grupo( grupo controle), realizou-se apenas sessões de psicoterapia. O grupo da PR mostrou resultados positivos em relação ao da psicoterapia, como diminuição da fissura e aumento das habilidades de enfrentamento, isso durante os quatro meses seguintes intervenção. Após esse período, ocorreram casos de recaída que foram avaliadas pelos autores como resposta à perda do suporte recebido inicialmente (BOWEN et al, 2009).

Outro estudo que utilizou a técnica de expansão da mente (meditação) também obteve resultados positivos em comparação aos modelos tradicionais. No estudo foram oito sessões de meditação de duas horas cada. A meditação foi vista como positiva por aumentar a autoeficácia, ao levar a pessoa a não julgar atos de outras pessoas, aceitação de seu estado de uso e consciência do problema atual (WITKIEWITZ et al, 2013). 


\section{METODOLOGIA}

A metodologia escolhida para o estudo foi a qualitativa que apresenta como foco o entendimento em profundidade dos fenômenos, seja pela observação, descrição ou análise da cultura de um determinado contexto (TURATO, 2005). O foco principal desse tipo de metodologia é conhecer a vivência da população sobre um evento (TAYLOR; BOGDAN, 1998).

Trata-se se um estudo descritivo que tem como foco o conhecimento da população alvo do estudo, estudando suas características, problemas e perfis. O estudo descritivo pretende descrever, o mais próximo possível, os fatos e fenômenos determinantes da realidade (TRIVIÑOS, 1987).

A pesquisa qualitativa requer que o pesquisador selecione os indivíduos de forma tão diversificada quanto possível, que compartilhem o fenômeno a ser estudado para se saturar de maneira satisfatória a pesquisa. Deve- se levar em consideração o recurso financeiro, a abrangência das questões e os critérios de inclusão da pesquisa (PATTON, 2002).

O estudo qualitativo utiliza-se de um conjunto de participante relativamente pequeno em que se procura aprofundar a vivência dos sujeitos em cada entrevista. A quantidade de indivíduos entrevistados não precisa ser necessariamente grande, sendo que quando se inicia a repetição das respostas em dado momento temos o que na metodologia qualitativa denomina-se "Ponto de saturação teórica" (PATTON, 2002).

\subsection{LOCAL E PARTICIPANTES DO ESTUDO}

A pesquisa foi realizada numa cidade do interior do Estado de Minas Gerais, situada na região Centro- Oeste. Esta possui 85396 habitantes, caracterizando-se por ter um perfil urbano.

A escolha dos participantes foi de conveniência (CRESWELL, 2014), sendo entendida como uma amostragem não probabilista, cujo objetivo é selecionar sujeitos 
próximos e acessíveis ao pesquisador. Os critérios de inclusão foram: sujeitos maiores de 18 anos, em tratamento, que relatam ao menos um episódio de recaída, sem comprometimento cognitivo grave que impossibilite a realização da entrevista e que se enquadre no diagnóstico de dependência em substâncias psicoativas pela CID-10. A amostra foi constituída de 17 pacientes na primeira entrevista e seis na segunda.

Os sujeitos da pesquisa foram usuários de um serviço especializado da cidade, $\mathrm{o}$ Centro de atenção psicossocial de álcool e drogas (CAPS ad II), que se localiza na periferia da cidade, em uma casa alugada, que possui uma ampla área externa onde são realizadas atividades, possui uma horta cultivada pelos pacientes, as verduras e legumes colhidos são vendidos para a comunidade e esse dinheiro revertido em material para o serviço.

O serviço conta com uma equipe de enfermagem, duas assistentes sociais, três psicólogos, uma terapeuta ocupacional, um psiquiatra que atende aos usuários em tratamento intensivo e em nível ambulatorial uma vez por semana, além de contar com estagiários das universidades da região, tanto de enfermagem quanto de psicologia e voluntários.

Entre as atividades realizadas o serviço tem: o cultivo da horta, exercícios físicos e de recreação, oficinas de artesanato, leituras e filmes, entre outras. Existem reuniões com os familiares e durante as datas comemorativas essas famílias são convidadas a participarem juntamente com os pacientes e funcionários.

O CAPS ad divide os pacientes em duas categorias: os que permanecem em CAPS dia, passando o período da manhã e tarde no serviço, nessa condição em média, permanecem de 15 a 20 pacientes, e os em regime ambulatorial, que são atendidos tanto pelo psiquiatra quanto pela psicóloga de referência.

Para a seleção dos entrevistados utilizou-se os informantes chaves (PATTON, 2002), que são indivíduos que conheciam os entrevistados, sua rotina e sua adesão ou não ao tratamento. Esses informantes foram trabalhadores de saúde assim como auxiliar administrativo que possuía o controle da marcação de consultas e retornos dos pacientes do local do estudo. 


\subsection{INSTRUMENTOS}

Como forma de coleta de informações utilizou-se de entrevistas semi- estruturadas (CRESWELL, 2009). Através de roteiro composto por duas modalidades de questões, perguntas fechadas, previamente uniformizadas para permitir a comparação de respostas entre os participantes da pesquisa e abertas que permitiram o aprofundamento dos temas. Durante o processo da entrevista foram inseridas outras questões conforme a necessidade de maior esclarecimento da pesquisadora. Nas questões abertas foram abordados os determinantes intrapessoais e interpessoais conforme descritos pelo referencial teórico da Prevenção de Recaída.

O roteiro foi construído com base em fundamentos teóricos da literatura específica. Para análise dos determinantes interpessoais (APENDICE B) foi focalizado o apoio social, entendido como um fenômeno de múltiplas dimensões associado à saúde do individuo, sendo um conjunto de recursos providos por outras pessoas (VAUX, 1988), incluindo os componentes destacados por Tardy (1985) e Vaux (1988). Para complementar os componentes destacados por esses autores, foram contempladas questões sobre o suporte social, embasadas no questionário de suporte social (SSQ) validado por Matsukura Marturano e Oishi (2002) que avalia a percepção do apoio social.

Nos determinantes intrapessoais (APENDICE C) seguiram-se aqueles contemplados por Marlatt e Witkiewitz (2009). Enfatizou-se a expectativa em relação ao uso da substância psicoativa e as situações ou comportamentos que levavam o indivíduo ao uso. A autoestima foi auscultada através de questões direcionadas à opinião que o usuário tinha sobre si mesmo e a que julgava que os outros atribuíam a ele. Também se pretendeu interrogar sobre a importância dessa opinião para o usuário no que se referia à decisão de mudança. $\mathrm{O}$ enfrentamento foi auscultado através de questões contempladas por Vives, Gárcia e Balsa (2001).

Para complementação do estudo um formulário sociodemográfico foi construído contemplando questões sociodemográficas e sobre o uso de outras SPA (APENDICE D). 


\subsection{PROCEDIMENTO}

O estudo incluiu um período de inserção no local da pesquisa com o objetivo de introduzir e familiarizar o pesquisador com o local, com os trabalhadores de saúde e com os entrevistados, no intuito de desenvolver uma maior interação e confiança (RIZZINI; CASTRO; SARTOR, 1999).

Nesse período a pesquisadora buscou observar o comportamento dos pesquisados, as relações interpessoais existentes entre eles e com os funcionários, além de dar início ao vínculo entre a pesquisadora e os entrevistados para a realização de grupos de educação em saúde. Solicitação feita pelo serviço como contrapartida para a realização da pesquisa.

Foi durante o primeiro grupo de educação em saúde que se realizou o convite para a participação da pesquisa, nesse primeiro dia o grupo contava com 30 participantes. Esses foram convidados e selecionados com a ajuda dos informantes chaves (psicólogos e secretária). Foram selecionados os que mostravam maior frequência ao serviço. Todos os 30 presentes concordaram em participar dos grupos semanais e das entrevistas a serem realizadas em dois momentos.

Havia a expectativa de participação de um número maior de entrevistados, tanto na primeira como na segunda entrevista, já que no primeiro encontro 30 usuários se apresentaram.

Ao longo das semanas, houveram perdas, devido às causas: abandono do tratamento, não comparecimento em mais de três entrevistas previamente marcadas com a pesquisadora (há de se destacar que o agendamento das entrevistas era realizado no mesmo dia em que estava marcada consulta com o psicólogo ou com o psiquiatra), mudança de cidade ou por algum motivo de reclusão seja por prisão ou ida para comunidade terapêutica.

$\mathrm{Na}$ primeira entrevista foram entrevistados 17 usuários. Esses pacientes faziam uso de crack como substância principal, mas a maioria também fazia o uso de outras SPA. Todos leram e assinaram o termo de consentimento livre e esclarecido- TCLE (APENDICE A). Nessa ocasião foi explicado aos participantes que após três meses seria realizada uma nova entrevista.

A primeira entrevista ocorreu entre Dezembro e Janeiro de 2013. Após três meses foi realizada uma nova de abordagem com esses mesmos participantes, conforme havia sido explicado durante o primeiro grupo de educação em saúde e reforçado na primeira entrevista. 
Essa segunda entrevista visou comparar a condição de uso ou abstinência da SPA do participante, para verificar se houve modificações significativas.

Na segunda entrevista, dos 17 usuários iniciais apenas seis participaram. Foram seguidos os mesmos critérios de agendamento da primeira entrevista, com várias tentativas adicionais para localizar os participantes. Os principais motivos para a não inclusão foram: não comparecimento nas datas marcadas das consultas médicas e psicológicas, internação em comunidade terapêutica, mudança de cidade e abandono do serviço de saúde (volta ao uso de substâncias psicoativas de maneira compulsiva).

Todas as entrevistas foram realizadas individualmente, no serviço de saúde em local reservado e gravadas, o tempo médio de duração foi de 20 minutos. Em caso de desconforto durante as questões apresentadas durante as entrevistas, os participante foram informados sobre o direito de recusar a responder ou interromper a entrevista a qualquer momento.

O projeto foi aprovado pelo Comitê de Ética em Pesquisa da Escola de enfermagem de Ribeirão Preto, Universidade de São Paulo (número CAAE 19403913.2.0000.5393). Foi garantido o anonimato das entrevistas a partir da identificação do material pelo código alfanumérico. Todos os dados pessoais foram arquivados de forma protegida e, quando expostos de alguma forma (trechos principalmente), o anonimato foi totalmente mantido.

\subsection{TRATAMENTO DOS DADOS: ANALISE QUALITATIVA}

De pose do material das entrevistas foi realizada a sua transcrição, leitura e aplicação das etapas previstas no processo de análise de conteúdo (BARDIN, 2009). Destacase que as categorias eram previamente determinadas com base no referencial teórico composto pelo modelo da Prevenção de Recaída e pelos outros conceitos já mencionados.

A análise de conteúdo consiste na explicitação e sistematização dos conteúdos que emergem dos relatos dos entrevistados com a finalidade de se buscar deduções lógicas sobre um dado fenômeno (BARDIN, 2009).

Cada entrevista, assim que concluída, recebeu um código alfanumérico que tinha a seguinte ordem: Iniciais do nome do entrevistado seguido de sua idade. Cada entrevista foi 
escutada três vezes pelas pesquisadoras e em seguida transcrita na integra, após o material foi submetido a uma comparação com o áudio original.

Com o material transcrito iniciou-se a análise de conteúdo proposta por Bardin (2009), considerando o roteiro de entrevista, que estava subdividido nas categorias definidas previamente conforme os sete determinantes (seis intrapessoais e um interpessoal) do referencial Teórico para a prevenção de recaída. A análise teve três etapas: pré-análise, exploração do material e tratamento dos resultados.

A pré-analise consistiu na leitura exaustiva do material coletado, o que levou a pesquisadora a se confrontar e analisar os relatos de maneira mais fluente, levando-o a levantar as primeiras hipóteses tanto dos relatos quanto das observações realizadas durante o estudo (BARDIN, 2009).

A exploração do material consistiu na edição das entrevistas, separando os textos em grandes temas, criando-se assim os grandes eixos temáticos (BARDIN, 2009). No caso desse estudo, com o material incluído nas categorias pré- definidas, portanto com a organização dos textos das entrevistas dentro das mesmas, a pesquisadora e orientadora realizaram uma releitura do texto de cada entrevista e do conjunto das mesmas e as redefiniram ajustando-as, processo esse que recebe o nome de codificação e que consiste no agrupamento dos trechos das entrevistas que teorizam uma ideia em comum (GIBBS, 2007). Através da codificação, trechos foram reagrupados de forma a fornecer novos significados. Esse processo resultou na geração de seis categorias: Motivo para o uso de substâncias psicoativas (A), Expectativa de uso (B), manejo da dependência (C), Estratégias de enfrentamento (D), Autopercepção e percepção de terceiros (E) e Fontes de apoio (F). 


\section{RESULTADOS}

Os resultados mostraram as características dos participantes do estudo, de forma a descrever a sua trajetória de vida, que inclui o uso de crack desde o início, suas expectativas em relação à substância, os motivos que alegaram para o uso e as dificuldades enfrentadas no controle do mesmo. Também revelaram as iniciativas de busca de tratamento, as opiniões a respeito disso e sobre a adesão. Mostram os meandros vivenciados no caminho em direção à abstinência, permeado pela recaída com a exposição dos determinantes que se identificaram como facilitadores da mesma. Também apareceram as estratégias de enfretamento e a percepção em relação a si e aos outros como possíveis motivações para o uso ou não e as percepções a respeito de quem consideram ou não seu apoio e a qualidade deste. O cenário da vida dos participantes, com os dados que o compõem é evidenciado e analisado em itens apresentados na sequência, após a exposição dos dados sociodemográficos.

\section{- DADOS SÓCIO-DEMOGRÁFICOS DOS PARTICIPANTES}

Antes da primeira entrevista foi aplicado um questionário sobre as características socioculturais dos indivíduos. O resultado se encontra no quadro abaixo.

\begin{tabular}{|c|c|c|c|c|c|c|c|c|}
\hline Código & Idade & Sexo & Escolaridade & Est. civil & Raça & $\begin{array}{l}\text { Fonte } \\
\text { renda }\end{array}$ & Religião & $\begin{array}{c}\mathbf{N}^{\mathbf{0}} \\
\text { recaídas }\end{array}$ \\
\hline WLM41 & 41 & $\mathrm{M}$ & $\begin{array}{c}\text { Fundamental } \\
\text { completo }\end{array}$ & Outros & Parda & Possui & Católica & $1-3$ \\
\hline FAG35 & 35 & $\mathrm{~F}$ & $\begin{array}{l}\text { Fundamental } \\
\text { incompleto }\end{array}$ & $\begin{array}{c}\text { Mora } \\
\text { companheiro }\end{array}$ & Branca & Desemp. & Protestante & $>5$ \\
\hline CAGL29 & 29 & $\mathrm{~F}$ & $\begin{array}{l}\text { Fundamental } \\
\text { completo }\end{array}$ & Solteira & Negra & Desemp. & Não tem & $1-3$ \\
\hline NCM17 & 17 & $\mathrm{~F}$ & $\begin{array}{l}\text { Ens. médio } \\
\text { incompleto }\end{array}$ & Solteira & Negra & Desemp. & Católica & $1-3$ \\
\hline MAJ27 & 27 & $\mathrm{M}$ & $\begin{array}{l}\text { Fundamental } \\
\text { completo }\end{array}$ & Solteiro & Negro & Desemp & Protestante & $1-3$ \\
\hline JMMS41 & 41 & $\mathrm{M}$ & $\begin{array}{c}\text { Médio } \\
\text { completo }\end{array}$ & $\begin{array}{c}\text { Mora } \\
\text { companheira }\end{array}$ & Branca & Desemp. & Protestante & $>5$ \\
\hline VJF44 & 44 & $\mathrm{M}$ & $\begin{array}{l}\text { Fundamental } \\
\text { incompleto }\end{array}$ & Outros & Parda & Desemp & Católica & $>5$ \\
\hline
\end{tabular}




\begin{tabular}{|l|c|c|c|c|c|c|c|c|}
\hline RCR54 & 54 & $\mathrm{M}$ & $\begin{array}{c}\text { Fundamental } \\
\text { completo }\end{array}$ & Outros & Parda & Possui & $\begin{array}{c}\text { Não } \\
\text { possui }\end{array}$ & $4-5$ \\
\hline VAG52 & 52 & $\mathrm{M}$ & $\begin{array}{c}\text { Fundamental } \\
\text { completo }\end{array}$ & Solteiro & Branca & Possui & Protestante & $>5$ \\
\hline MRAF33 & 33 & $\mathrm{M}$ & $\begin{array}{c}\text { Ensino } \\
\text { superior }\end{array}$ & Solteiro & Branca & Possui & Espírita & $>5$ \\
\hline HJM47 & 47 & $\mathrm{M}$ & $\begin{array}{c}\text { Ensino } \\
\text { Superior }\end{array}$ & Solteiro & Parda & Possui & Não tem & $1-3$ \\
\hline GDR49 & 49 & $\mathrm{M}$ & $\begin{array}{c}\text { Fundamental } \\
\text { completo }\end{array}$ & Outros & Parda & Possui & Protestante & $1-3$ \\
\hline EALS27 & 27 & $\mathrm{M}$ & $\begin{array}{c}\text { Médio } \\
\text { Incompleto }\end{array}$ & Solteiro & Parda & Possui & Católica & $>5$ \\
\hline RAS31 & 31 & $\mathrm{M}$ & $\begin{array}{c}\text { Médio } \\
\text { Incompleto }\end{array}$ & Solteiro & Branca & Desemp. & Não tem & $1-3$ \\
\hline MAL45 & 45 & $\mathrm{M}$ & $\begin{array}{c}\text { Médio } \\
\text { Incompleto }\end{array}$ & $\begin{array}{c}\text { Mora } \\
\text { companheiro }\end{array}$ & Parda & Possui & Protestante & $1-3$ \\
\hline WEN28 & 28 & $\mathrm{M}$ & $\begin{array}{c}\text { Fundamental } \\
\text { completo }\end{array}$ & Casado & Parda & Possui & Católica & $>5$ \\
\hline DAQ28 & 28 & $\mathrm{M}$ & $\begin{array}{c}\text { Fundamental } \\
\text { completo }\end{array}$ & Solteiro & Parda & Desemp. & Católica & $1-3$ \\
\hline
\end{tabular}

Quadros 1 - Dados sociodemográficos dos entrevistados

Conforme o expresso no quadro 1 , o estudo contou com participantes entre 17 e 54 anos, sendo a média de idade de 36,9 anos de idade. Em se tratando de gêneros 14 (82\%) participantes eram do sexo masculino e três (18\%) do feminino. O grau de escolaridade predominante foi o ensino fundamental completo com $47 \%$ (oito entrevistados), seguido pelo ensino médio incompleto com 23\% (quatro participantes), $9 \%$ (dois entrevistados) possuíam o ensino superior completo. O estado civil predominante foi o solteiro com nove entrevistados nessa situação (53\%). Em relação à raça, os 9 entrevistados se autorreferiram pardos (53\%), seguida de branca com cinco indivíduos $(29,4 \%)$ e apenas três $(17,6 \%)$ participantes se consideraram negros.

Nove (53\%) participantes referiram ter alguma fonte de renda, que variou entre aposentadoria, benefício ou emprego. Em se tratando de religião, houve o mesmo número de católicos e protestantes, seis, o que perfaz 35,3\%, um (5,9\%) indivíduo se manifestou espírita, os que não possuíam nenhuma religião somaram quatro $(23,5 \%)$.

Os participantes foram questionados sobre o número de recaídas que já tiveram com o uso de crack e nove (53\%) relataram de 1-3 episódios de recaída, seguida de sete $(41,1 \%)$ pacientes que relaram mais de cinco episódios de recaída, e apenas um $(5,9 \%)$ participante teve de 4-5 recaídas. Percebe-se que o grupo pesquisado teve diversas 
experiências de recaída ao longo do tempo de uso, corroborando assim a importância do estudo desse fenômeno.

\section{A.MOTIVOS DO USO DE SUBSTÂNCIAS PSICOATIVAS}

Percebeu-se durante os relatos dos participantes que o início do uso se deu através de outras substâncias psicoativas, principalmente da maconha durante a adolescência e só após alguns anos o crack foi introduzido:

"Com 15 anos eu já usava a maconha. O crack já tem 20 anos que eu uso. Agora eu não sei o que me fez fazer isso." WLM41

"Droga desde os 14 anos, com crack tem uns sete anos" JMMS41

Outro fator observado foi de que as substâncias psicoativas usadas anteriormente ou concomitante ao crack não foram percebidas como prejudiciais, ao contrário foram vistas como não interferindo nas funções psicossociais, ao contrário do próprio crack.

"Primeiro comecei com a maconha e depois com o crack. Aí que virou bagunça mesmo!" NCM17

"Enquanto eu usava só maconha eu trabalhava lá como técnico, mas depois que eu conheci o crack... acabou..." MRAF33

"Beber eu bebo, mas não prejudicava. Prejudicava assim: às vezes eu bebia demais, desmaiava e tinha que ir para o hospital... pronto socorro. Mas não prejudicava em nada com a mulher, não batia, nem nada. Eu era melhor para ela quando tava bebendo do que quando sóbrio." VJF44

Em relação à obtenção do crack/ cocaína está se dava através da compra, com recursos do próprio usuário. 
"O dinheiro do salário ficava tudo lá. O último salário da empresa foi de $\mathrm{R} \$ 840,00$ e eu fui para a boca (local de venda da SPA).” WLM41

"Eu trabalhava em um motel e todo fim de semana eu tinha um vale (dinheiro), sabe? E o vale nem chegava a entrar em casa. A mulher nem sabia do vale. Ai que eu vi que tava prejudicando demais mesmo. "RCR54

"Não roubava, comprava através do trabalho, eu nunca roubei nada" RAS31

Outro meio de obtenção foi mediante a venda de objetos pessoais e penhora de objetos de menor ou maior valor, chegando até mesmo à venda de alimentos existentes na residência.

"Vendia tudo, vendi televisão, meu som, moto..." JMMS41

“(Eu) tenho que pegar algo meu e vender para usar. Agora eu não tenho mais dinheiro para usar. A minha última venda foi um quilo de carne que ele (marido) comprou." FAG35

"Porque todas as vezes que eu recaio deu nas mesmas consequências... é um celular que vai embora, é o meu carro que eu penhoro na boca de fumo, já fiz isso muito, pegar meu carro e dar para o traficante por causa de pedra e depois eu pego meu carro, complicado" WEN28

Das mulheres entrevistadas, duas relataram obter a substância psicoativa através da prostituição.

“Eu me prostituia mesmo.” CAGL29

Os participantes foram questionados nas duas entrevistas sobre o que os levava a fazer o uso do crack, ao categorizar as respostas incluíram-se as situações vivenciadas, estados emocionais, momentos de lazer, possessão espiritual e uso de outra substância psicoativa, sendo que em todas se identificou subitens como se pode observar no quadro abaixo, em que a coluna "número" significa quantos participantes citaram o subitem da categoria. 


\begin{tabular}{|c|c|c|}
\hline Motivos do uso & Participante & Número \\
\hline $\begin{array}{c}\text { Situações } \\
\text { vivenciadas }\end{array}$ & $\begin{array}{l}\text { "O ambiente que eu vivi mexia e isso favoreceu eu } \\
\text { mexer também. O povo oferecia e eu dizia que } \\
\text { não mexia com isso... bebia só de vez em quando, } \\
\text { mas acabou que um dia eu fumei maconha, o povo } \\
\text { falava que eu dava uma de gostoso. Só de você ver } \\
\text { as pessoas usando você já está sendo } \\
\text { influenciado." RAS31 }\end{array}$ & 1 partic. \\
\hline Desocupação & $\begin{array}{l}\text { "Eu usava porque não tinha nada para } \\
\text { fazer."VAG52 }\end{array}$ & 2 partic. \\
\hline Fracasso & $\begin{array}{l}\text { "O pai dos meus filhos usava, ai eu fui tentar } \\
\text { ajudar ele e eu não consegui, eu me senti uma } \\
\text { fracassada. Daí comecei a usar também." } \\
\text { CAGL29 }\end{array}$ & 2 partic. \\
\hline Relações conjugais & $\begin{array}{l}\text { "Eu tô aqui numa boa, nem to lembrando de } \\
\text { maconha, ai quando eu tô chegando em casa já me } \\
\text { dá aquela fissura." RCR54 }\end{array}$ & 2 partic. \\
\hline $\begin{array}{l}\text { Estados } \\
\text { emocionais* }\end{array}$ & $\begin{array}{l}\text { “... quando eu ficava com raiva de alguma coisa } \\
\text { também ai eu ia beber e quando eu bebia dava } \\
\text { vontade de usar também" RAS } 31 \\
\text { "Usar as drogas e colocar tudo a perder, isso me } \\
\text { estressa, isso me joga fora" NCM17 }\end{array}$ & 6 partic. \\
\hline Ansiedade & $\begin{array}{l}\text { "Não sei, uma ansiedade, uma fissura! Uma coisa } \\
\text { assim inexplicável!" CAGL29 }\end{array}$ & 4 partic. \\
\hline
\end{tabular}




\begin{tabular}{|c|c|c|}
\hline Solidão & $\begin{array}{l}\text { "Eu dependia dela (esposa) para viver, eu me senti } \\
\text { sozinho, senti a falta, me senti traído." GDR49 }\end{array}$ & 1 partic. \\
\hline Vazio & $\begin{array}{l}\text { "Quando você pensa que não está valendo nada } \\
\text { mais." VJF44 } \\
\text { "Quando eu fico triste, quando eu fico magoada } \\
\text { com alguma coisa, ai volta tudo (as perdas) de } \\
\text { novo na minha cabeça e eu tenho que usar" } \\
\text { FAG35 }\end{array}$ & 4 partic. \\
\hline Depressão & $\begin{array}{l}\text { "Porque o efeito dela é muito rápido e depois dá } \\
\text { um efeito de depressão alto." RAS31 }\end{array}$ & 1 partic. \\
\hline $\begin{array}{l}\text { Momentos de } \\
\text { lazer }\end{array}$ & $\begin{array}{l}\text { "A droga em si não era o problema, eu usava em } \\
\text { pequenas doses, mas quando eu comecei a } \\
\text { envolver a droga com sexo, festa, com farra e } \\
\text { adrenalina ai desencadeou o problema." HJM47 }\end{array}$ & 2 partic. \\
\hline Companhias & $\begin{array}{l}\text { "Antigamente eu andava só com gente maluca." } \\
\text { WLM } 41\end{array}$ & 2 partic. \\
\hline $\begin{array}{l}\text { Uso de outras } \\
\text { substâncias }\end{array}$ & $\begin{array}{l}\text { "Para mim a bebida e a droga são uma } \\
\text { combinação, quando eu bebia dava vontade de } \\
\text { usar a droga e quando eu usava a droga dava } \\
\text { vontade de beber. Ai eu bebia demais e usava } \\
\text { droga." RAS31 } \\
\text { "Já bebia o que já é um gatilho aberto, né? Vou te } \\
\text { falar quem faz uso de álcool tem oitenta por cento } \\
\text { de fazer o uso de cocaína, eu te garanto! Quase } \\
\text { todos que eu conversei faziam o uso do álcool." } \\
\text { MAL45 }\end{array}$ & 4 partic. \\
\hline
\end{tabular}




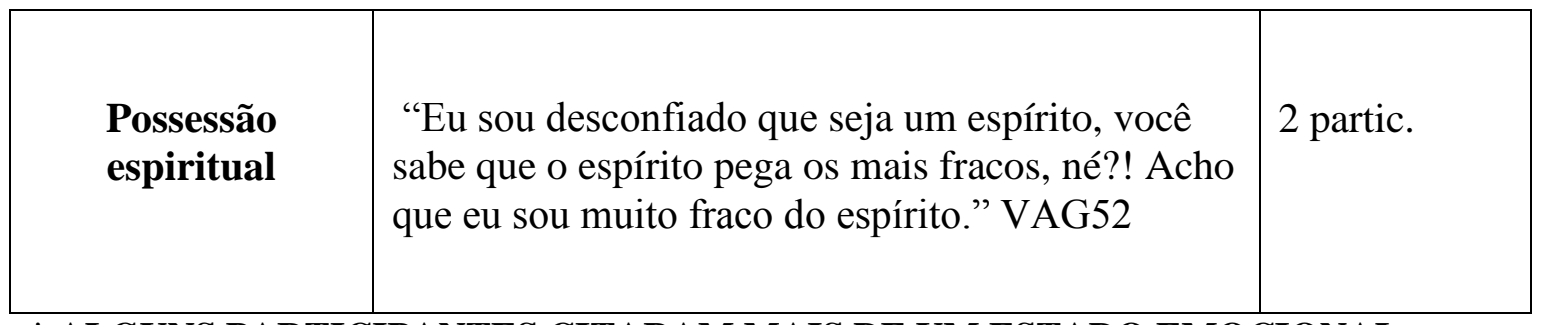

\section{* ALGUNS PARTICIPANTES CITARAM MAIS DE UM ESTADO EMOCIONAL}

QUADRO 2: Motivos do uso de Substâncias psicoativas e do crack

Entre os motivos para o uso, predominaram os estados emocionais com 11 participantes, sendo que alguns participantes citaram mais de um estado emocional como motivador para o uso, perfazendo 16 respostas. Em seguida tiveram-se as situações vivenciadas, relatada por sete participantes, os momentos de lazer e o uso de outras SPA apareceram com a mesma relevância (quatro participantes respectivamente cada uma). E por último a possessão espiritual, com dois participantes.

Sobre os onze que citaram os estados emocionais, lembrando que alguns participantes citaram mais de um estado emocional perfazendo 16 respostas ao todo, seis $(37,5 \%)$ citaram a raiva como principal fator, seguido pela ansiedade e sensação de vazio citadas por quatro participantes $(25 \%)$ cada item, um falou sobre depressão $(6,25 \%)$ e um sobre a solidão $(6,25 \%)$.

$\mathrm{Na}$ subcategoria situações vivenciadas, sete participantes a relataram, sendo que dois perceberam os fracassos vivenciados como desencadeadores do uso de SPA, dois expuseram suas relações conjugais como complicadores para a abstinência ou redução do uso, dois mencionaram a ociosidade (não ter o que fazer) como desencadeante para o uso e um citou a influência dos amigos.

Outro motivador para o uso de SPA relatado pelos participantes foi relacionado aos momentos de prazer, sendo que quatro participantes falaram sobre isso, dois citaram as companhias como motivadores e dois relataram os momentos de extroversão como prejudiciais ao controle. Assim como quatro participantes relataram que o álcool desencadeava a vontade de usar crack.

A possessão espiritual também apareceu como motivador sendo que dois participantes relataram sofrerem algum tipo de interferência de "espíritos" para o uso de SPA. 


\section{B.EXPECTATIVAS EM RELAÇÃO À SUBSTÂNCIA}

O quadro 3 demonstra as expectativas que os participantes alegaram para fazerem uso de crack, sendo que esse item foi abordado apenas na primeira entrevista.

\begin{tabular}{|c|c|}
\hline \multicolumn{2}{|c|}{ Expectativas em relação à substância psicoativa } \\
\hline Morrer & $\begin{array}{l}\text { "Uai, eu perdi meu noivo e eu queria morrer. Eu entrei no crack } \\
\text { porque eu queria morrer" FAG35 } \\
\text { "Morrer... mais isso era sem saber!" GDR49 } \\
\text { "Já tentei usar também para tentar morrer, assim para ver se dava } \\
\text { uma overdose" RAS31 }\end{array}$ \\
\hline Farra/ prazer & $\begin{array}{l}\text { "Uma farra, lá na casa, três homens e três mulheres... uma farra. } \\
\text { Pensei que no outro dia saia." GDR49 } \\
\text { "Prazer. Como disse Dalai Lama que tem gente que fala... se } \\
\text { confunde dizendo que usar droga é incoerente, mentira! Usar droga } \\
\text { é coerente com seus objetivos, se seu objetivo é ter prazeres fugazes } \\
\text { e inconsequentes a droga é lógica... se você almeja melhorar de } \\
\text { vida, ter uma vida social e construir uma família sólida, não! } \\
\text { Depende de seus objetivos, meus objetivos na época era ter prazeres } \\
\text { fugazes..." HJM47 }\end{array}$ \\
\hline Curiosidade & $\begin{array}{l}\text { "Curiosidade para saber como que é e tal, mas na verdade foi uma } \\
\text { falsa fuga, para mim é uma fuga hoje em dia eu vejo." MAL45 } \\
\text { "Usava mesmo por curiosidade. E um pouco porque eu larguei da } \\
\text { minha namorada, ai eu fui me afundando no crack e na cocaína." } \\
\text { DAQ28 }\end{array}$ \\
\hline Erro de caráter & "A gente usa a droga por erro de caráter." WEN28 \\
\hline Sentir o efeito & $\begin{array}{l}\text { "Eu não esperava nada. Esperava aquele momento. Eu sabia, eu } \\
\text { sabia que tava fazendo mal" RCR54 } \\
\text { "Geralmente são situações que eu quero parar de pensar. Eu quero } \\
\text { fazer minha cabeça parar de funcionar, porque eu sou imperativo." } \\
\text { MRAF33 }\end{array}$ \\
\hline
\end{tabular}

QUADRO 3: Expectativas em relação a substância psicoativa 
Nove participantes responderam a esse questionamento (sendo que um participante citou duas categorias). Foram cinco as expectativas em que as expressões dos participantes se encaixaram: querer morrer com três participantes (30\%), busca de interação com outros, com dois participantes a relatando (20\%), curiosidade com $20 \%$ também, sentir o efeito com o mesmo percentual de $20 \%$ e o erro de caráter com um participante o citando (10\%)

Sendo que o início do uso pareceu estar vinculado a atingir um objetivo, podendo ser uma maneira de lidar com acontecimentos tidos como insuportáveis (perdas reais ou subjetivas), realizar uma atividade que promova a interação com outros e com o sexo oposto, laços e prazeres transitórios ou apenas querer se desligar. Apenas um mencionou que o uso ocorria devido à "deficiência" individual (erro de caráter). O participante em questão relatou que aprendeu na clínica de recuperação sobre isso, demonstrando assim o pensamento determinista que é pregado em alguns locais, outros entrevistados também falaram sobre o fato do uso da droga e a dependência serem devido a um erro do indivíduo.

\section{MANEJO DA DEPENDÊNCIA (LIDAR COM A DEPENDÊNCIA)}

O manejo da dependência foi dividido entre o padrão de uso de substâncias psicoativas antes do inicio do tratamento no CAPS ad e a evolução desse uso durante o tratamento, incluindo a autoeficácia do participante perante o uso, a abstinência, as estratégias usadas para evitar a recaída e as possibilidades de manutenção do uso durante o tratamento. Dada a riqueza de informações trazidas pelas falas dos participantes, as mesmas foram agrupadas em subitens.

Em relação ao consumo de drogas antes e durante o tratamento, os relatos dos participantes da primeira entrevista, mostraram que o uso de crack era intenso e diário antes da entrada para o CAPS ad. O uso fora de controle ou em binge, (padrão de uso pesado de álcool ou outra substância, em uma única ocasião. CAREY, 2001), são os principais motivos que levaram os participantes a procurar tratamento. 
"Não era todo dia, eu tinha essa vantagem! Era mais no fim de semana. Mas ultimamente, antes de entrar para cá, tava demais. Eu tava gastando demais..." RCR54

"Usava (crack) duas vezes no mês... mais eu usava 70 pedras de crack (em cada uso)" MRAF33

"Uai, antes de entrar para cá era dia e noite. Ai depois que eu entrei para cá mudou minha mente, não tô usando mais... muito difícil." VAG52

Nas frases seguintes, percebem-se indícios de que houve uma mudança na frequência e/ou quantidade de uso após o inicio do tratamento e após três meses da primeira entrevista, os participantes que continuaram a frequentar o serviço (seis entrevistados) informaram diminuição do uso e até mesmo a abstinência.

\footnotetext{
"Tem uns 15 dias (que está sem fazer o uso), essa semana eu estou usando os remédios." VJF44

"Só final de semana" NCM17

“Hoje já tem... têm uns nove meses que eu não uso nada." HJM47
}

A tabela a seguir resume o padrão do uso de crack e cocaína dos participantes antes do início do tratamento no CAPS ad.

Tabela 1: Uso de crack e cocaína antes do início do tratamento_Minas Gerais, 2013

\begin{tabular}{lcc}
\hline Frequência & Crack & Cocaína \\
\hline Uso diário & $12(70,6 \%)$ & $2(11,7 \%)$ \\
Uso semanal & $4(23,5 \%)$ & $2(11,7 \%)$ \\
Uso mensal & $1(5,9 \%)$ & $1(5,9 \%)$ \\
Não usava ha mais de três semanas & - & $2(11,7 \%)$ \\
Não faz uso & - & $10(59 \%)$ \\
\hline
\end{tabular}

A tabela corrobora as falas dos participantes, ao mostrar que 70,6\% dos entrevistados faziam o uso diário de crack. O uso de cocaína não era frequente e determinante nos pacientes em tratamento para o uso de crack, tem-se que 59\% não fazia o uso.

Já o uso de outras substâncias psicoativas também estava presente como demonstrado pelas falas anteriores e evidenciado no quadro a seguir (Tabela 2). 
Tabela 2: Uso de outras substâncias psicoativas antes do inicio do tratamento_ Minas Gerais, 2013

\begin{tabular}{llcc}
\hline Frequência & Álcool & Tabaco & Maconha \\
\hline Não usa & $5(29,4 \%)$ & $3(17,7 \%)$ & $7(41,2 \%)$ \\
Uso diário & $7(41,2 \%)$ & $12(70,6 \%)$ & $7(41,2 \%)$ \\
Uso semanal & $3(17,7 \%)$ & - & - \\
Esporádico & $2(11,7 \%)$ & $2(11,7 \%)$ & $3(17,7 \%)$ \\
\hline
\end{tabular}

A substância mais utilizada pelos participantes na primeira entrevista foi o tabaco com uso diário de 70,6\%, esse dado é corroborado pela fala de RCR54:

"Fumo, não consigo largar não. Tento, acho que é a droga mais difícil de largar." RCR54

"O que eu tenho vontade é de cigarro, cigarro normal" VJF44

A Maconha e o álcool foram utilizados com a mesma frequência diária por 41,2\% dos entrevistados, sendo que a maconha foi percebida como substância que "acalma", que "fazem passar" a fissura e aumenta o apetite.

"A maconha faz passar a vontade de fumar (crack) demais, ajuda muito!" NCM16

“Às vezes uma maconha para dar fome, mais bem pouquinho" VJF44

O álcool foi mencionado como gatilho ou porta de entrada para o uso do crack

“... quando eu ficava com raiva de alguma coisa também, ai eu ia beber e quando eu bebia dava vontade de usar (crack) também” RAS31

“Me dá vontade(crack) só se eu beber.” EALS27

“Já que o meu problema com o crack é o álcool.”HJM47 
"Para mim a bebida e a droga são uma combinação, quando eu bebia dava vontade de usar a droga e quando eu usava a droga dava vontade de beber. Ai eu bebia demais e usava droga demais e meu dinheiro estava indo tudo nisso." RAS31

Percebeu-se também na segunda entrevista, que houve uma diminuição na frequência do uso de crack e cocaína, como já mencionado, mas em se tratando das outras substâncias psicoativas houve a manutenção do uso devido aos benefícios "terapêuticos" relatados.

“Cigarro normal ai passa a vontade (do uso de crack)"VJF44

"Tipo semana retrasada eu perdi meus remédios, ai eu ficava sem dormir, ai eu usava o álcool e dormia."VJF44

“Eu quero ter uma vida normal, sai para dançar e beber.” FAG35

\section{- AUTOEFICÁCIA E ABSTINÊNCIA}

Quanto à autoeficácia( quadro 4) essa foi subdividida em dificuldades em se manter o controle, expectativa de controle, medo da volta e recaída. Nessa perspectiva de continuum a abstinência (quadro 5) pode ser percebida como o ponto máximo do comportamento autoeficaz.

\begin{tabular}{|c|l|l|}
\hline $\begin{array}{c}\text { Controle } \\
\text { (autoeficácia) }\end{array}$ & Participante & Número \\
\hline Dificuldades & $\begin{array}{l}\text { "Não sei te dizer, é uma vontade inexplicável... } \\
\text { inexplicável... é uma vontade... parece que está no } \\
\text { sangue. Uma vontade terrível de usar" FAG35 }\end{array}$ & 3 partic. \\
\hline
\end{tabular}




\begin{tabular}{|c|c|c|}
\hline Apoio social & $\begin{array}{l}\text { "O que dificulta controlar é..(silêncio prolongado) } \\
\text { o que dificulta o não uso é não ter o apoio na } \\
\text { verdade, um apoio" RAS31 }\end{array}$ & 1 partic. \\
\hline $\begin{array}{l}\text { Falta de } \\
\text { reconhecimento do } \\
\text { problema }\end{array}$ & $\begin{array}{l}\text { "Enquanto você não reconhecer que você é um } \\
\text { doente da droga, que aquilo é uma doença, você } \\
\text { tem justificativa para usar ela, enquanto eu não } \\
\text { percebi que eu era um doente um dependente da } \\
\text { droga, eu não consegui parar." MAL45 }\end{array}$ & 1 partic. \\
\hline $\begin{array}{l}\text { Controle de } \\
\text { sintoma } \\
\text { psiquiátrico }\end{array}$ & $\begin{array}{l}\text { "Eu uso quando começo a falar mal de Deus, } \\
\text { começo a blasfemar ai eu uso ou quando saio de } \\
\text { casa e um colega oferece ai eu fico calado, mas ai } \\
\text { começo a falar mal de Deus, ai uso, vou fundo e se } \\
\text { eu não usar eu continuo falando mal Dele." } \\
\text { VAG52 }\end{array}$ & 1 partic. \\
\hline $\begin{array}{l}\text { Expectativas de } \\
\text { controle }\end{array}$ & $\begin{array}{l}\text { "Já tive umas chances e eu não usei." VJF44 } \\
\text { "O mesmo motivo que te leva a largar a droga é o } \\
\text { mesmo motivo que te leva a usar a droga! Se você } \\
\text { tem um objetivo e esse é coerente com o uso da } \\
\text { droga você vai voltar a usar a droga. Se o seu } \\
\text { objetivo diverge com o da droga, você vai se } \\
\text { afastar. Na verdade você tem que tratar a causa, } \\
\text { que é a falta de objetivos... Força eu sempre tive, } \\
\text { só não tinha interesse" HJM47 }\end{array}$ & 5 partic. \\
\hline Medo da volta & $\begin{array}{l}\text { "Eu tenho muito medo, mais eu vou ser forte, } \\
\text { quero ser forte.”FAG35 } \\
\text { "Não, eu não me sinto totalmente fortalecida não. } \\
\text { Porque pode vim à recaída." CAGL29 } \\
\text { "Me sinto fortalecido, com forças. Minha maior } \\
\text { dúvida é se eu ver um "crakeiro", quero ver minha } \\
\text { reação." WLM41 }\end{array}$ & 5 partic. \\
\hline Recaída & $\begin{array}{l}\text { "Uma, duas, três... já é a terceira vez que eu paro e } \\
\text { volto a usar." RAS31 } \\
\text { "Ainda tenho uma recaídas, mas em comparação... } \\
\text { Eu ficava era } 15 \text { dias bebendo direto, agora fico } \\
\text { até mês..."VJF44 } \\
\text { "Tentava emprego e nada ai eu voltei a usar. Ai,eu } \\
\text { fui para o fundo do poço, comecei a ouvir vozes, }\end{array}$ & 9 partic. \\
\hline
\end{tabular}




\begin{tabular}{|l|l|}
\hline & $\begin{array}{l}\text { ver espíritos e gente morta. Tava pensando muito } \\
\text { em suicídio, gente doente... ai eu vim para o } \\
\text { CAPS, ai eu tinha recaída... usava no fim de } \\
\text { semana e no meio da semana ficava sem usar." } \\
\text { JMMS41 } \\
\text { "Eu segurei oito anos, quando fiquei em uma } \\
\text { fazenda católica, aí eu recaí e fui para uma } \\
\text { fazenda evangélica e fiquei lá uns seis meses. } \\
\text { Agora eu dei uma recaída de março para cá eu tive } \\
\text { uma recaída, voltei dobrado." RCR54 }\end{array}$ \\
\hline
\end{tabular}

QUADRO 4: Autoeficácia

Sobre a autoeficácia o item mais destacado pelos participantes foi a recaída, citada por nove participantes, sendo que dois relataram passagens por comunidades e hospitais psiquiátricos como períodos em que mantiveram a abstinência, mas após esses períodos de reclusão ocorreu a recaída. Um participante relatou que a recaída ocorre por algo que vai além do desejo da pessoa, chegando até mesmo a ter uma interferência mística e ligada aos acontecimentos cotidianos.

O segundo item mais relatado pelos entrevistados foram as dificuldades em se manter o controle, com seis participantes, sendo que a fissura é citada por três participantes como maior empecilho para o controle, sendo que dois participantes fizeram uma ligação da fissura com algo orgânico, que estaria no sangue. Um participante pontuou sobre a falta de apoio como fator que dificulta o controle, outro citou a falta de reconhecimento do problema como a principal dificuldade e por último um participante com esquizofrenia falou sobre a diminuição das "vozes” de cunho místico religioso com o uso de SPA.

Em terceiro temos dois itens com o mesmo grau de relevância para os entrevistados, que foram à expectativa de controle e medo da volta, com cinco cada. Sobre a expectativa de controle um participante ligou o fato do controle do uso com a mudança de perspectiva e metas de vida, outro relatou não sentir mais vontade, conseguindo levar uma vida longe das drogas e um terceiro falou do benefício de estar frequentando uma religião e de ter planos futuros. O VJF44 chegou a relatar as recaídas, mas reconheceu que estava conseguindo reduzir o uso. 
"Tem umas recaídas, mas em comparação... Eu ficava era 15 dias direto." VJF44

Dos cinco participantes que falaram sobre o medo de uma recaída, quatro se disseram fortalecidos e sem medo de recair, sendo que um até relatou querer ver um usuário para "testar" sua determinação. Apenas uma participante referiu não se sentir fortalecida e temer a recaída, essa participante após três meses da primeira entrevista não participou da segunda devido a uma recaída.

Em relação à abstinência (quadro 5), agruparam-se as percepções dos participantes e realizou-se uma comparação das respostas da primeira entrevista e da segunda, com os seis participantes que continuaram o tratamento.

\begin{tabular}{|c|c|c|}
\hline Participante & $\mathbf{1}^{\mathrm{a}}$ entrevista & $2^{a}$ entrevista \\
\hline FAG35 & $\begin{array}{l}\text { Não citou o tema na } \\
\text { entrevista }\end{array}$ & "Tem um mês que eu não uso" \\
\hline RAS31 & "Já tem uns 5 meses." & $\begin{array}{l}\text { "Deve ter uns } 10 \text { meses que eu não uso } \\
\text { nada" }\end{array}$ \\
\hline VJF44 & $\begin{array}{l}\text { Não citou o tema na } \\
\text { entrevista }\end{array}$ & $\begin{array}{l}\text { "Tem uns } 15 \text { dias, essa semana eu } \\
\text { estou usando os remédios." }\end{array}$ \\
\hline VAG52 & $\begin{array}{l}\text { "Nos primeiros } 40 \text { dias eu } \\
\text { fiquei sem por nada na boca. } \\
\text { É só pedra que eu fumo, a } \\
\text { maconha eu já larguei." }\end{array}$ & Não citou o tema na entrevista \\
\hline HJM47 & $\begin{array}{l}\text { “... Eu estou desintoxicado } \\
\text { há cinco meses, cinco meses } \\
\text { que eu não uso, né?!” }\end{array}$ & $\begin{array}{l}\text { "Hoje já tem... têm uns nove meses } \\
\text { que eu não uso nada." }\end{array}$ \\
\hline CAGL29 & “4 meses que não uso.” & Abandonou o tratamento \\
\hline JMMS41 & $\begin{array}{l}\text { "De um mês para cá eu } \\
\text { parei. E quando eu usava } \\
\text { droga, mesmo quando não } \\
\text { usava, eu não tinha sossego } \\
\text { para dormir não, uns } \\
\text { espíritos me segurando, me } \\
\text { agarrando, parecia espírito } \\
\text { ruim mesmo. Agora graças a } \\
\text { Deus eu fui para a igreja e }\end{array}$ & Foi para comunidade terapêutica \\
\hline
\end{tabular}




\begin{tabular}{|l|l|l|}
\hline & parou." & \\
\hline RCR54 & $\begin{array}{l}\text { "O crack eu já parei... Tive } \\
\text { ontem na boca do fumo, } \\
\text { comprei 10 reais em fumo e } \\
\text { tinha 600 reais no bolso e } \\
\text { não me lembrei de comprar } \\
\text { nem uma pedra, entendeu...." }\end{array}$ & Abandonou o tratamento \\
\hline WEN28 & $\begin{array}{l}\text { "Vai fazer um mês( sem } \\
\text { fazer o uso)... já fiquei sete } \\
\text { meses, ai você olha para trás } \\
\text { e pensa "começar tudo de } \\
\text { novo"." }\end{array}$ & Abandonou o tratamento \\
\hline
\end{tabular}

QUADRO 5- Abstinência

Na primeira entrevista seis participantes relataram seu tempo de abstinência do crack, que variou de um a cinco meses. No segundo encontro quatro participantes responderam, sendo que o tempo de abstinência variou de quinze dias a dez meses. Os dois que mantinham a abstinência no primeiro encontro por mais de quatro meses o mantiveram no segundo.

Os profissionais do serviço relataram que dos 17 entrevistados iniciais, um certamente voltou ao padrão de consumo anterior ao tratamento, três foram para comunidades terapêuticas, um mudou de cidade, não sendo possível buscar notícias sobre o atual estado e outro se encontra recluso em uma penitenciária, porém estava em terapia medicamentosa. Os demais não compareceram aos dias marcados para a entrevista e consultas medicas/psicoterapias, não havendo mais informações.

\section{ESTRATÉGIAS DE ENFRENTAMENTO}

Estratégia de enfrentamento ocorre quando o indivíduo antecipa os efeitos que se espera obter em consequência do uso da substância. Essas expectativas podem ser de caráter 
físico, psicológicos ou comportamentais e nem sempre condizem com os efeitos reais do uso da droga (MARLLAT; WITKIEWITZ, 2009).

A categoria estratégias de enfrentamento teve nove subcategorias: frequentar o grupo, buscar ocupação, usar outra substância psicoativa, autossugestão, apego a crença religiosa, uso de medicação, motivação, desviar dos pontos de venda e ficar em casa.

\begin{tabular}{|c|c|c|}
\hline $\begin{array}{l}\text { Estratégias de } \\
\text { enfrentamento }\end{array}$ & Participante & Número \\
\hline $\begin{array}{l}\text { Frequentar o } \\
\text { grupo } \\
\text { CAPS }\end{array}$ & $\begin{array}{l}\text { "Aqui é bom, aqui o tratamento é bom... fiquei } \\
\text { rodando por ai uns seis meses ai vim para cá” } \\
\text { VAG52 } \\
\text { "O tratamento está sendo muito bem conduzido, } \\
\text { mas ele foi pesado, é um processo bem doloroso } \\
\text { de aprendizagem. O tratamento é pesado, é tão } \\
\text { pesado quanto à pessoa é capaz de fazê-lo } \\
\text { pesado.” HJM47 }\end{array}$ & 2 partic. \\
\hline NA & $\begin{array}{l}\text { "Frequentar os alcoólatras anônimos e os } \\
\text { narcóticos anônimos." DAQ28 }\end{array}$ & 1 partic. \\
\hline Buscar ocupação & $\begin{array}{l}\text { "Eu tenho que ficar o tempo todo ocupando } \\
\text { minha cabeça com alguma coisa." RAS31 } \\
\text { "Eu venho para cá, fico aqui... Quando tô em casa } \\
\text { procuro arrumar alguma coisa, distrair um pouco, } \\
\text { sempre ocupando a mente" CAGL29 } \\
\text { "Eu saio, vou catar latinha... ai eu esqueço." } \\
\text { VJF44 }\end{array}$ & 5 partic. \\
\hline Uso de outra SPA & $\begin{array}{l}\text { "Quando dá vontade de fumar crack eu fumo um } \\
\text { baseado, ai eu paro e fico calmo, fico tranquilo." } \\
\text { RCR54 } \\
\text { "Às vezes uma maconha para dar fome, mas bem } \\
\text { pouquinho" VJF44 }\end{array}$ & 3 partic. \\
\hline $\begin{array}{l}\text { Apego à crença } \\
\text { religiosa }\end{array}$ & $\begin{array}{l}\text { "Eu to tentando arrumar emprego, continuar indo } \\
\text { na igreja, to indo lá frequentemente, tem um cara } \\
\text { lá que tá me ajudando. Estou lendo a bíblia." }\end{array}$ & 3 partic. \\
\hline
\end{tabular}




\begin{tabular}{|c|c|c|}
\hline & $\begin{array}{l}\text { JMMS41 } \\
\text { "Vou à igreja, oro, procuro o senhor." GDR49 }\end{array}$ & \\
\hline Uso de medicação & $\begin{array}{l}\text { "Eu tomo ele (remédio) e nem dá tempo de sair? } \\
\text { Não dá vontade não ( quando eu passo perto do } \\
\text { bar), com esses remédios só de sentir o cheiro da } \\
\text { pinga dá vontade de vomitar" VJF44 } \\
\text { "Estou fazendo o uso do remédio. Quando ele } \\
\text { começa a acabar eu fico nervoso." WLM41 }\end{array}$ & 3 partic. \\
\hline $\begin{array}{c}\text { Motivação } \\
\text { (querer parar) }\end{array}$ & $\begin{array}{l}\text { "Agora sim, antes não. Antes eu não queria não, } \\
\text { por isso não tinha parado. O pessoal pegou no } \\
\text { meu pé, forçou a barra. A primeira vez que parei } \\
\text { eu não queria parar não, quando juntou a "metade } \\
\text { do mundo", o mundo inteiro se juntou e se } \\
\text { inspirou para eu internar, eu não queria parar, isso } \\
\text { não faz ninguém parar e várias pessoas que eu } \\
\text { conheço que não tinham motivação todos } \\
\text { voltaram..." HJM47 } \\
\text { "Eu coloquei na cabeça e parei" EALS27 }\end{array}$ & 4 partic. \\
\hline $\begin{array}{c}\text { Desviar dos } \\
\text { pontos de venda e } \\
\text { usuários }\end{array}$ & $\begin{array}{l}\text { "Antes eu vinha aqui na quinta e passava lá no } \\
\text { ponto para buscar, mas já tem um mês que eu } \\
\text { estou dando a volta, mudando de lado para não ter } \\
\text { contato, para não ir lá.” FAG35 } \\
\text { "Eu afastei deles também, dos viajantes (colegas } \\
\text { de profissão).” VJF44 }\end{array}$ & 2 partic. \\
\hline Ficar em casa & $\begin{array}{l}\text { "Fico em casa e não estou saindo para nada, para } \\
\text { nada." RAS31 }\end{array}$ & 3 partic. \\
\hline
\end{tabular}

QUADRO 6 - Estratégias de enfrentamento

A estratégia mais utilizada pelos participantes foi buscar uma ocupação, citada por cinco participantes, seja com trabalhos manuais e artesanais ou trabalhos informais que geram fonte de renda, seguidas por ter motivação (querer parar), com quatro participantes, um até mesmo citou que a motivação para a mudança de comportamento deveria partir de si mesmo, independentemente da opinião ou desejo de outras pessoas. 
Com o mesmo nível de relevância, com três participantes citando cada item, teve-se o frequentar o grupo, o uso de outra SPA, apego a crença religiosa, uso da medicação e o ficar em casa.

Sobre o frequentar o grupo os participantes citaram o CAPS e os narcóticos anônimos. O uso de outra substância psicoativa apareceu na fala de dois entrevistados que relataram fazer uso de maconha para "retirar" a fissura/ vontade de usar o crack. E um participante relatando o uso de maconha não como forma de superar a fissura, mas para o aumento do apetite.

O apego a alguma crença religiosa também apareceu com a mesma relevância dos itens acima, com três citações, como forma de alívio e esperança na recuperação, em algumas organizações religiosas tem-se o apoio por parte dos indivíduos que frequentam o mesmo local, criando-se uma rede de ajuda e apoio.

O uso dos medicamentos também foi citado por três participantes como peça importante para o tratamento, já que auxilia no controle da fissura e ajuda a amenizar a ansiedade e evitar o contato com o meio externo.

E por último a estratégia de enfrentamento utilizada pelos usuários de substâncias psicoativas que apareceu durante as duas entrevistas foi à mudança de rota, evitar frequentar os locais em que existia o uso da substância ou onde se encontravam os amigos de uso, sendo citada por dois participantes.

Durante a segunda entrevista um dos pontos comentados pelos participantes foi à tentativa de se conseguir manter o prazer que o uso do crack proporcionava por meio de outros meios, como o não uso da medicação ou o uso de outras drogas, sendo que na maioria das vezes ocorria o não uso da medicação seguido pelo uso de outras drogas, principalmente o álcool.

\begin{tabular}{|c|l|}
\hline $\begin{array}{c}\text { Possibilidade da manutenção do } \\
\text { prazer do uso }\end{array}$ & \multicolumn{1}{c|}{$\mathbf{2}^{\mathbf{a}}$ entrevista } \\
\hline Interrupção da medicação & $\begin{array}{l}\text { "A psicóloga vai me xingar (por não ter feito o uso } \\
\text { da medicação), mas eu queria ter uma vida normal." } \\
\text { FAG35 }\end{array}$ \\
\hline Uso de outras drogas & $\begin{array}{l}\text { "Perdi o pacote (de medicação) da semana inteira... } \\
\text { fiz uso duas vezes da droga e do álcool todos os } \\
\text { dias." VJF44 }\end{array}$ \\
\hline
\end{tabular}




\begin{tabular}{|c|l|}
\hline Sonhar/ lembrar do uso & $\begin{array}{l}\text { "Porque eu não quis mesmo, a medicação faz a } \\
\text { gente dormir e eu não queria dormir, eu queria sair } \\
\text { de noite e beber, então não ia dar certo não." } \\
\text { FAG35 }\end{array}$ \\
\hline $\begin{array}{l}\text { "Tenho (vontade) não, mas às vezes ainda dá... eu } \\
\text { sonho às vezes" RAS31 } \\
\text { "Nesse momento não (não tem vontade), } \\
\text { esporadicamente... Muito esporadicamente vem a } \\
\text { ideia, mas não chega a ser uma vontade não é mais } \\
\text { uma lembrança" HJM47 }\end{array}$ \\
\hline
\end{tabular}

QUADRO 7- Possibilidade de manutenção do prazer do uso

O uso da medicação pode ser encarado como um meio de controle, de não se ter uma vida normal ou um limitador da diversão.

Um fato comentando também por dois indivíduos durante a segunda entrevista foi à lembrança do crack, como se "sentissem o gosto" ou através de sonhos. Portanto neles a vontade do uso da substância pareceu permanecer latente.

A abstinência e a redução do uso são dificultadas pelos fatores já citados, como ambiente em que o indivíduo circula, os amigos e emoções, enfim tanto fatores intrapessoais quanto interpessoais. Dos 17 entrevistados iniciais, apenas seis continuaram o tratamento no CAPS ad, sendo que desses apenas dois relatam manter abstinência por mais de três meses.

Todos os seis tiveram reduções no padrão de uso, sendo que passaram do uso diário para a abstinência ou uso nos fins de semana ou quinzenal.

\section{E. PERCEPÇÕES DE SI E PERCEPÇÃO DOS OUTROS}

O quadro 8 resume as falas dos participantes sobre a autopercepção na primeira e na segunda entrevista realizada após três meses. 


\begin{tabular}{|c|c|c|}
\hline Participante & $\mathbf{1}^{\mathbf{a}}$ entrevista & $2^{a}$ entrevista \\
\hline FAG35 & $\begin{array}{l}\text { "A FAG era uma pessoa legal, que } \\
\text { tinha sonhos muito bons... queria } \\
\text { dançar." }\end{array}$ & $\begin{array}{l}\text { "Eu sempre acho que sirvo } \\
\text { para alguma coisa." }\end{array}$ \\
\hline NCM17 & $\begin{array}{l}\text { "De mim? Uma pessoa boa que } \\
\text { inventou a miséria. Eu tenho uma } \\
\text { ilusão... um sonho." }\end{array}$ & $\begin{array}{l}\text { "Uma NCM sensível, } \\
\text { carismática" }\end{array}$ \\
\hline VJF44 & "É outra pessoa. Bem melhor...". & $\begin{array}{l}\text { "Eu acho que eu dei uma } \\
\text { melhorada de } 70 \text { a } 80 \% \text {." }\end{array}$ \\
\hline RAS31 & $\begin{array}{l}\text { "Ahh eu acho assim...que eu estou } \\
\text { impossibilitado, acho que não } \\
\text { consigo... eu preciso de um para ver se } \\
\text { eu consigo." }\end{array}$ & $\begin{array}{l}\text { "Eu não queria me dar mais } \\
\text { valor não, porque não tenho } \\
\text { valor nenhum." }\end{array}$ \\
\hline VAG52 & "Um cara solitário... abandonado" & $\begin{array}{l}\text { "Um cara isolado, todos me } \\
\text { isolaram." }\end{array}$ \\
\hline HJM47 & $\begin{array}{l}\text { "O que posso dizer que é relevante? } \\
\text { Uma pessoa normal que tem objetivos } \\
\text { comuns... ficar milionário..." }\end{array}$ & $\begin{array}{l}\text { "Eu já me dou o respeito } \\
\text { suficiente senão vira } \\
\text { egocentrismo." }\end{array}$ \\
\hline WEN28 & $\begin{array}{l}\text { “... eu falo que eu sou um guerreiro, } \\
\text { porque não é fácil não. Eu tenho uma } \\
\text { família, um trabalho, sou um cara } \\
\text { bacana com o coração bom! O único } \\
\text { problema é essa droga, acaba com } \\
\text { tudo, acaba com a família, deixa } \\
\text { sequela mesmo.” }\end{array}$ & $\begin{array}{l}\text { Não respondeu por estar em } \\
\text { uma clínica psiquiátrica }\end{array}$ \\
\hline JMMS41 & $\begin{array}{l}\text { "Eu tenho que aprender muito ainda. } \\
\text { Eu to em processo de recuperação } \\
\text { ainda. Usei droga por muito tempo." }\end{array}$ & $\begin{array}{l}\text { Não respondeu por estar em } \\
\text { umar comunidade } \\
\text { terapêutica }\end{array}$ \\
\hline MRAF33 & $\begin{array}{l}\text { "Agora?! Agora eu penso que eu sou... } \\
\text { agora eu sei o que é viver... antes eu } \\
\text { não sabia." }\end{array}$ & $\begin{array}{l}\text { Não respondeu por estar em } \\
\text { umarantidade } \\
\text { terapêutica }\end{array}$ \\
\hline WLM41 & $\begin{array}{l}\text { "Sou uma pessoa assim, sereno, calmo, } \\
\text { tranquilo. Não me envolvo em } \\
\text { problemas alheios. Se eu puder ajudar } \\
\text { eu ajudo." }\end{array}$ & Abandonou o tratamento \\
\hline GDR49 & $\begin{array}{l}\text { "De mim hoje? Uma pessoa que já foi } \\
\text { muito sofrida que está em recuperação } \\
\text { e que enxerga as coisas." }\end{array}$ & Abandonou o tratamento \\
\hline DAQ28 & $\begin{array}{l}\text { "Eu também sofri muito já, também } \\
\text { por causa de droga, pegar droga } \\
\text { "fiada" com os outros e até mesmo } \\
\text { mexer com drogas dos outros. Apanhar } \\
\text { muito, quase morrer. Penso em } \\
\text { melhorar geral, por completo." }\end{array}$ & Abandonou o tratamento \\
\hline MAL45 & $\begin{array}{l}\text { "Acho que o MAL é o MAL real } \\
\text { agora, firmado psicologicamente, que }\end{array}$ & Abandonou o tratamento \\
\hline
\end{tabular}




\begin{tabular}{|c|c|c|}
\hline & $\begin{array}{l}\text { antes tinha que trabalhar e cuidar de } \\
\text { família... hoje eu não vejo a droga me } \\
\text { ajudando em nada." }\end{array}$ & \\
\hline RCR54 & $\begin{array}{l}\text { "Uai, no ponto de vista eu ainda não } \\
\text { sou o que quero ser ainda não, mas não } \\
\text { sou o que era também mais não, tá } \\
\text { entendendo?" }\end{array}$ & Abandonou o tratamento \\
\hline CAGL29 & $\begin{array}{l}\text { "Uma pessoa que caiu em um poço } \\
\text { muito fundo e que não saiu dele ainda } \\
\text { não, tá tentando sair dele." }\end{array}$ & Abandonou o tratamento \\
\hline EALS27 & $\begin{array}{l}\text { "Tenho muita coisa para falar do que } \\
\text { passei da minha vida. Muita coisa de } \\
\text { droga e esses trem... de morte e cadeia. } \\
\text { Já passei uma fase muito ruim da } \\
\text { minha vida." }\end{array}$ & $\begin{array}{l}\text { Recluso em uma } \\
\text { penitenciaria (mas em } \\
\text { tratamento medicamento no } \\
\text { CAPS ad) }\end{array}$ \\
\hline
\end{tabular}

Quadro 8: autopercepção

Durante a primeira entrevista os participantes foram questionados em sua autopercepção, sendo que 16 falaram sobre o tema, notou-se que apenas quatro (25\%) tinham uma visão negativa e de abandono, os demais expressaram percepções que variaram de boa, normal a alguém que sofreu muito e tem uma perspectiva de melhora (de mudança do estado atual).

Três meses após, aqueles em que foi possível realizar a segunda entrevista, ao todo foram seis os que continuaram o tratamento, observou-se certa melhora na autopercepção de quatro participantes, mas esses relataram que ainda precisavam se dedicar mais para alcançarem suas metas.

Dos quatro participantes que tinham uma visão negativa, dois mudaram sua autopercepção para positiva durante a segunda entrevista.

Sete $(43,75 \%)$ participantes que tinham expectativas de melhora da autopercepção não estavam em tratamento durante a segunda entrevista, sendo que desses sete, dois foram para clínicas fechadas para tratamento.

O quadro a seguir (quadro 9) trás a percepção sobre a opinião alheia, em dois momentos, primeira e segunda entrevistas. 


\begin{tabular}{|c|c|c|}
\hline Participante & $1^{a}$ entrevista & $2^{a}$ entrevista \\
\hline FAG35 & $\begin{array}{l}\text { "Eu não sei não... Eu não sou uma } \\
\text { pessoa que importa com o que os } \\
\text { outros pensam sobre mim ou deixaram } \\
\text { de pensar. Se dá vontade de fazer } \\
\text { alguma coisa eu vou e faço. Eu quero } \\
\text { saber de mim, pensar por mim. Eu não } \\
\text { ligo para os outros não..." }\end{array}$ & $\begin{array}{l}\text { "Acho que estão todos } \\
\text { gostando! Que todos meus } \\
\text { amigos estão apoiando que eu } \\
\text { agora resolvi parar mesmo e } \\
\text { voltar a viver." }\end{array}$ \\
\hline NCM17 & "Uma otária!" & $\begin{array}{llll}\text { "Não levo } & \text { nada } & \text { em } \\
\text { consideração." } & & \end{array}$ \\
\hline VAG52 & $\begin{array}{l}\text { "Deixa-me pensar aqui... é que eles } \\
\text { roubam e eu não roubo, eles tem } \\
\text { inveja de mim, querem que eu vá } \\
\text { preso. Eu falo para a minha mãe: } \\
\text { "Mãe, quando a senhora morrer a } \\
\text { senhora pode ter certeza que na sua } \\
\text { família nunca teve ladrão." Eu que } \\
\text { poderia ter sido ladrão por causa da } \\
\text { droga, mais não tem nenhum ladrão na } \\
\text { família." }\end{array}$ & $\begin{array}{l}\text { "Ninguém liga para mim, } \\
\text { ninguém me dá nada." }\end{array}$ \\
\hline HJM47 & $\begin{array}{l}\text { "De alguém?! Só Deus, porque eu } \\
\text { teria que ter alguém, pela lógica, que } \\
\text { tivesse condição de me ensinar e pelo } \\
\text { que estou vendo está todo mundo no } \\
\text { mesmo barco que eu, tentando } \\
\text { aprender, então eu não vejo muita } \\
\text { chance não." }\end{array}$ & $\begin{array}{l}\text { "Apoio-me na opinião de } \\
\text { várias pessoas, eu me apoio } \\
\text { em sua opinião, na opinião da } \\
\text { psicóloga, na do pastor da } \\
\text { igreja ou na do padre. Apoio- } \\
\text { me em várias opiniões que eu } \\
\text { ache valida, mantendo meu } \\
\text { espírito crítico." }\end{array}$ \\
\hline VJF44 & $\begin{array}{l}\text { "Uai, pelo menos em todo lugar que } \\
\text { eu vou o povo gosta de mim. Graças a } \\
\text { Deus eu não tenho inimigo nenhum, } \\
\text { nem aqui nem em Nova Serrana(outro } \\
\text { município)." }\end{array}$ & Não falou sobre o tema \\
\hline RAS31 & $\begin{array}{l}\text { “... acho que as pessoas vêm te ajudar } \\
\text { por dó... por dó. E respeito assim eu } \\
\text { acho que ninguém me respeita não." }\end{array}$ & Não falou sobre o tema \\
\hline WEN28 & $\begin{array}{l}\text { "Eu penso é em mim mesmo... eu não } \\
\text { importo com o que os outros pensam } \\
\text { não." }\end{array}$ & $\begin{array}{l}\text { Não respondeu por estar em } \\
\text { uma Clínica psiquiátrica }\end{array}$ \\
\hline MRAF33 & $\begin{array}{l}\text { "Escuto porque pode ter alguma coisa } \\
\text { de útil, mais na minha vida não faz a } \\
\text { menor diferença...". }\end{array}$ & $\begin{array}{l}\text { Não respondeu por estar em } \\
\text { uma comunidade terapêutica }\end{array}$ \\
\hline
\end{tabular}




\begin{tabular}{|c|c|c|}
\hline JMMS41 & $\begin{array}{l}\text { "...os vizinhos tem até medo de mim. } \\
\text { Os vizinhos nem conversam comigo } \\
\text { não, dizem que não bato da cabeça, já } \\
\text { tive problema de traficante indo lá na } \\
\text { porta de casa me cobrando e eu tendo } \\
\text { que fugir pelo fundo, chegar armado, } \\
\text { polícia lá dentro de casa, jogando tudo } \\
\text { no chão, caçando droga, caçando } \\
\text { arma... E hoje em dia uns até acham } \\
\text { que eu melhorei bastante em vista do } \\
\text { que eu era e outros até hoje tem } \\
\text { preconceito comigo, não conversam } \\
\text { comigo..." }\end{array}$ & $\begin{array}{l}\text { Não respondeu por estar em } \\
\text { uma comunidade terapêutica }\end{array}$ \\
\hline WLM41 & $\begin{array}{l}\text { "O que os outros pensam eu não me } \\
\text { importo. Como dizem: falem bem ou } \\
\text { mal"." }\end{array}$ & Abandonou o tratamento \\
\hline GDR49 & $\begin{array}{l}\text { "Depende da pessoa, tipo a psicóloga } \\
\text { eu escuto porque ela estudou o ser } \\
\text { humano e ela também aprende } \\
\text { comigo, é tudo uma troca. Mais agora } \\
\text { eu vou escutar um corrupto, um } \\
\text { ladrão? alguém que não tem Deus no } \\
\text { coração. Tudo depende." }\end{array}$ & Abandonou o tratamento \\
\hline DAQ28 & $\begin{array}{l}\text { "ahh, olha o "Noia”, aquele cara ali? } \\
\text { Não anda com ele não, que ele rouba } \\
\text { casa dos outros, tudo isso." }\end{array}$ & Abandonou o tratamento \\
\hline RCR54 & $\begin{array}{l}\text { "Ahh eu não sei... Pelo menos ali onde } \\
\text { eu moro ali, tem cinco anos e eles } \\
\text { nunca viram um maconheiro beirar ali, } \\
\text { nunca viram beirar boteco, porque eu } \\
\text { detesto, eu entro em boteco só para } \\
\text { comprar cigarro. Então como se diria a } \\
\text { vizinhança lá não tem o que se queixar } \\
\text { de mim lá não. A não ser o dono da } \\
\text { casa que de vez em quando sente um } \\
\text { cheirinho diferente lá, mas podem } \\
\text { sentir eu não ligo não..." }\end{array}$ & Abandonou o tratamento \\
\hline CAGL29 & $\begin{array}{l}\text { "Algumas opiniões são boas e a gente } \\
\text { tem que pegar para a gente. Mas } \\
\text { preocupar com o que estão pensando } \\
\text { sobre mim isso eu não me preocupo. } \\
\text { Não adianta, por exemplo, eu vou } \\
\text { olhar para você e vou pensar assim: “ } \\
\text { será o que ela tá pensando de mim? } \\
\text { Será que ela foi com a minha cara? } \\
\text { Será que ela gostou de mim?"Ai eu }\end{array}$ & Abandonou o tratamento \\
\hline
\end{tabular}




\begin{tabular}{|l|l|l|}
\hline & $\begin{array}{l}\text { vou ficar com aquilo na cabeça e fica } \\
\text { martelando aquilo na cabeça, então eu } \\
\text { não procuro nem pensar." }\end{array}$ & \\
\hline EALS27 & $\begin{array}{l}\text { "Pensam nada não. Pararam de falar! } \\
\text { Eu não to usando mais." }\end{array}$ & $\begin{array}{l}\text { Recluso em uma penitenciaria } \\
\text { (mas em tratamento } \\
\text { medicamentoso no CAPS ad) }\end{array}$ \\
\hline
\end{tabular}

Quadro 9 - Percepção sobre a opinião alheia

Quando questionados inicialmente sobre como percebiam a visão do outro, dos que responderam a esse questionamento (15 participantes), sete (46,7\%) afirmaram não se importarem com a opinião alheia e cinco $(33,3 \%)$ manifestaram a existência de algum tipo de preconceito. Apenas dois (13,3\%) participantes levavam em consideração a forma como eram percebidos por terceiros, mas de forma seletiva (pessoas que consideravam significativas) e um participante acreditava que não existia preconceito ou indiferença.

$\mathrm{Na}$ segunda entrevista, dos quatro que responderam ao questionamento, onze participantes por não estarem mais vinculados ao serviço, não puderam expressar sua opinião na segunda entrevista, um (25\%) relatou não considerar a opinião alheia (mesma resposta na primeira entrevista), um relatou a existência de preconceito (25\%), sendo que na primeira entrevista o participante também a notava e dois relataram levar em consideração (50\%), sendo que um de maneira seletiva. Os dois que afirmaram levar em consideração a opinião mesmo que se forma seletiva, tiveram uma melhora da percepção já que na primeira entrevista haviam relatado não levarem em consideração a opinião de nenhuma pessoa.

\section{F.FONTES DE APOIO}

Uma das questões abordadas foi à maneira como o indivíduo percebia a fonte de apoio e como ele a caracteriza. Essa categoria foi subdividida em percepção quanto à fonte de apoio: dos familiares, vizinhos, instituições, entidade religiosa e dele próprio e se essa era percebida como suficiente para o participante ou não. 


\begin{tabular}{|c|c|c|}
\hline $\begin{array}{l}\text { Percepção sobre } \\
\text { as fontes de apoio } \\
\quad \text { (suficientes) }\end{array}$ & Participante & Número \\
\hline $\begin{array}{c}\text { Família (de } \\
\text { maneira geral) }\end{array}$ & $\begin{array}{l}\text { "Eles (família) querem que eu vá para lá(cidade da } \\
\text { família), eles sempre me apoiaram, sempre } \\
\text { quiseram que eu melhorasse, nunca me } \\
\text { abandonaram, sempre me dando força para sair, } \\
\text { sempre me ajudando." FAG35 }\end{array}$ & 4 partic. \\
\hline Mãe & $\begin{array}{l}\text { "Moro com a minha mãe, ela me dá apoio, dá até } \\
\text { quando não está podendo." RAS31 }\end{array}$ & 4 partic. \\
\hline Avó & $\begin{array}{l}\text { "Ela (avó) me ajuda! Me dá conselhos, fala para } \\
\text { eu largar." NCM17 }\end{array}$ & 1 partic. \\
\hline Irmãos & $\begin{array}{l}\text { "O que me acolhe é meu irmão mais novo... Eu } \\
\text { me internei justamente por ele (irmão). Ele disse } \\
\text { que não me aguentava ver nessa vida mais, ou eu } \\
\text { largava ou ele agarrava no crack comigo ou se } \\
\text { matava." WLM41 }\end{array}$ & 2 partic. \\
\hline Esposa & $\begin{array}{l}\text { "Minha esposa, a gente já tem um tempo de } \\
\text { casado e ela tem me apoiado muito." MAL45 }\end{array}$ & 1 partic. \\
\hline Marido & $\begin{array}{l}\text { "Eles também (se referindo à família), mas eles } \\
\text { não são daqui. Então quem me ajuda mais é meu } \\
\text { marido."FAG35 }\end{array}$ & 1 partic. \\
\hline Filhos & $\begin{array}{l}\text { "Eles(filhos) me deram apoio, falaram para eu } \\
\text { largar, mas quem aguenta um drogado dentro de } \\
\text { casa?” GDR49 }\end{array}$ & 2 partic. \\
\hline Vizinhos & $\begin{array}{l}\text { "Eu tive um pequeno acidente, dei um soco no } \\
\text { vidro, daí elas (vizinhas) me socorreram." FAG35 }\end{array}$ & 2 partic. \\
\hline Instituições & $\begin{array}{l}\text { "Na verdade é expandir a mente... toda vez que eu } \\
\text { venho aqui (CAPSad) eu vejo um lado que eu não } \\
\text { estava vendo, ai me ajuda bastante" MRAF33 } \\
\text { "Ultimamente eu estou indo nos Narcóticos } \\
\text { anônimos, eu tenho um padrinho, eu tenho } \\
\text { desabafado muito com ele."MAL45 }\end{array}$ & 2 partic. \\
\hline Religião & $\begin{array}{l}\text { "Eu tenho esse costume meio esquisito, eu } \\
\text { converso com Deus... isso me ajuda }\end{array}$ & 3 partic. \\
\hline
\end{tabular}




\begin{tabular}{|l|l|l|}
\hline & bastante...”HJM47 & \\
\hline Ele próprio & $\begin{array}{l}\text { “Apoio? O apoio que a gente deve ter de verdade } \\
\text { é da gente mesmo, o equilíbrio da gente vem da } \\
\text { gente mesmo não é algo externo.” HJM47 }\end{array}$ & 1 partic. \\
\hline
\end{tabular}

QUADRO 10- Percepção sobre as fontes de apoio tidas como suficientes

\begin{tabular}{|c|c|c|}
\hline $\begin{array}{l}\text { Percepção de } \\
\text { apoio } \\
\text { (insuficiente) }\end{array}$ & Participante & Número \\
\hline Família em geral & $\begin{array}{l}\text { "Eu estou do jeito que eu adoro... Longe! A minha } \\
\text { família é muito complicada são boas pessoas, } \\
\text { mas..." HJM47 }\end{array}$ & 2 partic. \\
\hline Irmão & $\begin{array}{l}\text { "Eles (irmãos) queriam me internar. Ai eu disse } \\
\text { "de jeito nenhum, quero ficar é em casa." Uma } \\
\text { vez eles me internaram no hospital psiquiátrico e } \\
\text { eu estava é ficando louco lá dentro." VAG52 }\end{array}$ & 2 partic. \\
\hline Pai & “Ele (pai) não liga para mim não" NCM17 & 6 partic. \\
\hline Mãe & $\begin{array}{l}\text { "Ela (mãe) já esteve nesse internato aqui, minha } \\
\text { filha! Minha mãe mexe com isso também, não } \\
\text { posso julgar ela não, mas ela mexe.” NCM17 }\end{array}$ & 2 partic. \\
\hline Ex-esposa & $\begin{array}{l}\text { "Ela(Ex- esposa) anda bebendo. Ela pediu para } \\
\text { enviar dinheiro para comprar o material escolar do } \\
\text { menino, mas para ela eu não mando não. Ela gasta } \\
\text { o dinheiro com bebida e com o outro menino." } \\
\text { VJF44 }\end{array}$ & 2 partic. \\
\hline Ex-marido & $\begin{array}{l}\text { "Perdi eles (filhos) por causa das drogas. Ele (ex- } \\
\text { marido) os tirou de mim." CAGL29 }\end{array}$ & 1 partic. \\
\hline
\end{tabular}




\begin{tabular}{|c|l|l|}
\hline Filho & $\begin{array}{l}\text { "Com a minha família é bom. Com meu filho } \\
\text { (Filho de 21 anos com a primeira esposa) é eu } \\
\text { para cá e ele para lá."JMMS41 }\end{array}$ & 1 partic. \\
\hline Esposa & $\begin{array}{l}\text { "Não, apoiava assim... não se isso era ajudar... } \\
\text { Quando a gente estava melhor ela (esposa) me } \\
\text { dava dinheiro para usar quando eu não tinha. Ai, } \\
\text { eu não sei se apoiava ou prejudicava." RCR54 }\end{array}$ & 1 partic. \\
\hline
\end{tabular}

QUADRO 11: Percepção sobre as fontes de apoio tidas como insuficientes

Sobre a percepção do apoio da família, todos (17) os participantes expressaram sua percepção, embora parecesse existir verta ambivalência, pois houve 15 entrevistados para quem o apoio recebido foi percebido como suficiente e satisfatório, sendo que os mesmos participantes citaram mais de um membro da família, e apareceu que para os 17(total), o apoio foi apresentado como limitado ou insuficiente.

Dentre os familiares citados como principais fontes de apoio a mãe foi mencionada por quatro participantes, seguido pelos filhos e irmãos com dois participantes. A figura paterna não apareceu nas falas dos participantes como fonte de apoio, sendo mencionado por seis entrevistados como fonte limitada de apoio, sendo que quatro relataram terem sido abandonados pelo pai e dois que perceberam que mesmo tendo a figura paterna, essa não oferecia apoio.

Para dois entrevistados os familiares deveriam possuir um entendimento acerca do problema ou um grau de comprometimento maior com o tratamento. Para um participante mesmo que os familiares tivessem esse entendimento, o grau de cobrança por parte desses poderia chegar a ser prejudicial ou percebida apenas como "encenação de um papel”.

“... Esse é aquele pessoal (família) que fez o curso, deixa eu te explicar, o curso do amor exigente, então eles tendem a ter um nível de cobrança mais alto em relação a minha pessoa e isso é perceptível, tão perceptível que eu conhecendo as pessoas, tem umas que conheço há 47 anos, eu noto que eles não estão sendo eles mesmos, estão desempenhando um papel... uma personagem, entendeu?!" HJM47

Outra fonte de apoio citada foram os vizinhos, mencionado por dois entrevistados. O CAPS ad foi citado por um entrevistado, assim como os narcóticos anônimos. A religião 
apareceu na fala de três participantes como fundamental para a recuperação. E por último teve-se um entrevistado que citou a si próprio como principal fonte de apoio.

Outro fator importante quando se avalia os determinantes interpessoais são os amigos, se esse indivíduo os possui e que tipo de amizade é construída. A seguir apresenta-se um resumo da percepção da relação de amizade dos participantes.

\begin{tabular}{|c|c|c|}
\hline $\begin{array}{c}\text { Percepção sobre } \\
\text { amizade }\end{array}$ & Participante & Número \\
\hline Não tem amigos & $\begin{array}{l}\text { "Eu tinha amizade só no inicio, eu sou assim... eu } \\
\text { não tenho muito contato com as pessoas não. } \\
\text { Quando eu comecei a usar as drogas eu passei a } \\
\text { conhecer pessoas do meu jeito, do meu estilo, } \\
\text { pessoas como eu que não roubavam, que } \\
\text { compravam através do trabalho, eu nunca roubei } \\
\text { nem nada" RAS31 } \\
\text { "Nunca fui de ter amigos, andar em turma" } \\
\text { RCR54 } \\
\text { "Quando a gente usa não tem muitos amigos } \\
\text { sérios" EALS27 }\end{array}$ & 7 partic. \\
\hline Amigos de uso & $\begin{array}{l}\text { "Nesse meio tempo eu fui fazendo amizade (de } \\
\text { uso de crack) porque está todo mundo usando e } \\
\text { não tem preconceito. Mas, você perde muita coisa, } \\
\text { família e amigos de infância" CAGL29 } \\
\text { "Tinha aqueles amigos de crack, que diziam que } \\
\text { eram meus amigos, mas não eram nada..." } \\
\text { WLM41 }\end{array}$ & 5 partic. \\
\hline Desconfiança & $\begin{array}{l}\text { "Eu tenho contato com pessoas de maneira } \\
\text { saudável, não confio em ninguém, graças a Deus ! } \\
\text { A amizade depende, a pessoa se dedica a pessoa } \\
\text { enquanto ela se identifica com a imagem que ela } \\
\text { tem de você, no momento que ele usou crack, } \\
\text { nossa!" HJM47 }\end{array}$ & 1 partic. \\
\hline $\begin{array}{l}\text { Amigos de antes } \\
\text { do uso }\end{array}$ & $\begin{array}{l}\text { "Não posso dizer isso, não foram eles (amigos de } \\
\text { antes do uso) que se afastaram, foi eu que me } \\
\text { afastei... eu que fui até a droga, não posso culpar } \\
\text { eles." MRAF33 }\end{array}$ & 4 partic. \\
\hline
\end{tabular}

QUADRO 12- Percepção dos participantes sobre amizade 
Todos os entrevistados falaram sobre a ideia de amizade e quais eram esses amigos. Para sete $(41,2 \%)$ entrevistados a ideia de amizade não existia, relataram não gostarem ou evitarem o vínculo, para cinco $(29,4 \%)$ à amizade estava vinculada ao uso de crack, sendo os amigos apenas de uso e quando faziam tentativas de abstinência ou quando se mantinham abstêmios esses amigos “desapareciam”. Quatro $(23,5 \%)$ participantes relataram a perda da amizade de antes do uso devido ao envolvimento com o crack e um $(5,9 \%)$ participante falou sobre a importância de se conviver com as pessoas, mas evitar o estreitamento das relações.

Outro item citado por um entrevistado foi o meio em que o indivíduo mora ou circula como facilitador ou não para a obtenção da SPA. O que se percebeu na fala foi à facilidade de obtenção e a disseminação dos pontos de venda.

"O ambiente que eu vivi mexia e isso favoreceu eu mexer também. Eu resisti por um tempo, o povo ia jogar bola ou no fliperama e oferecia e eu dizia que não mexia com isso não e nem bebia por medo de passar mal, mas falavam que eu dava uma de gostoso. Só de você ver as pessoas usando você já está sendo influenciado, se você não visse... mas a partir do momento que você usa é porque você foi influenciado.” RAS31

Assim para esse usuário o início do uso das Substâncias psicoativas se deve a influência do meio, do ver o outro usar e da influência de amigos. 


\section{DISCUSSÃO}

O estudo demonstrou que os pacientes atendidos pelo CAPS ad de um município de Minas Gerais são homens, jovens adultos, solteiros, que estudaram até o ensino fundamental e se autorreferiram pardos. Esses dados corroboram com estudos nacionais que demonstram que a grande maioria dos usuários é do sexo masculino e baixo nível escolar (FIOCRUZ, 2014; OLIVEIRA, 2011; HORTA et al, 2011; MOURA et al, 2014; SCHEFFER; PASSA; ALMEIDA, 2010). A baixa escolaridade pode estar relacionada ao uso precoce de SPA, que influência na evasão escolar (SCHEFFER; PASSA; ALMEIDA, 2010).

O estudo atual também sinalizou que o início do uso de substâncias psicoativas ocorreu na adolescência (com 14-15 anos) através do uso de substâncias lícitas. Isso corrobora com outros estudos que apontam o início precoce de uso de qualquer substância psicoativa como fator de risco para o uso de crack e cocaína na idade adulta, sendo o uso do tabaco a droga inicial de escolha (EPSTEIN et al, 2010).

Em relação ainda a idade de início do uso de tabaco e álcool por usuários de crack dados mostram ser com 13,32 anos e 13,90 anos, respectivamente (BALBINOT et al ,2011). Portanto, idade próxima a dos participantes deste estudo.

A família parece não perceber o uso do álcool como uma droga, que pode trazer prejuízos à formação psicossocial da criança ou adolescente e influenciar no início do uso de outras SPA (PAULA et al, 2014). A primeira droga ilícita utilizada pelos participantes foi à maconha, fato que é citado também por estudos (PEDROSO; KESSLER; PECHANSKY, 2013).

Em estudo recente Abdalla et al (2014), fala sobre o gênero masculino ter uma tendência maior de 4,4 de fazer o uso de SPA do que as mulheres. O estado civil solteiro também aparece como predominante entre a população que faz uso de SPA, uma possível explicação seria devido ao afrouxamento dos laços familiares que acomete muitas vezes o usuário de droga (FIOCRUZ, 2014). Quanto à raça, pesquisa aponta que os pardos e negros ainda são a maioria dos usuários, fato que pode ocorrer devido a essa população estar em maior contexto de vulnerabilidade social (FIOCRUZ, 2014). 
No presente estudo, apenas três mulheres foram entrevistadas, mesmo que o número seja menor parece que essas são mais susceptíveis a dependência (ABDALLA et al, 2014), e o tratamento surte efeito mais rapidamente no homem do que na mulher (MCKAY et al, 2013). Além de serem estigmatizadas até mesmo entre os usuários de crack, por acreditarem que o uso de SPA é algo ligado ao gênero masculino (FIOCRUZ, 2014). Assim, o fato de ter poucas mulheres no estudo, pode ser explicado pelo constrangimento e estigma sofridos.

O uso do sexo em troca de SPA (situação relatada nesta pesquisa por duas das três entrevistadas) também é relatada pela literatura (RODRIGUES et al, 2012, CHAVES et al, 2011). Portanto este estudo corrobora a importância da oferta tratamentos específicos para esse grupo.

A média de idade foi de 36, 9 anos, média maior do que a apresentada em estudo nacional cuja média foi de 30,28(FIOCRUZ, 2014) e de outros estudos nacionais em que a média variou de 28 a 31 anos (MOURA et al, 2014; SCHEFFER; PASSA; ALMEIDA, 2010). Quanto à fonte de renda mais da metade (53\%) referiram possuir alguma, sendo que cinco participantes recebiam benefício da previdência social devido aos problemas e tratamento para SPA. O que difere da pesquisa nacional sobre o uso de crack (2014) em que a principal fonte de renda seriam os trabalhos esporádicos ou autônomos.

Sobre o recebimento de salários, Duff e Baldwin (2013) assinalam que os usuários de SPA gastam o dinheiro que recebem com drogas, o mesmo foi encontrado neste estudo. Já Decorte (2001) considera o fato de ter alguma fonte de renda como um fator de proteção, pois melhora a autoestima do indivíduo. Ainda sobre recursos financeiros, um estudo revelou que a grande maioria dos usuários de crack não possui vínculo empregatício, o que corrobora com a presente pesquisa, já que como mencionado, uma parcela dos entrevistados recebe benefícios (SANCHEZ; NAPPO, 2002).

A religião apareceu como importante fonte de conforto para 76,5\% dos participantes seja a religião evangélica ou a católica, pois apareceu com o mesmo número de frequentadores. Não se pode afirmar se tal dado é anterior ou posterior à passagem desses usuários por clínicas de reabilitação de caráter religioso. Estudos demonstram que ter uma religião auxilia na recuperação, pois dá um sentido a vida, substituindo a rotina centrada nas drogas, vincula o indivíduo a uma comunidade, em que o uso de drogas não é bem aceito 
(RIGOTO; GOMES 2002; PEDROSO; KESSLER; PECHANSKY, 2013; RAUPP; MILNITISKY-SAPIRO, 2008). A religião também aparece como fator protetor para o não uso de drogas, com indícios de que quanto maior a crença religiosa menor a probabilidade do inicio do uso de SPA (DALGALLORRANDO, 2004; GOMES et al, 2013). Esse fato pode estar ligado a internalização de valores tradicionais, fazendo com que o indivíduo tenha menor tolerância para "desvios" sociais não permitidos pela comunidade religiosa (EDLUND et al, 2010; GOMES et al, 2013). Outro aspecto que pode contribuir é o envolvimento do indivíduo usuário em trabalhos voluntários que também é uma prática habitual em pessoas religiosas, afastando- as de contatos sociais de risco (GOMES et al, 2013).

Sobre o número de recaídas 53\% dos participantes relataram terem tido de 1-3 recaídas, seguido por $41,2 \%$ que relataram já terem tido mais de cinco episódios. A recaída é uma ocorrência esperada em um dado momento do tratamento e da vida do sujeito. Quase metade $(45,4 \%)$ dos pacientes que realizam tratamento para dependência do crack recai em um período de seis meses (PEDROSO; KESSLER; PECHANSKY, 2013), e a realidade das internações de dependentes químicos tem evidenciado que $47 \%$ dos usuários de crack não apresentaram melhoras ou permaneceram na mesma situação após um ano de internação, e desses, $10 \%$ morreram e 7\% foram presos (LARANJEIRA et al, 1998).

O tratamento mediante a abordagem da prevenção de recaída demonstrou através de estudo a redução do uso de drogas, porém mostrou que ainda há limitações, uma vez que o comportamento não foi mantido após quatro meses, fato aparentemente relacionado à quebra do suporte terapêutico que era recebido pelos participantes dessa pesquisa (HSU; COLLINS; MARLATT, 2013). O mesmo foi observado no presente estudo em que participantes passaram por mais de um programa de recuperação, mas recaíram após a alta. $\mathrm{O}$ acompanhamento e suporte em longo prazo é fator importante para o sucesso, pois pouco se sabe do padrão de recaída após a alta dos pacientes (PEDROSO; KESSLER; PECHANSKY, 2013). Um tipo de acompanhamento pode ser o telefônico que se demonstrou eficaz, sendo que após seis meses de acompanhamento $65 \%$ dos usuários se encontravam abstinentes do crack (BISCH et al, 2011).

A obtenção da droga foi questionada e nenhum participante relatou o furto ou o roubo como maneira de sua obtenção. Os participantes ou faziam troca de objetos pessoais ou familiares pela substância ou utilizavam o salário. Isso também foi verificado em estudo 
nacional em que apenas 6,4\% dos entrevistados relaram envolvimento em atividades ilegais para a obtenção de crack (FIOCRUZ, 2014).

Quando o indivíduo experimenta a droga ele espera alcançar algo, como um estado de prazer ou desligamento ou até mesmo uma forma de enfrentamento de situações consideradas como insuportáveis (MARLLAT; WITKIEWITZM, 2009). No presente estudo os participantes responderam sobre as expectativas em relação ao uso de SPA, sendo que a principal foi poder lidar com acontecimentos, como perdas e sentimento de incapacidade perante eventos incontroláveis, esse achado corrobora com estudos que apontam as dificuldades dos usuários de SPA em lidar com frustrações, perdas e conflitos, assim a droga passa a ser um meio de lidar com a realidade não suportada (CARVALHO et al, 2011; KESSLER et al,2010; FACUNDO et al, 2011).

O uso das drogas apareceu também como forma de desligamento, de conseguir lidar com dores físicas e emocionais e como instrumento para "parar de pensar", dados que também aparecem na literatura (CARVALHO et al, 2011; RIGOTTO; GOMES, 2002, FACUNDO et al, 2011, HSU; COLLINS; MARLATT, 2013).

A ideia de não ficarem "viciados" e que o uso era apenas por curiosidade, também esteve presente no estudo, o que concorda com outro estudo que aponta que em média $63 \%$ dos usuários de drogas informaram terem iniciado o uso por curiosidade (DIAZ et al, 2009)

O uso específico para o lazer e para facilitar o contato interpessoal foi mencionado no estudo, à droga como algo que socializa que faz com que a pessoa pertença a algum lugar e se sinta desinibida aparece em outro estudo sobre a temática (FACUNDO et al, 2011).

Um participante mencionou que o uso de drogas estaria relacionado ao "erro de caráter", pois a crença de alguns pacientes e familiares de que o uso de drogas seria devido à personalidade, de ser algo ligado ao caráter, também foi mencionado em estudo (PEDROSO; KESSLER; PECHANSKY, 2013). Essa perspectiva aparece ainda em alguns programas de recuperação, principalmente de cunho religioso, como adotados em algumas comunidades terapêuticos, que utilizam o modelo moral de tratamento, embasado na moral cristã de que o indivíduo consegue mudar se esse tiver força de vontade e "fibra moral", caso ele não consiga, "o fracasso" seria devido a um erro de caráter do indivíduo (RAUPP; MILNITISKYSAPIRO, 2008). 
Outros fatores podem estar conectados a percepção de que o uso de drogas é algo predeterminado, como a vulnerabilidade neurobiológica e predisposição genética, tema muito discutido e pesquisado nos dias atuais (SCHEFFER; PASA; ALMEIDA,2010), em que o histórico familiar de uso de drogas ou transtorno do humor poderiam ser um fator determinante para o indivíduo fazer uso de SPA (PEDROSO; KESSLER; PECHANSKY, 2013; GABATZ et al, 2013).

Sobre os motivos para o uso, o mais citado foram os estados emocionais (11 participantes), sendo a raiva o sentimento mais relatado, a ansiedade e a sensação de vazio apareceram em segundo lugar, o que concorda com estudos em que sentimentos vivenciados pelos usuários de SPA como ansiedade, sensação de não ser útil ou de ser incapaz para mudanças de hábitos podem levar ao uso de drogas (ARAUJO; PEDROSO; CASTRO, 2011; BUCHELE; MARATI; RABELO, 2004; GABATZ et al, 2013; DOMINGOS, 2012).

O sentimento de tristeza, nessa pesquisa, por vezes denominado de "depressão" por alguns entrevistados, apareceu apenas na fala de um participante, porém aparece em outros estudos como importante fator para o uso de drogas, pois os afetos negativos são preceptores para o uso de SPA (DECORTE, 2011; BAKER; MORSE; SHERMAN, 1986; BUCHELE; MARATI; RABELO,2004; MCKAY et al,2013). Uma pesquisa descreve que 36\% das pessoas que fazem uso de SPA é devido a problemas de ordem emocional, como a depressão e a timidez (BUCHELE; MARATI; RABELO, 2004). Estudo também relata que usuários de drogas têm dificuldade em reconhecer as próprias emoções e lidar com elas (ARAUJO; PEDROSO; CASTRO, 2011). Isso mostra que os sentimentos têm um papel importante no uso de SPA e na manutenção das mesmas.

As situações vivenciadas também interferem no uso (sete participantes), na pesquisa tiveram o mesmo grau de importância às relações conjugais, a sensação de fracasso e a desocupação.

Estudo menciona que para 50\% dos usuários de droga os conflitos familiares são considerados fatores de risco (DIAZ et al, 2009), a pesquisa nacional sobre o uso de crack (FIOCRUZ, 2014) também aponta que para 29,15\% dos usuários, os problemas familiares ou perdas afetivas os motivaram ao uso de SPA, além das relações disfuncionais e as brigas de casal constante. Para $44 \%$ das pessoas que procuram o uso de SPA os problemas conjugais levam a uma recaída (BUCHELE; MARATI; RABELO, 2004). O que demonstra a importância 
de se tratar não apenas o indivíduo que faz uso de drogas, mas também seu companheiro (a) (ARAUJO et al,2011; CARVALHO et al, 2011),

A vivência de situações geradoras de fracasso também influência o uso de drogas. Locais de trabalho muito competitivos ou geradores de estresse acarretam sentimentos negativos que podem levar ao uso das drogas como uma alternativa para suportar o ambiente estressante e por vezes frustrante (YOUNG; WEST, 2010). O "não ter o que fazer" também influência, já que leva o indivíduo a lembrar dos efeitos da droga, servindo muitas vezes como motivador de cunho positivo para o uso, a esse respeito pesquisa aponta a inatividade como motivador para o uso de SPA (CARVALHO et al, 2011).

O meio em que o indivíduo circula é uma influência, sendo importante ao abordar o uso de drogas levar em consideração o meio social do indivíduo, perceber se há aceitação do uso, tendo em mente que o consumo de drogas envolve rituais sociais que são incorporados pelo indivíduo (DECORTE, 2001), um estudo também relata que existem locais propícios pra o uso, como lotes vagos e casas desabitadas (FACUNDO et al,2011)

$\mathrm{Na}$ pesquisa em questão os momentos de lazer e o uso de outras substâncias apareceram com a mesma relevância para o uso de substâncias psicoativas. Sobre os momentos de prazer os entrevistados (2) ligaram o fato de serem extrovertidos ao uso de SPA, outros (2) vincularam o uso às companhias.

A personalidade e o querer ser aceito pelo grupo acaba influenciando o uso de SPA. $\mathrm{Na}$ adolescência, época da vida que o indivíduo procura seu papel social, faz do uso de SPA um vínculo de solidariedade e pertencimento a um grupo (FACUNDO et al, 2011), além da influência dos amigos ser fator de uso importante (GABATZ et al,2013; ABDALA et al,2014), em estudo nacional 26,73\% dos entrevistados relataram ter iniciado o uso de crack devido a "pressão" dos amigos (FIOCRUZ, 2014). A extroversão foi mencionada por participantes deste estudo como expectativa de se divertir, mas em seguida o lazer se tornou motivo de manutenção do uso de drogas, tal resultado corrobora com dados do estudo de Young et al (2012). A ligação entre o lazer e o crack pode ser explicada pelo efeito imediato causado como euforia, energia aumentada e impulso sexual (CARROL; BALL,2010; CARROL; RAWSON,2009).

Outro motivo para o uso de crack seria o uso do álcool. O álcool já foi apontado neste estudo como "porta de entrada" para o início do uso de outras substâncias, por sua vez, 
no caso da manutenção do uso de crack, o etílico gera um gatilho para o uso do crack, cria-se um ciclo vicioso, pois o uso do álcool faz o indivíduo usar o crack, para maximizar os efeitos do crack e depois para se "acalmar" o álcool é utilizado novamente (GABATZ et al, 2013; MCKAY et al, 2013).

O uso de SPA durante o tratamento no CAPS ad também foi relatado pelos participantes, sendo o tabaco a substância mais utilizada, resultado confirmado em outros estudos que relatam que o uso de crack/ cocaína caminha conjuntamente com o do tabaco (FIOCRUZ, 2014; EPSTEIN et al, 2010; BALBINOT et al, 2011).

O tabaco ainda foi citado pelos participantes como a "droga mais difícil de largar", esse dado também aparece em outras pesquisas, os autores Baca e Yahne (2009) relatam o fato do uso de outras substâncias tornar mais difícil a interrupção do uso de tabaco, e que o tratamento para a abstinência do cigarro aumenta a probabilidade de abstinência de outras substâncias (PROCHASKA; DELUCCHI; HALL, 2004). Em outra direção estudo afirma que o uso do cigarro diminui a vontade de uso de outras substâncias (WEINBERGER;SOFUOGLU, 2009). Assim parece haver uma relação de complementaridade entre o uso de tabaco e as outras substâncias psicoativas, o fato é que nessa pesquisa ele aparece sendo utilizado por usuários de crack, antes e durante o tratamento (neste caso para diminuir a fissura).

O uso do álcool e da maconha apareceu com o mesmo grau de relevância no presente estudo. A maconha foi citada como "calmante" pelos entrevistados, fato que também está presente em outra pesquisa, como uma substância que reduz a fissura (OLIVEIRA, 2011). Estudo também relata que usuários de crack fazem mais uso de maconha do que usuários de outras drogas (MOURA et al, 2014).

Com o uso de outras SPA o abuso do álcool é tido como primário, ocorrendo antes do inicio do uso de drogas ilícitas com diminuição do consumo com o inicio do uso da substância ilícita, já com a cocaína ocorre o contrário, a dependência do álcool é secundária, pois ocorre depois do inicio da dependência da cocaína, como forma de atenuar os efeitos negativos do crack/cocaína e estimular o efeito de euforia. Assim o álcool precipita a recaída (MARLATT; WITKIEWITZ, 2009; GOMES, 2007)

Em relação à autoeficácia, ou seja, a confiança que o indivíduo tem em lidar com um acontecimento (MARLLAT; WITKIEWITZ, 2009), no caso o controle do uso, quando 
questionados, os participantes citaram as dificuldades em se manterem abstinentes ou controlados, sendo que a fissura é vista como a maior dificuldade.

Para Balbinot et al(2011) quanto mais recente o último uso maior a fissura, já outro autor Minozzi et al (2008), refere que quanto maior o tempo de abstinência maior a fissura, assim não se tem um consenso sobre o tema, o que se sabe é que a fissura está atrelada a autoeficácia e também às expectativas em relação ao uso (ARAUJO et al, 2011c; KESSLER et al, 2010). Dois participantes chegaram a relatar a vontade de fazer o uso da droga como algo orgânico, que se "encontra no sangue", estudos demonstram que usuários de SPA têm alterações cerebrais de longa duração ou até mesmo irreversíveis, dificultando o controle ou a abstinência (WEISS et al, 2003). Tal dado não foi possível de identificar no presente estudo.

A falta de apoio social foi percebida na pesquisa como uma dificuldade para o processo de controle, já que usuários de drogas, principalmente de crack são resistentes à mudança de comportamento e se sentem desmotivados, ter o apoio de terceiros seria essencial para a continuidade do processo (CATILLO, 1986). Familiares e sociedade em geral possuem preconceito com usuários, principalmente usuários de crack, desacreditando na possibilidade de recuperação desses (PAULA et al, 2014).

O desconhecimento do problema também apareceu na fala de um participante, a desinformação ou até mesmo não reconhecer e aceitar os danos decorrentes do uso dificulta o processo de controle, o que corrobora com resultados de outras pesquisas (GABATZ et al, 2013; MCKAY et al, 2013; SELEGHIM; OLIVEIRA,2013).

Os sintomas psiquiátricos, a exemplo dos apresentados por um dos participantes pode ser um motivo de uso de SPA. Sendo que as desordens mentais geralmente precedem o aumento do uso em usuários de drogas (SCHEFFER; PASSA; ALMEIDA, 2010). O paciente do presente estudo ligava o uso de SPA à crença de que ele era "fraco do espírito", essa visão determinista e imposta apresenta semelhanças com o já relatado "erro de caráter" (PEDROSO; KESSLER; PECHANSKY, 2013; RAUPP; MILNITISKY-SAPIRO, 2008).e

Estima que 35,8\% dos usuários de SPA apresentem comorbidades psiquiátricas (WITKEWITZ et al,2013,) e 23,52\% dos usuários de drogas utilizam psicotrópicos (SCHEFFER; PASA, ALMEIDA, 2010). As comorbidades estão interligadas a piores prognósticos, e as drogas podem ser usadas para aplacar os sintomas da comorbidade ou para dar uma explicação ao fato, por isso trata-las é fundamental para que o indivíduo possa se 
concentrar apenas na problemática da dependência (ALVES; RIBEIRO, 2010; SCHEFFER; PASSAS; ALMEIDA, 2010).

Ainda sobre o autocontrole, cinco entrevistados falaram sobre as expectativas em relação ao controle do uso, sendo que todos mencionaram planos futuros, o ter um "objetivo de vida" e autoconfiança na mudança de comportamento como motivadores para a manutenção da abstinência. A autoestima aparece em estudos associada a resultados positivos de controle do uso, pois segundo pesquisa ter um objetivo de vida e autoconfiança ajudam no controle (RIGOTTO; GOMES, 2002).

O medo da volta ao uso existia nos participantes (5) o que também está presente em estudos sobre a temática, os indivíduos que fazem uso de SPA têm muitas incertezas e medos quando se questionam se serão capazes de transpor as barreiras do uso (BUCHELE; MARATI; RABELO, 2004). A sensação de que não serão capazes os leva a um sentimento de fracasso, gerando sentimentos negativos que levam o usuário a uma recaída, além do que pessoas com pouca autoconfiança têm piores prognósticos (MCKAY et al, 2013).

A recaída foi citada pelos participantes como algo recorrente, que muitas vezes ocorre além da força de vontade do indivíduo. Para dois participantes, os períodos de reclusão em comunidades terapêuticas foram momentos de abstinência, mas logo após a saída desses locais ocorreu a recaída, fato corroborado por estudo que relata que após longos períodos de reclusão, a recaída é fator predominante (PEDROSO; KESSLER; PECHANSKY, 2013). Ainda sobre as comunidades terapêuticas, estudo aponta que ao sair da comunidade o indivíduo não tem recursos para tentar outras opções de vida a não ser voltar para o uso de crack ou tornarem-se monitores das próprias comunidades, já que essas não os empoderam ou dão oportunidades de mudança efetivas de vida, além do que o projeto desses locais visa na maioria dos casos, a tentativa de moralização do paciente (RAUPP; MILNITISKY-SAPIRO, 2008).

A Recaída pode ser interpretada pelo indivíduo como um momento de aprendizagem e de mudança comportamental, se esse indivíduo estiver com prontidão para a mudança e autoeficácia (FRANÇA; SIQUEIRA, 2011). A recaída percebida como algo sobrenatural também foi citada, reforçando a necessidade de se tratar as comorbidades psiquiátricas.

A duração do tempo de abstinência foi relata pelos participantes, sendo que o tempo variou de um a dez meses sem o uso da droga. Estudo demonstra que a tentativa de se manter 
longe das drogas gera instabilidade no usuário (RIGOTTO; GOMES, 2002), sendo por isso primordial todo o apoio e auxilio a esse indivíduo, para se afastar dos estímulos ambientais e sociais, além de estimular a mudança no círculo de amizades (LE MOAl, 2006; PAULA et al, 2014).

Enfim para se alcançar a abstinência é necessário um conjunto de artefatos para o enfrentamento da problemática, além do apoio social e especializado (seja ele em um CAPS ad, grupo de autoajuda ou igreja), o reconhecimento do problema e a vontade para superar as barreiras. Não se tem como trabalhar ou apontar apenas um fator para o uso ou não das drogas, tanto os determinantes intra quanto interpessoais devem ser trabalhos em conjunto com o paciente para que esse consiga o controle do uso de SPA, a abstinência e a prevenção da recaída.

As estratégias de enfrentamento englobam os artifícios utilizados pelo indivíduo para superar situações tidas como de alto risco (MARLATT; WITKIEWITZ, 2009). Nesse estudo, a estratégia mais relatada foi a de buscar uma ocupação, "ocupar a mente" para não se lembrar da droga, já que a abstinência provoca uma sensação de vazio relacionado à falta de ocupação e de esperança no futuro (SABINO; CAZENAVE, 2005). Manter as obrigações sociais é uma estratégia que ajuda no processo de não uso da substância ou uso controlado (DECORTE, 2001; RIGOTTO; GOMES, 2002; RODRIGUES et al, 2012).

A segunda estratégia mais utilizada foi a motivação, “o querer parar”, neste estudo os participantes relataram que seria necessário "querer parar", que a interferência de outras pessoas não influência se o indivíduo não desejar realmente parar. Fato corroborado em outro trabalho em que a motivação foi considerada essencial, sem a qual o indivíduo não está apto à mudança de comportamento (FRANÇA; SIQUEIRA, 2011). O indivíduo passa por vários estágios de prontidão para a mudança, e quando ele alcança a fase da ação é o momento em que realmente tem forças para o não uso de SPA (MCKAY et al, 2013), portanto é quando necessita de maior apoio.

Com a mesma relevância destacaram-se cinco estratégias: frequentar o grupo, o uso de outra substância, apego a crença religiosa, uso de medicação e ficar em casa. O frequentar o grupo refere-se à presença em grupos de autoajuda (1 partic.) como os narcóticos anônimos, sendo considerado uma boa estratégia de enfrentamento, pois nesses locais eles encontram pessoas que já passaram por todo o processo e podem ajuda-los na superação. A busca por 
grupos de autoajuda é relatada pela literatura como importante fonte de socialização e meio para se sentir útil e pertencente a um grupo, o indivíduo passa a ter uma identidade social (MCKAY et al, 2013; RIGOTTO; GOMES,2002).

Havia a expectativa de que o CAPS ad (citado apenas por dois participantes) fosse mais utilizado como meio de enfrentamento e visto como um local estratégico para os que o frequentam, o que não ocorreu e não há elementos que indiquem as possíveis razões, talvez exista a questão do estigma social, por ser um serviço especializado em álcool e drogas, com grande visibilidade perante a sociedade (HORTA et al, 2011). Estudo também aponta a falta de interesse do usuário de drogas em frequentar o CAPS ad, vinculada à maneira como o serviço é organizado, sendo muitas vezes rígidos e sem perspectivas de mudança do papel social do individuo ou reconstrução de laços de solidariedade (PINHO et al, 2012).O frequentar o CAPS ad apresentou menos relevância do que o uso de outras substâncias, sendo que a maconha foi a única citada, utilizada como calmante, esta substância também foi mencionada com o mesmo propósito em estudo que destaca o uso não apenas da maconha, mas do álcool como estratégias utilizadas pelos usuários de crack (OLIVEIRA; NAPPO,2008).

Frequentar um grupo religioso, "ter fé" em algo, também foi visto como facilitador no processo de não uso de substâncias psicoativas, destaca-se que esses grupos religiosos têm um papel semelhante a dos de autoajuda, auxiliando com conselhos, exemplos de pessoas que já passaram pelo mesmo "problema" e até mesmo ajudando os usuários a conseguir um emprego. Outros estudos corroboram esse item ao citarem a religião como uma estratégia de enfrentamento (RIGOTO; GOMES, 2002; PEDROSO; KESSLER; PECHANSKY, 2013). A religião aproxima-se de uma oferta/ resposta ao associar o uso de SPA ao distanciamento de Deus, assim quanto o indivíduo se volta à crença religiosa ele passa a pertencer a uma nova comunidade e se reencontra com Deus (RAUPP; MILNITISKY-SAPIRO 2008).

A utilização da medicação também foi relatada (três participantes), sendo percebida como importante auxiliar no tratamento, já que ajuda a passar a fissura e interfere na vontade do indivíduo de sair de casa para buscar a droga, o uso de calmantes (benzodiazepínicos) por parte dos usuários de drogas foi relatado por estudo como estratégia para adormecer. Analisando o uso de SPA do ponto de vista apenas biológico, a medicação entraria com o objetivo de redução do desejo, inibição do comportamento de busca pela droga, já que alivia os sintomas de abstinência (KAMPMAN, 2010) 
O "ficar em casa", ou seja, evitar ter contato social, também foi mencionado (três participantes), podendo ser visto como benéfico por ajudar o indivíduo a não fazer o uso, mas limita seu espaço social e diminui a sua rede de apoio, que é importante para o usuário se sentir útil e fazer parte de um grupo (RIGOTTO; GOMES, 2002; MCKAY et al, 2013).

Desviar dos pontos de venda da SPA e de amigos de uso também apareceu como estratégia nesta pesquisa ( 2 participantes). A retirada do sujeito do meio social e físico que pode fazê-lo se lembrar do uso ou até mesmo leva-lo a consumir a SPA é fundamental para o processo de recuperação (SABINO; CAZENAVE, 2005; RIGOTTO; GOMES, 2002). O afastamento das pessoas que eram companheiros de uso ou que sabem onde encontrar a substância também é imprescindível por dificultar o acesso à droga (DECORTES, 2001; PEDROSO; KESSLER; PECHANSKY, 2011; RIGOTTO; GOMES, 2002; PAULA et al, 2014)

Durante a segunda entrevista percebeu-se entre os participantes (seis) que continuaram o tratamento, existir em alguns (4 partic.) a tentativa de manter o prazer proporcionado pelo uso de drogas. Essa tentativa de manutenção apareceu em ações como a interrupção do uso da medicação para se ter uma noção de "normalidade" e desafio as regras, além do uso de outras substâncias como substitutivas ao crack, sendo o álcool a principal. Houve a menção de vivência dos efeitos da droga através de sonhos e lembranças.

Tanto na primeira quanto na segunda entrevista os participantes demonstraram em sua maioria (13 participantes) uma visão de otimismo ou de normalidade sobre suas mudanças de comportamento. Estudos relatam que pessoas com a autoestima baixa e ausência de autopercepção são propensas a continuar a usar SPA (CARVALHO et al, 2011; RIGOTTO; GOMES, 2002), já no presente estudo os quatro que possuíam uma visão negativa sobre si continuaram o tratamento. Dois mudaram sua autopercepção de negativa para positiva e dois continuaram com visões negativas, mas com redução do uso de SPA e com seguimento no tratamento. Outro autor relata que pessoas que possuem autocrítica exacerbada são mais propensas a uma recaída (ARAUJO et al, 2011c), situação que pode ter ocorrido com alguns participantes que acreditavam que mesmo com a melhora ainda tinham um grande percurso para percorrer.

Quanto à percepção dos outros, seis relataram na primeira entrevista não se importar com a opinião alheia, o que pode ser associado a comportamento antissocial (GABATZ et al,2013), pesquisa relata que em média 53,3\% dos usuários de SPA possuem 
transtorno de personalidade antissocial (SCHEFFER; PASA; ALMEIDA, 2010). Quando o uso da SPA passa a ser prioridade a pessoa pode manifestar esse comportamento, pois o que realmente importa são o uso e obtenção da SPA (ARAUJO et al, 2011c). Familiares chegam a relatar que os usuários não possuem afetos a não ser pelas drogas (PAULA et al, 2014), o que pode estar ligado ao embotamento social que ocorre com os usuários (NONTICURI, 2010). Também pode-se inferir que esse comportamento seja uma forma de defesa, pois seus vínculos com outros podem ser precários ou inexistentes.

Tal afirmação tem suporte quando se refere ao bom relacionamento com outras pessoas, fator importante para a recuperação da autoestima e abandono do comportamento antissocial. No estudo cinco participantes, durante a primeira entrevista relataram perceber algum tipo de preconceito por parte dos outros, o que não estimula a mudança de comportamento, já que o meio social pode não ser acolhedor. A frustração por não alcançar a aprovação social pode levar a recaída (RIGOTO; GOMES, 2002). Apenas dois participantes mencionaram considerar a opinião de outras pessoas, mas de forma seletiva (só a opinião de algumas pessoas). Na segunda entrevista, quatro responderam ao questionamento, sendo que houve melhora da percepção para dois entrevistados que na primeira entrevista não valorizavam a opinião de terceiros e passaram a considera-la após três meses.

A percepção quanto às fontes de apoio foi dividida entre apoio dado pela família e por outros, como vizinhos e entidades religiosas, além do questionamento sobre a percepção da amizade. Quanto à família percebeu-se que todos os participantes citaram mais de um membro, ora como fonte de apoio ora como apoio insuficiente. O membro tido como o que ofertou maior apoio foi à figura materna (quatro participantes). A esse respeito estudo mostra que jovens que buscam respeitar os sentimentos maternos tem menor propensão a procurar o uso de drogas (SILVA et al, 2007). Quando ocorre o uso, outro estudo evidencia a mãe como responsável pela procura de ajuda e apoio durante o tratamento (COSTA et al, 2011; DIAZ et al, 2009; SELEGHIM; OLIVEIRA,2013).

Também, resultados de pesquisa sugerem haver em indivíduos que mantém o vínculo familiar forte no momento da internação um maior rendimento durante o mesmo (CARVALHO et al, 2011) e após alta um menor padrão de uso (SELEGHIM; OLIVEIRA. 2013). 
Os outros membros citados como principais fontes de apoio foram os filhos (2 participantes) e irmãos (2 participantes), não foi encontrado estudos que relatam especificamente, sobre o apoio desses membros familiares. Fato interessante foi a figura paterna não aparecer nas falas dos entrevistados como fonte de apoio, mas sim como fonte insuficiente de ajuda (6 participantes), tem-se o relato que em famílias de usuários, geralmente existe a ausência de um dos progenitores (COSTA et al, 2011; SELEGHIM; OLIVEIRA, 2013). Para quatro entrevistados na presente pesquisa houve a ausência da figura paterna.

A cobrança excessiva por parte de parentes também apareceu nas falas, sendo que a pressão pode ser considerada fator de risco. Famílias muito rígidas, em que se tem muita cobrança são consideradas como fator de risco para o uso (SELEGHIM; OLIVEIRA, 2013).

Domingos (2012), em seu estudo menciona a necessidade dos familiares compreenderem o uso da droga, mas na verdade estes se sentem traídos pelo usuário, o que cria uma pressão maior para o indivíduo. A família se torna codependente e adoece juntamente com o usuário, sendo essencial o tratamento de seus membros também, pois ela se perde em uma ambiguidade entre a proteção ilusória e a negação do uso, atitudes que dificultam o auxílio eficaz (RIGOTTO; GOMES, 2002; PAULA et al, 2014).

Estudos demonstram que o uso se inicia geralmente em casa, vendo um parente fazer o uso e o imitando, principalmente irmãos (FACUNDO et al, 2011; PINHO et al, 2012; HORTA et al, 2014; SCHEFFER; PASA; ALMEIDA, 2010). Essas famílias possuem perfis de terem regras muito rígidas ou muito permissivas, sem regras bem estabelecidas e falta de autoridade (SELEGHIM; OLIVEIRA, 2013; YOUNG; WEST, 2010), além de serem habitualmente ambientes conflituosos, muitas vezes violentos, com relatos de maus tratos/ abandono e de histórico de uso de drogas (HORTA et al, 2014; PINHO et al, 2012), além de falta de diálogo entre os membros nas famílias (MCKAY et al, 2013; GABATZ et al, 2013; COSTA et al, 2011). Isso também aparece no presente estudo com a menção pelos participantes, de famílias disfuncionais, pais usuários e de histórico de conflitos tanto conjugais quanto familiares.

Outras fontes de apoio citadas foram os vizinhos, grupos de autoajuda e CAPS ad. Todas as fontes de apoio são positivas para a manutenção da abstinência ou na continuidade do tratamento (MARLLAT; WITKIEWITZ, 2009). A convivência com indivíduos 
recuperados ou em processo de recuperação é visto como benéfico para o usuário de drogas (RIGOTTO; GOMES, 2002), assim frequentar grupos de autoajuda e os espaços de tratamento disponíveis (CAPS ad) podem ser visto como importantes.

A percepção sobre a amizade é importante já que esse grupo faz pressão direta no usuário de droga (BUCHELE; MARATI; RABELO, 2004). Para os entrevistados (7 participantes) a amizade não existe, sendo que a maioria deles evitavam um convívio mais estreito com outras pessoas, o que reforça a ligação entre o uso da droga e o comportamento antissocial, para quem a SPA passa a ser prioridade (GUIMARÃES et al, 2008; SCHEFFER, PASA, ALMEIDA, 2010). Os participantes também relataram a perda de amizades de antes do uso de drogas, mas a atribuíram a si mesmo, o que corrobora com o isolamento social proporcionado pelo uso, sendo a substância um "prazer solitário" para o usuário (RIGOTTO; GOMES, 2002). 


\section{CONCLUSÃO}

Os resultados apresentados permitem afirmar que em relação ao perfil dos usuários de crack tratados pelo CAPS ad, os dados sociodemográficos concordaram com a literatura nacional; exceto no que tange a média de idade.

O grupo estudado revelou ter iniciado o consumo de drogas com o uso das licitas na adolescência e uma percepção já como adultos que as mesmas não eram prejudiciais a saúde, apenas o crack foi visto como uma "droga". Cabe resaltar que ao contrário do senso comum a obtenção da droga não foi através de furtos ou violência, pois nenhum participante relatou obter o crack através de atos ditos ilegais, mas à custa de dinheiro do trabalho ou venda/ penhora de bens pessoais ou capturados da família.

Verificou-se que as busca de tratamento institucional (CAPS) pelas mulheres usuárias é incipiente e observou-se em relação a elas a presença de um preconceito maior e estigma. Apareceu também a troca de sexo por dinheiro ou crack, o que as torna um grupo mais vulnerável.

Constatou-se que a busca do tratamento ocorria quando o usuário percebia que não possuía mais controle sobre o uso, mas manter-se vinculado a esse tratamento mostrou-se ser uma tarefa difícil e para alguns não teve continuidade, pois poucos (apenas seis) se mantiveram em tratamento após três meses da abordagem inicial.

A relação dos usuários de crack com as demais SPA (lícitas e ilícitas) mostrou-se ambivalente, pois foram percebidas como benéficas ao controle de uso (maconha, álcool e tabaco), particularmente o álcool, percebido também como gatilho ou porta de entrada para o uso. Um verdadeiro ciclo vicioso; usam o álcool para aliviar a fissura por crack e o uso dele remete ao uso de crack.

Sobre os determinantes intrapessoais, a autopercepção pareceu não ser fator importante para a recaída nesse estudo, já que mesmo participantes com percepções negativas se si mesmos continuaram o tratamento, enquanto outros com visões otimistas recaíram ou abandonaram o tratamento. Entretanto, pode-se inferir que os primeiros talvez por terem uma autoimagem negativa real de si mesmos, sentiram maior necessidade de reforço e apoio. Já os outros que mostraram uma percepção otimista de si, talvez em bases não muito realistas, o que os levou a superestimar as suas forças e capacidades de enfrentamento. Esse resultado mostrou uma limitação do estudo, e um foco a ser abordado em uma próxima pesquisa. 
Quanto à importância que se atribuiu a opinião dos outros se percebeu que houve uma mudança nos participantes que continuaram o tratamento, do primeiro ao último encontro, quando passaram a considerar a opinião alheia, mesmo que de forma seletiva.

As expectativas iniciais de uso, pareceram relacionadas ao não saber lidar ou não suportar eventos negativos em suas vidas, a droga então surgia como um refúgio ou uma tentativa de autoextermínio. A curiosidade, ou até mesmo sentimento de onipotência, de pensar que poderiam apenas experimentar e "voltar para suas vidas" novamente. Também apareceu a visão determinista, de que o uso de drogas é algo próprio do indivíduo, um desvio de caráter.

Tais expectativas dos usuários se fundem com os motivos para o uso e sua manutenção. Como não conseguem lidar com acontecimentos negativos, os sentimentos negativos como raiva, ansiedade, sensação de fracasso e vazio, os levam ao uso. O mesmo ocorre face às situações de estresse e frustração como, brigas familiares e conjugais. Como motivação para o uso, os momentos de lazer e o convívio com amigos de uso, também apareceram relevantes. Portanto, as expectativas dos usuários em relação ao papel que atribuem as drogas e as motivações para o uso, são determinantes intrapessoais que devem ser considerados pelos profissionais de saúde e de enfermagem, no concernente ao tratamento. Assim como possíveis manifestações de transtornos psiquiátricos, pois substâncias psicoativas (licitas e ilícitas) podem estar sendo utilizadas para minimizar os sintomas.

As formas de enfrentamento da dependência e manutenção da abstinência referidas neste estudo dizem respeito a tentativas de ocupar "a mente" com outros afazeres, e o sentirse motivado para interromper o uso. Cabe destacar que o serviço especializado (CAPS ad) teve um papel pouco relevante como estratégia de enfrentamento, cabe uma reflexão mais profunda sobre esse resultado, pois outros espaços "terapêuticos" (AA, grupos religiosos) foram percebidos como positivos.

O uso de medicação e o isolamento social também apareceram como formas de enfrentamento, pois a medicação faz com que o usuário não tenha animo para sair de casa na busca de pontos de venda e encontro com amigos de uso. Ambas, limitam a vida plena do individuo ao cercear o seu convívio social.

Os participantes citaram os fatores interpessoais e caracterizaram as fontes de apoio, sendo a família a maior fonte de apoio, embora alguns tenham relatado conflitos e brigas, além de cobrança excessiva como geradores de sentimentos negativos que induziam ao uso. 
Destacou-se a figura materna como a principal fonte de apoio, e a paterna a mais ausente. $\mathrm{O}$ que aparece em outros estudos sobre o tema.

A fissura apareceu entre os participantes deste estudo como o maior dificuldade para a manutenção da abstinência, portanto um determinante intrapessoal percebido como algo orgânico e de urgência. Vinculado a autoeficácia para enfrentar sentimentos negativos e situações estressoras e também a autoestima, pois o usuário precisava sentir-se capaz do autocontrole.

Entretanto, o controle ou superação da fissura é também determinado por fatores interpessoais, segundo os participantes, na medida em que nos seus relatos, quanto maior e melhor o apoio social recebido, mais se sentiam fortalecidos.

A recaída foi percebida como ocasionada por determinantes intrapessoais e interpessoais, sendo algo recorrente do usuário, percebida como fator que vai além das forças. Os usuários que continuaram o tratamento relataram diminuição do uso de crack e e até mesmo a abstinência.

Pode-se assim dizer que o uso do crack e suas recaídas estão atrelados aos fatores intrapessoais e interpessoais, sendo que eles se retroalimentam, criando um círculo vicioso, quem que os fatores inerentes ao indivíduo se refletem em seu meio social e rede de apoio e esses afetam de maneira direta os fatores intrapessoais, não tendo como desassocia-los.

No atendimento ao usuário de crack ou outras substâncias psicoativas, não se deve trabalhar apenas uma faceta do uso ou do motivo da recaída, mas sim reconhecer juntamente com o usuário, quais os gatilhos de recaída, qual é a rede de apoio desse indivíduo e o quais suas expectativas futuras de vida, para assim traçarem objetivos e mecanismos de defesa factíveis para se conseguir manter o uso controlado ou a abstinência. Ressaltando que a recaída é algo esperado e deve ser visto pelo profissional de saúde como apenas mais uma das etapas de recuperação do indivíduo. 


\section{REFERÊNCIAS BIBLIOGRÁFICA}

ABDALLA, R.R. et al.Prevalence of cocaine use in Brazil: Data from the II Brazilian National alcohol and drugs survey(BNADS). Addictive behaviors, vol. 39, n. p,.297-301, 2014.

ALVES, H.N. P; RIBEIRO, M. Tratamento medicamentoso. IN: RIBEIRO, M; LARANJEIRA, R. Tratamento do usuário de crack: Avaliação Clínica, psicossocial, neurológica e de risco. Terapias psicológicas, farmacoterapia e reabilitação. Ambientes de tratamento. São Paulo: Editora casa leitura Medica 2010. p. 267-278.

ARAÚJO, R.B et al. As estratégias de coping para o manejo da fissura de dependentes de crack. Rev HCPA, v. 30, n. 1, p. 36-42, 2010 b.

ARAÚJO, R.B et al. Tratamento de exposição a estímulos e treinamento de habilidades como coadjuvantes no manejo do craving em um dependente de crack. Trends Psychiatry Psychother, v. 33, n. 3, p. $181-188,2011$.

ARAUJO, R.B; PEDROSO, R. S; CASTRO, M.G.T. Adaptacao transcultural para o idioma portugues do Cocaine Craving Questionnaire - Brief. Rev Psiq Clín. V. 37, n. 5, p.195- 198, 2010a.

ARAUJO, R.B et al Avaliação do craving em alcoolistas na síndrome de abstinência. PsicoUSF.Vol. 9, n 1, p. 71-76, 2004.

Associação Americana de Psiquiatria. DSM-IV: manual diagnóstico e estatístico de transtornos mentais. 4a ed. rev. Porto Alegre: Artmed; 2002.

BACA, C. T; YAHNE, C. E. Smoking cessation during substance abuse treatment: What you need to know. Journal of Substance Abuse Treatment. Vol.36, n.2, p 205-219, 2009.

BAGØIEN, G.et al. The effects of motivational interviewing on patients with comorbid substance use admitted to a psychiatric emergency unit - a randomized controlled trial with two year follow-up. BMC Psychiatry, v.93, n.13. 2013.

BAKER, T., MORSE, E., SHERMAN, J. The motivation to use drugs: A psychobiological analysis of urges. In: RIVERS, C. Alcohol use and abuse: Lincoln: University of Nebraska Press 1987. pp. 257-323.

BALBINOT, A.D et al. Associação entre fissura e perfil antropométrico em dependentes de crack. J Bras Psiquiatr.Vol. 60, n.3, p 205-209, 2011.

BARDIN, Laurence. Análise de Conteúdo. 4ª Edição. Lisboa: Edições 70, 2009.

BEEDER, A. B.; MILLMAN, R. B. Patients with psychopatology. In: LOWINSON, J. H. et al. Substance abuse: a comprehensive textbook. 3rd ed. Baltimore: Williams \& Wilkins, 1997. p. 551-562. 
BEVAN, G.E.Z. Problem drug use the public health imperative: what some of the literature says. Substance Abuse Treatment, Prevention, and Policy, v.4, n. 21. 2009.

BISCH, N.K et al. Aconselhamento telefônico para jovens usuários de crack. Rev. Gaúcha Enferm.(Online), v.32, n.1,p. 31-39, $2011 . \quad$ Disponível em: http://www.scielo.br/scielo.php?script=sci_arttext\&pid=S198314472011000100004\&lng=en\&nrm=iso. Acesso em 2 de outubro de 2014.

BOWEN, S. et al. Mindfulness-based relapse prevention for substance use disorders: A pilot efficacy trial. Substance Abuse, vol.30, n.4, p. 295-305, 2009.

BRASIL, Plano nacional. Crack é possível vencer! Brasília, DF, 2011. Disponível em: < http://www.brasil.gov.br/crackepossivelvencer/home > acesso em: 19 de Março de 2013.

BRASIL. Ministério da Educação. Secretaria de Educação Fundamental (BR). Parâmetros Curriculares Nacionais. Brasília; 1997.

BRASIL. Secretaria Nacional de Políticas sobre Drogas. Relatório brasileiro sobre drogas. Brasília: SENAD, 2009

BRUEHL, M.A. et al. Craving and control: methamphetamine users' narratives. J Psychoactive Drugs. Suppl. 03, p. 385-392, 2006.

BUCHELE, F; MARATI, M; RABELO, D.R. Dependência química e prevenção a recaída. Texto e contexto enferm. Vol. 13, n. 2, p 233-240, 2004.

CAREY, KATE B.Understanding binge drinking: Introduction to the special issue. Psychology of Addictive Behaviors, Vol 15, n.4, p 283-286, 2001.

CARLSON, R.G. et al. Predictors of substance abuse treatment entry among rural illicit stimulant users in Ohio, Arkansas, and Kentucky. Subst. abus, v. 31, n. 1, p. 1-7, 2010.

CARROLL, K.M; BALL, S.A. Avaliação de abuso e dependência de cocaína. In: DONOVAN, D.M; MARLATT, G.A. Avaliação dos comportamentos dependentes. São Paulo: Editora Roca, 2010, p. 157-184.

CARROLL, K.M; RAWSON, R.A. Dependência de psicoestimulantes. IN: MARLATT, G.A; DONOVAN, D. M. Prevenção de recaída. São Paulo: Artmed, 2009.

CARVALHO, F.R.M et al. Causas de recaída e de busca por tratamento referidas por dependentes químicos em uma unidade de reabilitação. Colombia Médica, v.42, n.2, p. 57$62,2011$.

CASTILLO, P. P. Ethical aspects of drug evaluation in human beings. Rev Clin Esp. vol. 179, n. 1, p. 42- 9, 1986.

CHAVES, T.V et al. Fissura por crack: comportamentos e estratégias de controle de usuários e ex- usuários. Rev Saúde Pública, v.45, n.6, p.1168-75, 2011. 
COSTA, B.T et al. Funcionamento Transgeracional de Famílias de Usuários de Crack. Psicologia Argumento. v. 32, n. 76, 2014.

CRESWELL, J.W. Research design: qualitative, quantitative and mixed methods approaches. $3^{a}$ edição, Thousand Oaks: Sage Publications; 2009.

CRESWELL, J.W. Research design: Quantitative, qualitative and mixed methods approaches. $4^{a}$ edição, Californnia: Sage Publications, 2014.

DALGALARRONDO, P. et al . Religião e uso de drogas por adolescentes. Rev. Bras. Psiquiatr., v. 26, n. 2, p.82-90 2004. Disponível em: http://www.scielo.br/scielo.php?script=sci_arttext\&pid=S1516-

44462004000200004\&lng=en\&nrm=iso. Acesso em: 20 de outubro. 2014.

DECORTE, TOM. Drug users' perceptions of 'controlled' and 'uncontrolled' use. International Journal of Drug Policy, vol.12, p. 297-320, 2001.

DEL PRETTE, A; DEL PRETTE, Z.A.P. Habilidades sociais: conceitos e campo teóricoprático. São Carlos, UFSCAR; 2006. Disponível em: < http://www.rihs.ufscar.br/armazenagem/pdf/artigos/habilidades-sociais-conceitos-ecampo-teorico-praticor> acesso em: 24 de Setembro de 2012.

DIAZ, C.J.B et al . El consumo de drogas y su tratamiento desde la perspectiva de familiares y amigos de consumidores: Guatemala. Rev. Latino-Am. Enfermagem, , v. 17, n. spe,p.824-30, $2009 \quad$ Disponível em: http://www.scielo.br/scielo.php?script=sci arttext\&pid=S010411692009000700011\&lng=en\&nrm=iso. Acesso em: 20 de outubro de 2014.

DINI, G.M; QUARESMA, M.R; FERREIRA, L.M. Adaptação cultural e validação da versão Brasileira da escala de auto estima de Rosenberng. Rev. Soc. Bras. Cir. Plast, v.19, n.1, p. 41-52, 2004.

DOMINGOS, J. B.C. Fatores associados ao uso de cocaína e/ou crack em clientes de um CAPS ad. 2012. P. 167. Tese (doutorado)- Universidade de São Paulo Escola de enfermagem de Ribeirão Preto, São Paulo; 2012.

DUAILIBI, L.B; RIBEIRO, M; LARANJEIRA, R. Profile of cocaine and crack users in Brazil. Cad. Saúde pública, v.44, n 4, p. 545-57. 2008.

DUFFY, P.; BALDWIN,H. Recovery post treatment: plans, barriers and motivators. Substance Abuse Treatment, Prevention, and Policy, v.6, n 8, p. 1-12, 2013.

EDLUND, M.J et al. Religiosity and decreased risk of substance use disorders: is the effect mediated by social support or mental health status? Soc Psychiatry Psychiatr Epidemiol. v.45,n.8, p.827-36. 2010.

EPSTEIN, D.H et al. Tobacco, cocaine, and heroin: Craving and use during daily life. Addictive Behaviors, v. 35, n. 4 p. 318-24, 2010. 
FACUNDO, F.RG et al. El consumo de drogas como una práctica cultural dentro de las pandillas. Rev. Latino-Am. Enfermagem. v. 19, n. spe, p. 839-47, 2011.

FALCK, R..S et al. The prevalence of psychiatric disorder among commutiy sample of crack cocaine user: an exploratory study with pratical implications. J. Nerv. Ment. Dis., v.199, n. 7, p. 503-07. 2004.

FERREIRA FILHO, O.F et al. Perfil sociodemográfico e de padrões de uso entre dependentes de cocaína hospitalizados. Rev Saúde Pública, v. 37, n. 6, p. 751-59, 2003.

FILHO, O.F.F. et al. Perfil sociodemográfico e de padrões de uso entre dependentes de cocaína hospitalizados. Rev Saúde Pública, v. 37, n. 6, p 751-9,2003.

FOCCHI, G.R.de A.; LEITE, M.C; SCIVOLETTO, S. Utilização do agonista dopaminérgico pergolida no tratamento da "fissura" por cocaína. Rev Bras Psiquiatr, vol. 23, n. 4, p. 18894, 2001.

FRANÇA, M.G; SIQUEIRA, M.M. O papel da enfermagem e a formação de multiplicadores ante o processo de prevenção à recaída. SMAD, Rev. Eletrônica Saúde Mental Álcool Drog. V. 7, n. 2, p. 78- 84,2011. Disponível em: https://docs.google.com/viewer?url=http://www.redalyc.org/pdf/803/80323608005.pdf\&chro $\underline{\text { me}=\text { true }}$. Acesso em: 18 de Março de 2013.

FRIEDRICH, M.A. O consultório na rua enquanto estratégia inovadora para o cuidado aos usuários de drogas. 2012.69f. (Trabalho de conclusão de curso de enfermagem)- escola de enfermagem Universidade Federal do Rio Grande do Sul, Rio Grande do Sul.

GABATZ, R.I.B et al. Percepção dos usuários de crack em relação ao uso e tratamento. Rev Gaúcha Enferm. Vol. 34, n. 1, p. 140-46, 2013.

GIBBS, G.R. Qualitative Data Analysis: Explorations with NVivo. New York: Open University Press. 2007.

GOMES, F.C et al . Religion as a protective factor against drug use among brazilian university students: a national survey. Rev. Bras. Psiquiatr., v. 35, n. 1,p.29-37, 2013 .

Disponível em: $\quad$ http://www.scielo.br/scielo.php?script=sci arttext\&pid=S151644462013000100006\&lng=en\&nrm=iso. Acesso em: 20 Outubro de 2014.

GOMES, L.S. Organizações de serviços para tratamento de usuários e dependentes de cocaína e crack IN: CORDEIRO, D.C; FIGLIE, N.B; LARANJEIRA, R. Boas práticas no tratamento do uso e dependência de substâncias. São Paulo: ROCA, 2007. p.74-9.

GUINDALINI, C. Concurrent crack and powder cocaine users from Sao Paulo: do they represent a different group? BMC Public Health. Vol. 10, n. 6, 2006.

HATSUKAMI, D.K; FISCHMAN, M.W. Crack cocaine and cocaine hydrochloride. Are the differences myth or reality? Jama. V. 276, n 19, p. 1580-8, 1996

HENDERSHOT, C.S.H. Relapse prevention for addictive behaviors. Substance Abuse Treatment, Prevention, and Policy, v.15, n.6, p 1-17, 2011. 
HORTA, R.L et al . Perfil dos usuários de crack que buscam atendimento em Centros de Atenção Psicossocial. Cad. Saúde Pública,v. 27, n. 11, Nov. 2011 . Disponível em: http://www.scielo.br/scielo.php?script=sci_arttext\&pid=S0102-

311X2011001100019\&lng=en\&nrm=iso. acesso em: 08 de Outubro de 2014.

HORTA, R.L et al. Influência da família no consumo de crack. J. Bras. Psiquiatria, v. 63, n.2, p. 104-12, 2014.

HSU, S.H; COLLINS, S.E; MARLATT, A. Examining psychometric properties of distress tolerance and its moderation of mindfulness-based relapse prevention effects on alcohol and other drug use outcomes. Addictive Behaviors, v.38, n. 3, p.1852-8 2013.

II Levantamento Nacional de Álcool e Drogas (LENAD) - 2012. Ronaldo Laranjeira (Supervisão) [et al.], São Paulo: Instituto Nacional de Ciência e Tecnologia para Políticas Públicas de Álcool e Outras Drogas (INPAD), UNIFESP. 2014

KAMPMAN, K.M. What's new in the treatment of cocaine addiction? Curr Psychiatry Rep. Vol. 12, n. 5, p. 441-7, 2010.

KAPLAN, H.I; SADOCK, B.J. Substance related disorders. In: KAPLAN, H.I, SADOCK, B.J, Synopsis of Psychiatry: Behavioral Sciences/ Clinical Psychiatry. Baltimore: Williams \& Wilkins; 1998. P. 419-26.

KESSLER, F et al . Avaliação multidimensional do usuário de drogas e a Escala de Gravidade de Dependência. Rev. psiquiatr. Rio Gd. Sul, v. 32, n. 2,p.48-56, 2010. Disponível em: $<$ http://www.scielo.br/scielo.php?script=sci_arttext\&pid=S0101-

$81082010000200005 \& \operatorname{lng}=e n \& n r m=$ iso. Acesso em: 20 de outubro 2014.

KRUPSKI, A et al. Testing the effects of brief intervention in primary care for problem drug use in a randomized controlled trial: rationale, design, and methods. Addiction Science \& Clinical Practice, v.27, n.7, p.1-10, 2012.

LARANJEIRA R. et al. Seguimento de usuários de crack após dois anos. Rev Bras Psiquiatr. Vol.47, n.5, p. 233-6,1998.

LARANJEIRA, R. Tratamento da dependência do crack- as bases e os mitos. IN: RIBEIRO, M; LARANJEIRA, R. Tratamento do usuário de crack: Avaliação Clínica, psicossocial, neurológica e de risco. Terapias psicológicas, farmacoterapia e reabilitação. Ambientes de tratamento. São Paulo: Editora casa leitura Medica 2010. p. 15-23

LESHNER A.I. Using Behavioral Research to Address Drug Abuse and AIDS. AIDS and behavior, vol.2, n.3, p 263- 5, 1998.

MAGALHÃES, D. E, SILVA, M. R. S. Cuidados requeridos por usuários de crack internados em uma instituição hospitalar. reme - Rev. Min. Enferm,v.14,n.3,p. 408-15, 2010.

MARLATT, A.; GORDON, J. Prevenção de Recaída. Estratégias de manutenção no tratamento de comportamentos adictivos. Porto Alegre: Artes Médicas, 1993. 
MARLATT, G.A; WITKIEWITZ, K. Problemas com álcool e drogas. IN: MARLATT, G.A; DONOVAN, D. M. Prevenção de recaída. São Paulo: Artmed,,2009, p. 15-50.

MATHIAS, A.C. R; CRUZ ,M.S. Benefícios de técnicas cognitivo comportamentais em terapia de grupo para o uso indevido de álcool e drogas. J Bras Psiquiat, v. 57, n. 2, p. 1402. 2007.

MATSUKURA, T.S.;MARTURANO, E.M.; OISHI,J. O Questionário de Suporte Social (SSQ): estudos da adaptação para o português. Rev. Latino-Am. Enfermagem, vol.10, n.5, p. 675-81,2002.

MCKAY, J.R et al. Factors in sustained recovery from cocaine dependence. Journal of Substance Abuse Treatment, v. 45,n. 2. p. 163-72,2013.

MEDEIROS, P. F. P. et al. Um estudo sobre a avaliabilidade do Programa + Vida: política de redução de danos em álcool, fumo e outras drogas do município de Recife, Brasil. Rev. Bras. Saúde Matern. Infant., Recife, v.10 ;Supl. 1, p. 209-17, 2010.

MEIER, P.S et al. The role of the early therapeutic alliance in predicting drug treatment dropout. Drug alcohol depend.v.83, n.1, p. 57-64, 2006.

MILLER, W.R; HESTER, R.K. Treating alcohol problems: toward informed eclecticism. In: HESTER, R.K; MILLER, W.R. Handbook of alcoholism treatment approaches- effective alternatives. Boston: Allyn \& Bacon; 2003.

Ministério da saúde. Coordenação Nacional de Saúde Mental. Consultórios de Rua do SUS. Material de trabalho para a II Oficina Nacional de Consultórios de Rua do SUS. Ministério da Saúde/EPJN-FIOCRUZ, Brasília, 48f.,2010.

Ministério da Saúde. Secretaria de Atenção à Saúde. A política do ministério da saúde para a atenção integral a usuários de álcool e outras drogas. $2^{\mathrm{a}}$ ed. Brasília: Ministério da Saúde, 2004.

MINOZZI, S et al. Anticonvulsants for cocaine dependence. Cochrane Database Syst Rev. vol. 2, 2008 :CD006754.

MOURA, H.F et al . Crack/cocaine users show more family problems than other substance users. Clinics,v. 69, n. 7, p.497-99, $2014 \quad$. $\quad$ Disponível em: <http://www.scielo.br/scielo.php?script=sci_arttext\&pid=S1807-

59322014000700497\&lng=en\&nrm=iso >. Acesso em: 08 de outubro. 2014.

NAKATANI, A.Y.K. Processo de enfermagem: uma proposta de ensino através da pedagogia da problematizarão. 2000. P. 228 Tese (doutorado) - Universidade de São Paulo, escola de Enfermagem de Ribeirão Preto, São Paulo, 2000.

NATIONAL HEALTH SERVICE - national treatment agency of substance misuse. Care planning practice guide. London: $\mathrm{DH}$; 2006. Disponível em: < http://www.nta.nhs.uk/uploads/nta care planning practice guide $2006 \mathrm{cpg} 1 . \mathrm{pdf}$ > Acesso em: 07 de Setembro de 2013. 
NEVES, A.C.L; MIASSO, A.I. "Uma força que atrai": o significado das drogas para usuários de uma ilha de Cabo Verde. Rev. Latino-Am. Enfermagem.vol. 18, n. 2, p.159-68, 2010.

NONTICURI, A. R. As vivências de adolescentes e jovens com o crack e suas relações com as políticas sociais protetoras neste contexto. 2010.p. 144. Dissertação (Mestrado em Políticas Públicas) -Universidade Católica de Pelotas, Pelotas, 2010.

OLIVEIRA, G.P de. Crack e recaída: Os principais motivos que levam os usuários de crack a recaírem após tratamento para dependência química. 2010\2011.22f. Monografia (Conclusão parcial de especialização em saúde pública)- Universidade Federal do Rio Grande do Sul, escola de medicina, Rio Grande do Sul, 2011.

OLIVEIRA, L.G; NAPPO, S.A. Characterization of the crack cocaine culture in the city of the Sao Paulo: a controlled pattern of use. Rev Saúde Publica. Vol.42, n. 4, p.664-71, 2008. OPSAL, A et al. Factors associated with involuntary admissions among patients with substance use disorders and comorbidity: a cross-sectional study. BMC Health Services Research,v. 57, n. 13, 2013.

Organização Mundial de Saúde Glossário de álcool e drogas / Tradução e notas: BERTOLOTE, J. M. Brasília: Secretaria Nacional de Políticas sobre Drogas, 2010.

PASSOS, E.H, SOUZA, T.P. Redução de danos e saúde pública: construções alternativas à política global de "guerra às drogas". Psicologia \& Sociedade; v. 23,n.1, p. 154-162, 2011.

PATTON MQ. Qualitative research and evaluation methods. $3^{\text {a }}$ edição: Sage Publications, 2002, 598 p.

PAULA, M.L de et al . Usuário de crack em situações de tratamento: experiências, significados e sentidos. Saude soc., v. 23, n. 1, p. 118-130,2014. Disponível em: $<$ http://www.scielo.br/scielo.php?script=sci_arttext\&pid=S010412902014000100118\&lng=en\&nrm=iso>. Acesso em: 20 de outubro de 2014.

PEDROSO, R.S; KESSLER, F; PECHANSKY, F. Treatment of female and male inpatient crack users: a qualitative study. Trends Psychiatry Psychother., Porto Alegre , v. 35, n. 1, p.36-45 2013 Disponível em: $<$ http://www.scielo.br/scielo.php?script=sci_arttext\&pid=S2237$60892013000100005 \& \operatorname{lng}=$ en\&nrm=iso $>$. Acesso em 08 de outubro de 2014

Pesquisa Nacional sobre o uso de crack: quem são os usuários de crack e/similares do Brasil? Quantos são nas capitais brasileiras?/ organizadores: Francisco Inácio Bastos, Neiliane Bertoni- Rio de Janeiro: Editora ICICT/ FIOCRUZ, 2014.

PINHO, B.L et al. Consumo de crack: repercusiones en la estructura y en la dinámica de las relaciones familiares. Revista electrónica trimestral de enferméria., n. 25, p. 139- 49, 2012.

PRATTA, E.M.M; SANTOS, M.A dos. O processo saúde-doença e a dependência química: interfaces e evolução. Psic.: teor e pesq. V.25, n.2, p. 203-11, 2009. 
PROCHASKA, J. J; DELUCCHI, K; HALL, S. M. A meta-analysis of smoking cessation interventions with individuals in substance abuse treatment or recovery. Journal Of Consulting And Clinical Psychology,v. 72, n.6,p 1144-56,2004.

PROCHASKA, J.A; DICLEMENTE, C.C; NORCROSS, J.C. In search of how people chance: applications to addictive behaviour. AM PSYCHOL. sep, vol, 47, n. 09, p. 1102-14, 1992.

PULCHEIRO, G et al.Crack- da pedra ao tratamento. Revista as AMRIGS. Porto Alegre, v. 54, n. 3, p. 337- 43. 2010.

RANGÉ, B.P; MARLATT, G.A. Terapia cognitivo-comportamental de transtornos de abuso de álcool e drogas. Rev Bras Psiquiatr. v.30,Supl II, p.88-95, 2008.

RAUPP, L.M; MILNITISKY-SAPIRO, C. A "reeducação" de adolescentes em uma comunidade terapêutica: o tratamento da drogadição em uma instituição religiosa. Psic.: Teor. e Pesq., Brasília, v. 24, n. 3, p. 361-8, 2008. Disponível em: $<$ http://www.scielo.br/scielo.php?script=sci_arttext\&pid=S010237722008000300013\&lng=en $\& n r m=i s o>$. Acesso em: 08 de outubro de 2014.

RIBEIRO, $\mathrm{M}$ et al. Crack cocaine: a Five year follow-up study of treated patients. Eur. Addiction res., v. 13, n. 1, p. 11-9, 2007.

RIBEIRO, M; LARANJEIRA, R. O plano de tratamento. IN: RIBEIRO, M; LARANJEIRA, R. Tratamento do usuário de crack: Avaliação Clínica, psicossocial, neurológica e de risco. Terapias psicológicas, farmacoterapia e reabilitação. Ambientes de tratamento. São Paulo: Editora casa leitura Medica 2010. p. 24-63.

RIGOTTO, S.D; GOMES, W.B. Contextos de Abstinência e de Recaída na Recuperação da Dependência Química. Psic.: Teor. e Pesq., Brasília, v.18, n.1, p. 95 - 106 Jan-Abri. 2002.

RIZZINI, I; CASTRO, M.R., SARTOR C.D. - Pesquisando...Guia de metodologias de pesquisa para programas sociais. Rio de Janeiro: Editora Universitária Santa Úrsula, 1999.

RODRIGUES, D.S et al. Conhecimentos produzidos acerca do crack: uma incursão nas dissertações e teses brasileiras. Ciência \& Saúde Coletiva, v.17, n.5, p. 1247- 582012.

SABINO, N.D. M; CAZENAVE, S.O.S. Comunidades terapêuticas como forma de tratamento para a dependência de substâncias psicoativas. Estudos de Psicologia, v. 22, n. 2, p. 167-74, 2005.

SAKIYAMA, H.T; RIBEIRO, M. Prevenção de recaída e treinamento de habilidades sociais. IN: RIBEIRO, M; LARANJEIRA, R. Tratamento do usuário de crack: Avaliação Clínica, psicossocial, neurológica e de risco. Terapias psicológicas, farmacoterapia e reabilitação. Ambientes de tratamento. São Paulo: Editora casa leitura Medica 2010. p. 229- 47

SANCHEZ, Z.V.M; NAPPO, S.A. Sequência de drogas consumidas por usuários de crack e fatores interferentes. Rev. Saúde Pública, v.36, n.4, p. 420-30,2002. 
SCHEFFER, M; PASA, G.G; ALMEIDA, R.M.M de. Dependência de álcool, cocaína e crack e transtornos psiquiátricos. Psic.: Teor. e Pesq. v. 26, n. 3, p.533-41; 2010. Disponível em: $<$ http://www.scielo.br/scielo.php?script=sci_arttext\&pid=S0102-

37722010000300016\&lng=en\&nrm=iso. Acesso em: 08 de outubro de 2014.

SELEGHIM, M.R; OLIVEIRA, M.L.F de. Influência do ambiente familiar no consumo de crack em usuários. Acta paul. enferm. v. 26, n. 3,p. 263-68, 2013 . Disponível em: <http://www.scielo.br/scielo.php?script=sci_arttext\&pid=S0103-

21002013000300010\&lng=en\&nrm=iso>. Acesso em: 20 de Outubro de 2014.

SILVA JUNIOR, F.J.G; MONTEIRO, C.F.S. Os significados da morte e do morrer: a perspectiva de usuários de crack. Rev. Latino-Am. Enfermagem, vol. 20, n. 2, p. 1-6, 2012.

SILVA, C.J; SERRA, A.M. Terapias cognitiva e cognitiva- comportamental em dependência química. Rev. Bras Psiquiatria, v. 26, supl 01, p. 33-9. 2004.

SILVA, E.F et al.Caracterização do consumo de drogas ilícitas entre escolares do ensino médio. Arq Ciên saúde, v. 14, n. 3, p. 135-9, 2007.

SILVA, L.H.P et al. Perfil dos dependentes químicos atendidos em uma unidade de reabilitação de um hospital psiquiátrico. Rev Enferm. v. 14, n. 3. p. 585-90, 2010.

SILVEIRA, D.X da. Drogas: uma compreensão psicodinâmica das farmacodepêndencias. 3 ed. São Paulo: Casa do Psicólogo, 80p.1995.

SINHA, R., LI, C. S. Imaging stress- and cue-induced drug and alcohol craving: Association with relapse and clinical implications. Drug and Alcohol Review v. 26, n. 1,p. 25-31, 2007.

TARDY, C.H. Social Support Measurement. American Journal of Community Psychology, v. 13, n. 2, p. 187-202, 1985.

TAYLOR, S.J; BODGAN, R. Introduction to Qualitative Research Methods. NewYork: John Wiley \& Sons Inc., 1998; 337 p.

TRIVIÑOS, A.N.S. Alguns temas no desenvolvimento de uma pesquisa. IN: TRIVIÑOS, A.N. S. Introdução à pesquisa em ciências sócias: a pesquisa qualitativa em educação. São Paulo: Editora Atlas, 1987. p. 91- 114.

TURATO, E.R. Métodos qualitativos e quantitativos na área de saúde: definições, diferenças e seus objetivos de pesquisa. Rev saúde Pública. V. 39, n. 3, p. 507-14, 2005.

UNITED NATIONS OFFICE ON DRUGS AND CRIME .World Drug Report 2014: United Nations Publication, 2014. Disponível em: <http://www.unodc.org/documents/wdr2014/World_Drug_Report_2014_web.pdf > acesso em: 17 de março de 2013.

VARGENS, R.W; CRUZ, M.S; SANTOS, M.A dos. Comparação entre usuários de crack e de outras drogas em serviço ambulatorial especializado de hospital universitário. Rev. Latino-Am. Enfermagem, vol, 19,n.spe, p. 804- 12, 2011. 
VAUX, A. Social support: theory, research and intervention . New York: Prager, 1988.

VELOSO, L.; CARVALHO, J; SANTIAGO, L. Redução de danos decorrentes do uso de drogas: uma proposta educativa no âmbito das políticas públicas. In: Bravo M.I.S, Saúde e serviço social. São Paulo: Cortez; Rio de Janeiro: UERJ; 2004.

VIVES, J.F; GARCÍA, C.S; BALSA, M.C.C. Organizacíon y registro de La infomación. Uma propuesta según patrones de salud. IN: VIVES, J.F; C.S; BALSA. Enfermería de salud mental y psiqiátrica. Madrid: Médica Panamericana, 2001, p. 47- 113.

WECHSBERG, W.M et al. African-American crack abusers and drug treatment initiation: barriers and effects of a pretreatment intervention. Substance Abuse Treatment, Prevention, and Policy, v.10, n.2,p. 25-31, 2007.

WEINBERGER, A. H.; SOFUOGLU, M. The impact of cigarette smoking on stimulant addiction. American Journal of Drug and Alcohol Abuse, v.35,n.1,p. 12-7,2009.

WEISS, R. et al. The relationship between cocaine craving, psychosocial treatment, and subsequent use. American Journal of Psychiatry, v. 160, n. 7 p.1320-5,2003.

WENDT, N.C; CREPALDI, M.A. A Utilização do genograma como instrumento de coleta de dados na pesquisa qualitativa. Psicol. reflex. Crit., v.21, n.2, p.302-10. 2008.

WHO- World health organization neuroscience of psychoactive substance use and dependence. Geneve: WHO; 2004. Disponível online em: HTTP: // www. Who.int.

WITKIEWITZ, K. et al. Mindfulness-based relapse prevention for substance craving. Addictive Behaviors, vol.38, p. 1563-71, 2013.

YOUNG, M.M et al. Effectiveness of brief interventions as part of the screening, brief intervention and referral to treatment (SBIRT) model for reducing the non-medical use of psychoactive substances: a systematic review protocol. Systematic Reviews. v.50, n. 3, 2012.

YOUNG, R; WEST, P. D o ' $\mathrm{g} \quad \mathrm{o}$ o d values' lead to 'good' health-behaviours? Longitudinal associations between young people's values and later substance-use. BMC Public Health,v. 165, n. 10, 2010.

ZENI T. C de; ARAUJO, R. B. Relação entre craving por crack em pacientes internados por desintoxicação. J. Bras. Psiquiat, v.60, n. 1, p.28-33, 2011. 


\section{APÊNDICES}

\section{APÊNDICE A: TERMO DE CONSENTIMENTO LIVRE E ESCLARECIDO}

Prezado Senhor (a),

Eu, Camila Souza de Almeida, enfermeira e mestranda pela Escola de Enfermagem de Ribeirão Preto - USP, gostaria de convida-lo a participar de uma pesquisa que estou desenvolvendo intitulada como "Determinantes intrapessoais e interpessoais no processo de recaída em usuários de cocaína/crack”, sob orientação da Prof ${ }^{a} \operatorname{Dr}^{a}$ Margarita Antonia Villar Luis, do departamento de enfermagem Psiquiátrica e Ciências Humanas - EERP- USP. O projeto tem como finalidade analisar os fatores que podem influenciar na volta ao uso de cocaína/ crack, visando assim, aumentar o conhecimento para propor programas ou técnicas de intervenção a serem implementados pela enfermagem no âmbito hospitalar e comunitário.

Para obter esses dados, você está sendo convidado a participar em um primeiro momento de uma entrevista, com duração média de 30 minutos, que será gravada e a aplicação de dois testes de múltipla escolha sobre o tema. A entrevista e a aplicação dos instrumentos serão previamente agendadas, tento sem vista a sua disponibilidade. Você será convidado a participar de um grupo de reflexão sobre cuidados em saúde no CAPS ad de Itaúna, em data a ser agendada e confirmada. Esse grupo terá a duração de 5 semanas, com encontros semanais de no máximo duas horas, em que as falas e discussões serão gravadas para analise, os dias do encontro e o tempo médio serão discutidos com todos os participantes previamente. O participante poderá recusar a participar dos encontros, assim como desistir desses durante o processo. Posteriormente, após três meses dessa primeira entrevistas, gostaríamos de agendar novos encontros, em local(s) de sua preferência para uma nova entrevista de 30 minutos e a aplicação dos mesmos testes. Em caso de desconforto durante as questões apresentadas durante a entrevista, o participante poderá se recusar a responder ou interrompe-la. Asseguramos que as informações fornecidas serão sigilosas e utilizadas para fins de ensino e pesquisa. Uma via assinada deste Termo lhe será entregue e a outra será seguramente arquivada juntamente com o material coletado da pesquisa, sem qualquer tipo de prejuízo pessoal, despesa ou gratificação. Estará garantido o direito de esclarecimento de eventuais dúvidas antes, durante e após o desenvolvimento deste trabalho. O participante da pesquisa tem direito à indenização, conforme as leis vigentes no país caso ocorra dano decorrente da sua participação na pesquisa. Além da liberdade de negar-se a continuar participado, caso julguem necessário, sem sofrer qualquer dano em qualquer momento da pesquisa. 
Antecipadamente, agrademos sua colaboração.

$\mathrm{Eu}$, concordo em participar voluntariamente da pesquisa e afirmo que fui convidado e esclarecido de que receberei resposta para qualquer pergunta ou dúvida que possa surgir durante a pesquisa, Estou ciente de que, em nenhum momento, serei identificado nem exposto a riscos devido a minha participação nesta pesquisa. Sei também que, a qualquer momento poderei recusar-me a continuar, sem qualquer prejuízo para a minha pessoa. Fui informado que não terei nenhum tipo de despesa, nem receberei nenhuma gratificação ou pagamento pela minha participação nesta pesquisa. Concordo, voluntariamente, em participar deste estudo.

Em caso de dúvidas ou necessidade de entrar em contato, estaremos disponíveis para esclarecimentos assim como o comitê de ética em pesquisa com seres humanos (CEP) da Escola de Enfermagem de Ribeirão Preto- USP. Seguem-se os contatos

Camila Souza de Almeida (pesquisadora)

Csalmeida 1@hotmail.com

Telefone: (37) 98335592
Margarita Antônia Villar Luis( orientadora) margarit@eerp.usp.br

Telefone: (16) 3602-3381

Comitê de ética em pesquisa com seres humanos ( CEP) da Escola de Enfermagem de Ribeirão PretoUSP

Funcionamento: segunda a sexta, das $8 \mathrm{~h}$ às $17 \mathrm{~h}$.

Telefone (16) 3602-3386

Itaúna, Minas Gerais, de de

Assinatura do pesquisar

$$
\mathrm{N}^{\mathrm{o}}-\mathrm{RG}
$$

Assinatura do participante

$\mathrm{N}^{\mathrm{o}} \mathrm{RG}$ 


\section{APÊNDICE B: ROTEIRO ENTREVISTA: FATORES INTERPESSOAIS}

1. Apoio social (TARDY, 1985; VAUX, 1988).

\begin{tabular}{|c|c|c|c|}
\hline & $\begin{array}{l}\text { Direção do apoio } \\
\text { De quem recebe apoio? }\end{array}$ & $\operatorname{Sim}(\quad)$ & Não ( \\
\hline 1.2 & $\begin{array}{l}\text { Disposição } \\
\text { Como você utiliza esse apoio? Você o leva em consideração? }\end{array}$ & $\operatorname{Sim}(\quad)$ & Não ( \\
\hline 1.3 & $\begin{array}{l}\text { Descrição } \\
\text { Que tipo de apoio recebe? } \\
\text { a) Conselhos/ orientações } \\
\text { b) Abrigo (compartilha moradia, espaço para viver). }\end{array}$ & $\operatorname{Sim}(\quad)$ & Não ( \\
\hline & c) Financeiro & $\operatorname{Sim}(\quad)$ & Não ( \\
\hline & d) Alimentação & $\operatorname{Sim}(\quad)$ & Não ( \\
\hline & e) Vestimenta & $\operatorname{Sim}(\quad)$ & Não ( \\
\hline & f) Auxilio no tratamento & $\operatorname{Sim}(\quad)$ & Não ( \\
\hline & g) Manifestações de afeição (simpatia, carinho, estima) & $\operatorname{Sim}(\quad)$ & Não ( \\
\hline & $\begin{array}{l}\text { h) Reforço na tomada de decisões (parar de usar, cuidar mais de si } \\
\text { mesmo) }\end{array}$ & $\operatorname{Sim}(\quad)$ & Não ( \\
\hline $\begin{array}{l}2 . \\
\text { a) } \\
\text { b) } \\
\text { c) } \\
\text { d) }\end{array}$ & $\begin{array}{l}\text { Suporte Social (Embasado no SSQ) } \\
\text { Com quais pessoas você pode contar para ouvi-lo independentemente da } \\
\text { situação que você está vivenciando? } \\
\text { Com que você pode contar para ajuda-lo a sair de uma crise? Seja ela } \\
\text { qual for? } \\
\text { Com quem você pode ser apenas você mesmo? } \\
\text { Quem pode ajuda-lo a se acalmar quando está irritado ou ansioso com } \\
\text { algo? }\end{array}$ & & \\
\hline 3. & $\begin{array}{l}\text { Como avalia esse apoio } \\
\text { a) } \mathrm{O} \text { apoio que você recebe o ajuda a mudar? A repensar suas } \\
\text { atitudes? }\end{array}$ & $\operatorname{Sim}(\quad)$ & Não ( \\
\hline & $\begin{array}{l}\text { b) Ajuda apenas a mudar momentaneamente, mas a longo prazo não } \\
\text { surte efeito? }\end{array}$ & $\operatorname{Sim}(\quad)$ & Não ( \\
\hline & c) Estimula a fazer mudanças e o ajuda a dar continuidade nesse & $\operatorname{Sim}(\quad)$ & Não ( \\
\hline
\end{tabular}




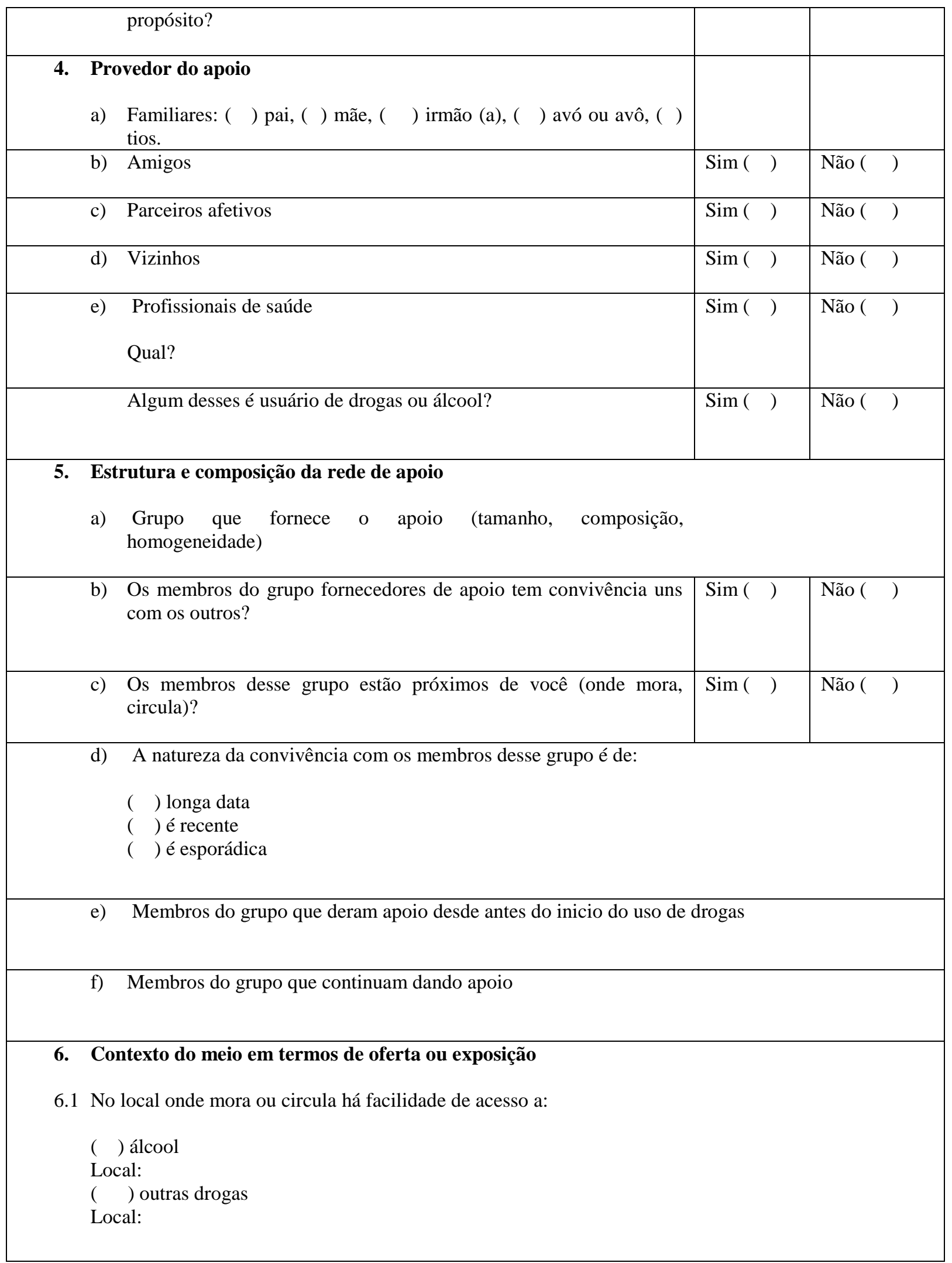




\section{APÊNDICE C: ROTEIRO DE ENTREVISTA: FATORES INTRAPESSOAIS (MARLATT; WITKIEWITZ, 2009)}

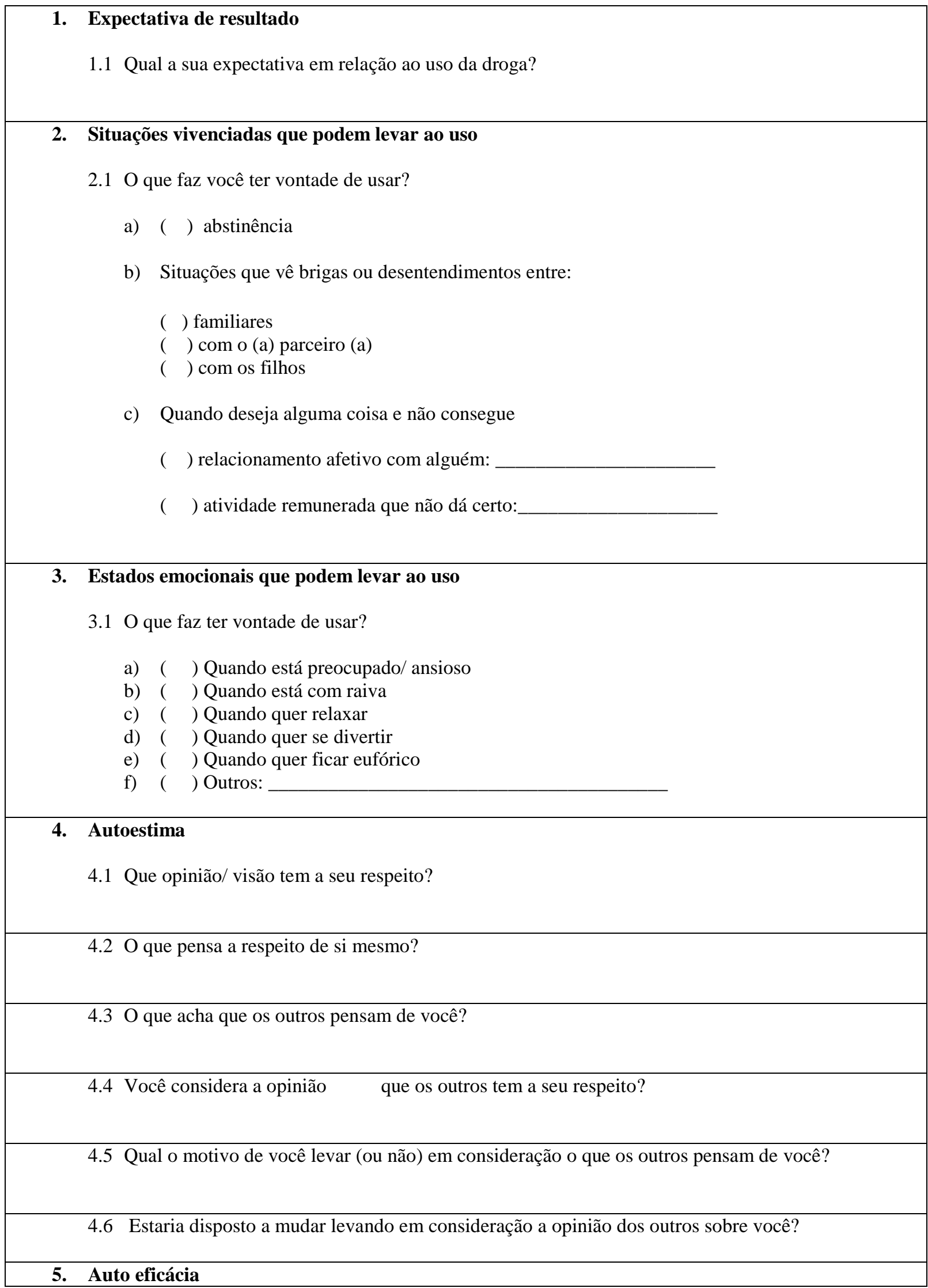


5.1 O que em sua opinião dificulta o controle do uso de drogas?

5.2 O que em sua opinião facilita o controle do uso de drogas?

5.3 Você pensa na possibilidade de não mais fazer o uso?

6. Enfrentamento ( VIVES; GARCÍA; BALSA, 2001)

6.1 Se sente capacitado (com forças, recursos) para controlar as situações (emocionais, afetivas) que provocam o desejo de uso de drogas/ álcool?

6.2 Sabe como fazer para contornar essas situações que provocam o desejo?

6.3 Qual tem sido a resposta habitual quando está ansioso, preocupado ou nervoso?

6.4 O que faz para se acalmar?

6.5 Tem tido êxito em suas respostas de adaptação as situações de desejo pelo uso de drogas?

6.6 Considera saudáveis essas respostas?

6.7 Quais outras condutas você colocaria em seu repertorio de enfrentamento a esse desejo? 
Nome do Entrevistador:

Data da Entrevista:

I- Identificação

Iniciais do nome:

Idade:

Dados Gerais

\begin{tabular}{|c|c|c|}
\hline 1 & $\begin{array}{l}\text { Idade } \\
\text { (1) Menor ou igual a } 19 \text { anos } \\
\text { (2) } 20 \text { a } 29 \text { anos } \\
\text { (3) } 30 \text { a } 39 \text { anos } \\
\text { (4) } 40 \text { ou mais }\end{array}$ & ( ) \\
\hline 2. & $\begin{array}{l}\text { Escolaridade } \\
\text { (1) Não alfabetizada } \\
\text { (2) Ensino fundamental incompleto } \\
\text { (3) Ensino fundamental completo } \\
\text { (4) Ensino médio incompleto } \\
\text { (5) Ensino médio completo } \\
\text { (6) Ensino superior }\end{array}$ & $($ ) \\
\hline 3. & $\begin{array}{l}\text { Estado Civil } \\
\text { (1) Solteiro (a) } \\
\text { (2) Casado (a) } \\
\text { (3) Mora com o companheiro (a) } \\
\text { (4) Outros }\end{array}$ & $($ ) \\
\hline 4. & $\begin{array}{l}\text { Raça/cor } \\
\text { (1) Branca } \\
\text { (2) Negra } \\
\text { (3) Parda } \\
\text { (4) Amarela/ Indígena }\end{array}$ & $($ ( ) \\
\hline 5. & $\begin{array}{l}\text { Fonte de renda } \\
\text { (1) Alguma fonte de renda } \\
\text { (2) Desempregado }\end{array}$ & $($ ) \\
\hline 6. & $\begin{array}{l}\text { Tipo de moradia atual } \\
\text { (1) Casa ou apartamento } \\
\text { (2) Abrigo público ou nas ruas } \\
\text { (3) Favela } \\
\text { (4) Cortiço/ pensão }\end{array}$ & $($ ( ) \\
\hline 7. & $\begin{array}{l}\text { Religião/ crença } \\
\text { (1) Católica } \\
\text { (2) Protestante } \\
\text { (3) Espírita }\end{array}$ & $($ ) \\
\hline
\end{tabular}




\begin{tabular}{|l|l|c|}
\hline & $\begin{array}{l}\text { (4) Ateu } \\
\text { (5) outras: }\end{array}$ & \\
\hline 8. & $\begin{array}{l}\text { Número de recaídas } \\
\text { (1) } 1-3 \text { episódios } \\
\text { (2) } 4-5 \text { episódios } \\
\text { (3) }>5 \text { episódios }\end{array}$ & \\
\hline
\end{tabular}

\section{Frequência de uso de cocaína/ crack e outras drogas}

\begin{tabular}{|l|l|l|}
\hline 8. & $\begin{array}{l}\text { Crack } \\
\text { (1) Uso diário } \\
\text { (2) Uso semanal } \\
\text { (3) Uso mensal } \\
\text { (4) Não está em uso a mais de três semanas } \\
\text { (5) Não Faz o uso }\end{array}$ & \\
\hline 9. & $\begin{array}{l}\text { Cocaína } \\
\text { (1) Uso diário } \\
\text { (2) Uso semanal } \\
\text { (3) Uso mensal } \\
\text { (4) Não está em uso a mais de três semanas } \\
\text { (5) Não Faz o uso }\end{array}$ & \\
\hline 10. & $\begin{array}{l}\text { Álcool } \\
\text { (1) Não usa } \\
\text { (2) Uso diário } \\
\text { (3) Uso semanal } \\
\text { (4) Esporádico }\end{array}$ & \\
\hline 11. & $\begin{array}{l}\text { Tabaco } \\
\text { (1) Não usa } \\
\text { (2) Uso diário } \\
\text { (3) Uso semanal } \\
\text { (4) Esporádico }\end{array}$ & \\
\hline 12. & $\begin{array}{l}\text { Maconha } \\
\text { (1) Não usa } \\
\text { (2) Uso diário } \\
\text { (3) Uso semanal } \\
\text { (4) Esporádico }\end{array}$ & \\
\hline
\end{tabular}


ANEXO

ANEXO 1- AUTORIZAÇÃO DA EER/USP PARA A REALIZAÇÃO DA PESQUISA

\section{ESCOLA DE ENFERMAGEM DE Plotoforma RIBEIRÃO PRETO - USP}

\section{PARECER CONSUBSTANCIADO DO CEP}

\section{DADOS DO PROJETO DE PESQUISA}

Título da Pesquisa: Determinantes intrapessoais e interpessoais no processo de recaída em usuários de cocaina/crack

Pesquisador: Camila Souza de Almeida

Área Temática:

Versāo: 3

CAAE: 19403913.2 .0000 .5393

Instituição Proponente: Escola de Enfermagem de Ribeirão Preto - USP

Patrocinador Principal: Financiamento Próprio

\section{DADOS DO PARECER}

Número do Parecer: 553.945

Data da Relatoria: 12/02/2014

Apresentação do Projeto:

Trata-se do mesmo projeto, porém com alteraçâo do local de realizaçăo do mesmo.

Objetivo da Pesquisa:

Trata-se do mesmo projeto.

Avaliação dos Riscos e Beneficios:

Trata-se do mesmo projeto.

Comentários e Consideraçōes sobre a Pesquisa:

As pesquisadoras referem que foi necessário a emenda devido a năo adequação do local em que estava sendo realizada a pesquisa e o objetivo do estudo, devido a necessidade de acompanhamento dos pacientes usuários de crack por três meses, mas esses devem estar inseridos na sociedade e no Hospital psiquiátrico os tratamentos estăo sendo

fechados e com tempo maior do que três meses. Além de que o novo local é no Estado de Minas Gerais local em que mora a pesquisadora.

Consideraçōes sobre os Termos de apresentação obrigatória:

TCLE encontra-se de acordo com a Resoluçāo 466/12 da CNS/MS e já foi aprovado por este CEP em novembro de 2013. As pesquisados encaminharam a carta de autorização da CAPS-ad de

Endereço: BANDEIRANTES 3900

Bairro: VILA MONTE ALEGRE

UF: SP Município: RIBEIRAO PRETO

Telefone: (16)3602-3386

E-mail: cep@eerp.usp.br 


\section{ESCOLA DE ENFERMAGEM DE RIBEIRÃO PRETO - USP}

Continuaģa do Parecer: 553.945

Itaúna, aprovando a realização do projeto. E enviaram também carta solicitando a este CEP emenda de alteraçåo do projeto. apresentado novo cronograma.

\section{Recomendaçōes:}

Não há.

Conclusōes ou Pendências e Lista de Inadequações:

As pesquisadoras apresentaram os termos necessários para que a alteraçăo fosse realizada.

Situaçāo do Parecer:

Aprovado

Necessita Apreciação da CONEP:

Não

Considerações Finais a critério do CEP:

Parecer apreciado na 176a reunião ordinária.

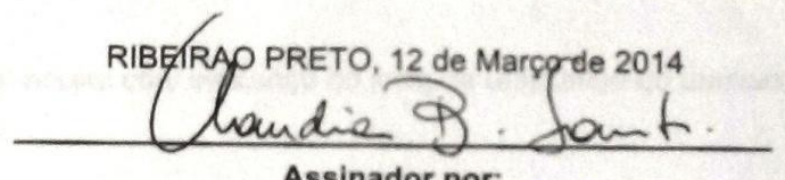

Assinador por:

Claudia Benedita dos Santos

(Coordenador) 
ANEXO 2- AUTORIZAÇÃO DO CAPS II DE ITAÚNA

\section{Declaração}

O Centro de Atenção Psicossocial Álcool e outras Drogas (CAPS_ad) da cidade de Itaúna, Minas Gerais, por meio da Diretora de Saúde Mental e do Coordenador do CAPS_ad da Cidade, declara que, o projeto de pesquisa de autoria da Mestranda Camila Souza de Almeida, intitulado: “ Determinantes intrapessoal e interpessoal no processo de recaída em usuários de crack/ cocaína" foi analisado e autorizado pela comissão de ética do CAPS_ad.

Itaúna, 02 de Dezembro de 2013

An Oliverio

Ivete A. de Miranda Oliveira

Diretora de Saúde Mental Itaúna

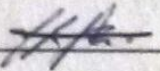

Carlos Roberto dos Santos

Coordenador do CAPS_ad Itaúna 